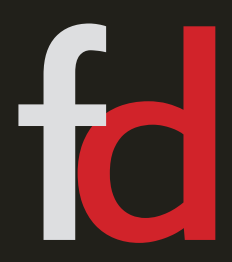

ČASOPIS

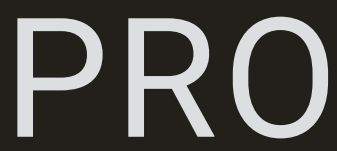

SOUČASNOU

FILOSOFII

ČíSLO 2

ROČNÍK 12

2020 


\section{FILOSOFIE DNES}

Časopis pro současnou filosofii vydává KFSV FF UHK

\section{Šéfredaktor: Ladislav Koreň}

\section{Výkonná redaktorka: Iva Svačinová}

Redakční rada: Ondřej Beran, Jaroslav Daneš, Petr Glombíček, Tomáš Hirt, Juraj Hvorecký, Vojtěch Kolman, Ladislav Kvasz, Róbert Maco, Tomáš Marvan, Martin Paleček, Jaroslav Peregrin, Marie Hrdá, Ondřej Švec, Eugen Zeleňák

Editoři: Markéta Panoušková, Hynek Kaplan Sazba a grafická úprava: Hynek Kaplan

Adresa: Filosofie dnes, KFSV FF UHK Rokitanského 62 50003 Hradec Králové

E-mail: iva.svacinova@uhk.cz

vychází elektronicky, dvakrát ročně

www.filosofiednes.ff.uhk.cz

ISSN 1804-0969

Ročník 12, Č́́slo 2 (2020) 


\section{Obsah}

\section{Studie}

Kristýna Vozková José Ortega y Gasset a hispanoamerické filo3 sofické myšlení

Kristina Vejnbender Uplatnění pozdní filozofie L. Wittgensteina v myšlení C. Geertze

\section{Zprávy}

Lukáš Mareš

Filosofická praxe v České republice

Václav Peltan

Eliška Havlová

\section{Recenzní studie}

Jan Géryk

Politickofilosofický úklid v čase plurality

a zběsilé strnulosti.

Nad knihou Pavla Dufka, Jiř́ho Baroše,

Sylvie Bláhové, Terezy Křepelové a Patrika

Taufara Liberální demokracie $v$ době krize:

Perspektiva politické filosofie

Daniel D. Novotný Covid-19 katastrofa: Nad knihou Richarda Hortona 


\title{
José Ortega y Gasset a hispanoamerické filosofické myšlení
}

\author{
Kristýna Vozková \\ Filozofická fakulta \\ Západočeská univerzita \\ Univerzitní 2732/8, 30100 Plzeň \\ kvozkova@kfi.zcu.cz
}

Předložená studie pojednává o tom, jakým způsobem ovlivnily země Latinské Ameriky myšlení významného španělského moderního filosofa Josého Ortegy y Gasseta, a rovněž o pocitech, které $\mathrm{v}$ autorovi zanechaly jeho návštěvy Argentiny. Dále se zaměřuje na vliv Ortegy na hispanoamerické filosofické myšlení. Na prvních stránkách text představuje stručnou historii filosofického myšlení v Latinské Americe. Následně se zaměřuje na Ortegovu snahu o nalezení intelektuálního „éku“ na hispanoamerický problém spojený s hledáním národní identity. Dále přibližuje Ortegovy myšlenky, teorie a koncepce, které měly nejvýznamnější vliv na tvorbu tamních intelektuálů, zejména teorii okolností, perspektivismus, raciovitalismus, teorii generací a teorii kultur.

Klíčová slova: José Ortega y Gasset, hispanoamerické filosofické myšlení, Latinská Amerika, Ortega a Argentina, Ortega a Hispanoamerika, národní identita, okolnosti, perspektivismus, raciovitalismus

José Ortega y Gasset bývá mnohými označován za jednoho z nejvýznamnějších španělských myslitelů 20. století. Svými příspěvky na poli filosofie, sociologie, antropologie, politologie a estetiky ovlivnil celou řadu autorů ve svém rodném Španělsku i za jeho hranicemi, zejména v Latinské Americe. Významného vlivu se Ortegova filosofie dočkala především v Argentině, kterou autor navštívil poprvé již v roce 1916, kdy se zde společně se svým otcem účastnil půlročního přednáškového cyklu na uni- 
verzitě v Buenos Aires. Od té doby kontinent ${ }^{1}$ navštívil ještě několikrát a k jeho zemím si vybudoval silné intelektuální pouto.

Již po první návštěvě Argentiny začala vznikat řada studií, esejů a komentářo hodnotících hispanoamerické země a jejich kulturu. Většina $\mathrm{z}$ nich byla o čtrnáct let později vydána $\mathrm{v}$ souhrnném díle s názvem $\mathrm{Me}$ ditace o mladém národě a jiné eseje o Americe (Meditación del pueblo joven y otros ensayos sobre América), které obsahovalo texty s touto tematikou z období mezi roky 1916-1940.²

Reflexe Ortegovy filosofie mají na americkém kontinentě dlouholetou tradici. Vstřícně zde byly přijímány zejména myšlenky, které nejvíce korespondovaly se situací, v níž se země Latinské Ameriky nacházely. Ortegova raná tvorba hojně reflektovala sociální situaci, která zavládla na počátku 20. století ve Španělsku. V roce 1898 ztratila země značnou část svých významných kolonií a její mocenský úpadek s sebou nesl i další důsledky na poli ekonomie, kultury nebo vzdělávání. ${ }^{3}$ Tato „koloniální katastrofa“ vyvolala v intelektuálních kruzích otázky směřující k podstatě španělského národa, postavení země v dějinách a jejímu dalšímu směřování. Byla rovněž impulsem pro vznik Generace 98, intelektuálního uskupení usilujícího o reflexi a řešení tohoto „španělského problému“.. José Ortega y Gasset, člen nastupující Generace 14, tuto starost po svých předchůdcích převzal a snažil se nalézt východisko z krize a abídnout „lék“, který by vlasti opět vrátil její někdejší slávu. A právě tyto myšlenky, spojené úzce s národní identitou, byly hispanoamerickými mysliteli vnímány jako inspirace a nástroj použitelný při řešení problémů jednotlivých zemí.

\section{Hispanoamerické filosofické myšlení}

Následující kapitola přiblíží čtenáři charakteristické rysy i stručný vývoj moderního hispanoamerického filosofického myšlení, pro něž byl od

1 Ortega navštívil kontinent celkem čtyřikrát. První tři návštěvy směřoval do Argentiny, tu poslední, nejkratší, do Spojených států amerických (1949). Během svého prvního pobytu v Argentině (1916-1917) navštívil krátce také Uruguay, během toho druhého (1928-1/1929) zavítal do Chile. V Argentině následně prožil roky 1939 až 1942. Gomez-Martinez (1983, 128-131).

2 Housková (2006, s. 17).

3 Forbelský (1999, s. 30).

4 Černá (2012, s. 235). 
počátku typický silný př́íklon $\mathrm{k}$ myšlení evropskému. Celá řada filosofických koncepcí byla - stejně jako v případě filosofie španělské - odvozena od myšlenek významných evropských myslitelů, a to do té míry, že jedním ze zásadních témat pro mnoho autorů bylo tázání se po originalitě a autenticitě latinskoamerické filosofie, ba dokonce po její samotné existenci.

Moderní latinskoamerická filosofie bývá spojována s počátkem 19. století, kdy se oblast definitivně vymanila z vlivu evropských koloniálních sil. Stejně jako v evropské filosofii se i zde projevoval silný vliv pozitivismu, přetrvávající přibližně do první dekády 20. století, společně se snahou o budování sociální a ekonomické stability. Od 30. let 20. století se však nastupující generace autorů vůči pozitivismu století předchozího začala ostře vymezovat. Jejich inspiračními zdroji byli francouzští a němečtí myslitelé a do tamějšího myšlení začal pronikat existencialismus, fenomenologie nebo vitalismus. ${ }^{5}$ Patrně nejdiskutovanějším tématem se tak v latinskoamerické filosofii 20. století stala existence hispanoamerického filosofického a vědeckého myšlení, odhalování jeho charakteristických rysů a pátrání po kořenech. Tedy témata ne nepodobná debatám, které probíhaly ve Španělsku a jejichž problematika bývá spojována již se 16. stoletím a tzv. černou legendou, tedy šířením negativních názorů týkajících se španělského národa a jakýmsi zpochybňováním jeho významu v evropských intelektuálních dějinách. ${ }^{6}$

Již od konce 19. století autoři jako Domingo Faustino Sarmiento (1811-1888) nebo Juan Bautista Alberdi (1810-1884) publikovali statě zabývající se problematikou civilizačního procesu. O hispanoamerické kultuře, její identitě a hodnotách pojednává také esej Naše Amerika (Nuestra América) z roku 1891. Jeho autor, José Martí (1853-1895), v něm hovoří o Americe jako o „nemocné matce, kterou její děti opouštějí místo

5 Gracia \& Vargas (2018, s. 4).

6 Roku 1782 označil Nicolas Masson de Morvilliers (1740-1789) v díle Encyclopédie Métodique Španělsko za nejzaostalejší národ v celé Evropě, jeho obyvatele za nevzdělance a španělskou vědu za neexistující. Kniha vyvolala ve Španělsku značnou vlnu nevole a byla impulzem pro zahájení diskuze označované jako „polemika o španělské vědě“. Následovala celá řada apologií a pojednání o významu Španělska v evropských dějinách. Ve 2. polovině 19. a na počátku 20. století byly spory o význam země v evropských dějinách motivovány rovněž politicky. Docházelo zde ke střetům mezi moderními progresisty a umírněnými tradicionalisty, a názory obou táborů byly natolik nesmiřitelné, že se hovoří o tzv. „dvojím Španělsku“ („dos Españas“). Černá (2012, s. 240). 
toho, aby se ji pokusili vyléčit“.7 Volá po její záchraně a vytvoření „nové Ameriky“ postavené na uvědomění si specifik vlastních zemí, osvobození od tyranie a důrazu na tvưrčí činnost. ${ }^{8}$

Během 20. století se úvahami o hledání vlastní identity a zkoumáním odlišných i společných rysů hispanoamerických zemí zabývali například Francisco Miró Quesada Cantuarias (1918-2019), Eduardo García Maynez (1908-1993) nebo Risieri Frondizi (1910-1985). Tito autoři nastolili tradici filosofického dialogu mezi autory různých zemí a začali opětovně pracovat s konceptem „hispanity“9, který představil již Miguel de Unamuno (1864-1936). ${ }^{10}$ Dílem, které po několik dekád inspirovalo úvahy o hispanoamerické filosofii, byl rovněž text s názvem Panorama de las ideas filosóficas en Hispanoamérica, jehož autorem je Aníbal Sánchez Reulet (1910-1997) a který byl publikován roku 1936 v časopisu Tierra Firme. Mezi autory, kteří k debatám o existenci hispanoamerické filosofie přispěli patrně nejvýrazněji, patří Leopoldo Zea (1912-2004) a Samuel Ramos (1897-1959). Zea svými texty jako América Latina: historia y destino: homenaje a Leopoldo Zea (1992) nebo América Latina en sus ideas (1986), Ramos pak zejména knihami Historia de la filosofía en México (1943) a El perfil del hombre y la cultura en México (1938). ${ }^{11}$ Všichni zmínění autoři hojně pracovali s termíny jako existence, identita, originalita, autenticita a charakteristické rysy. Kromě Ortegy byli za významné inspirátory tohoto období považováni také Edmund Husserl (1859-1938), Wilhelm Dilthey (1833-1911), Max Scheler (1874-1928) nebo Nicolai Hartmann (1882-1950). ${ }^{12}$

Do vývoje intelektuálního myšlení v Latinské Americe se úzce promítala také politická situace v jednotlivých zemích. Časté státní zásahy do oblastí vzdělání a vědy vedly mnoho autorů k odchodu do exilu. Naopak během občanské války ve Španělsku do oblasti přišla řada španělských emigrantů, kteří byli pro zdejší intelektuální oblast velkým přínosem.

7 Martí (1891, s. 134).

8 Tamtéž, s. 137-139. Martí se zabýval otázkami moderní doby i v dalších textech, viz např. Poláková (2017, s. 13-14).

9 Termín odkazující ke sdílení španělského jazyka i kultury v rámci různých zemí i komunit.

10 Serna (2020, s. 174).

11 Gracia \& Vargas (2018, s. 10).

12 Tamtéž, s. 9. 
Můžeme zde zmínit jména jako jsou José Ferrater Mora (1912-1992), José Gaos (1900-1969), Juan David García Bacca (1901-1992), Joaquin Xirau (1895-1946) nebo María Zambrano (1904-1991). Díky četné migraci mezi autory se tak začaly myšlenky šiřit i za hranice jednotlivých národů. Každý $\mathrm{z}$ nich $\mathrm{s}$ sebou přinesl část vlastní kultury a napomohl k budování specifického multikulturního klimatu. ${ }^{13}$ Díla, která vznikala v zemích Hispanoameriky ve 20. století, tak byla na jedné straně odvozovaná od myšlenek velkých evropských myslitelů, na straně druhé ovšem přinášela i originální podněty. Vycházela ze zcela jiných podmínek než filosofie evropská, mísila v sobě kulturu a způsob myšlení mnoha národů a nabízela tak nové koncepce i přístupy ke starým filosofickým problémům.

\section{Vliv Latinské Ameriky na José Ortegu y Gasseta}

José Ortega y Gasset se snažil pomoci národům Latinské Ameriky najít vlastní identitu skrze interpretaci amerických dějin i současnosti. Jeho texty se tak v tomto směru hojně zaměřovaly na oblast sociologie a psychologie národů, primárně toho argentinského. Jeho reflexe hispanoamerické mentality, historie a okolností vycházely z dojmů a poznatků, které autor nabyl během svých opakovaných návštěv na americkém kontinentě. I s ohledem na to je on sám označoval spíše za jakési poznámky poutníka, který zemí pouze projíždí, a ne za všeobecné pravdy. Dle svých slov se nesnažil tolik o exaktnost a podrobnou analýzu jednotlivých národů, ale pouze o to být upřímný a přiblížit čtenářům pocity, které v něm jeho návštěvy zemí vyvolaly.

$\mathrm{Z}$ jeho textů je však patrné, že v něm cesty do Argentiny zanechaly hlubokou stopu. Natolik hlubokou, že ve své stati s názvem Por qué he escrito „El hombre a la defensiva“ uvedl: „Chci říct, že dlužím, ani víc ani míň, celou jednu část mého života - situace, emoce, zkušenosti, myšlenky - této zemi... dlužím jednu podstatnou část mne samotného, mého života, Argentině. " ${ }^{14} \mathrm{Z}$ toho důvodu se Ortega snažil na zá-

13 Medin (1994, s. 155).

14 „Es decir, que yo debo, ni más ni menos, toda una porción de mi vida - situación, emociones, hondas experiencias, pensamientos - a ese país... debo una parte sustancial de mí mismo, de mi vida, a la Argentina." Ortega y Gasset (1981, s. 149). 
kladě svých dojmů stanovit diagnózu a po vzoru rodného Španělska navrhnout východisko z krize. Cítil totiž k zemi jistý závazek: „A pokud Argentina přispěla $\mathrm{k}$ tomu, aby utvářela můj život, musím jí přispět, v jakékoliv míře, která je pro spisovatele možná, abych i já utvářel život Argentiny." ${ }^{15}$

Vnímal Latinskou Ameriku jako specifickou formu bývalé koloniální společnosti a uvědomoval si její jinakost. Za jeden z hlavních rysů zdejší společnosti označil jakousi „pórovitost“, kterou přisuzoval množství národů, jazyků a kultur, které na území žily vedle sebe. Zároveň kladl důraz na to, že všechny země sdílejí určitý historický vývoj a kulturní dědictví. Byl toho názoru, že každý národ chce žít svým vlastním osobitým způsobem a cítí jistou antipatii vůči způsobu života národů ostatních. Jak uvádí v knize Evropa a idea národa (Europa y la idea de la nación):

„Být Angličanem, Francouzem nebo Španělem znamená být celistvě člověkem po anglickém, francouzském nebo španělském způsobu. Tento způsob se dotýká všech rozměrů lidství - náboženství, poezie, umění, ekonomie, politiky, lásky, bolesti, slasti - proniká je, prosakuje jimi a uzpůsobuje je. ${ }^{\text {“16 }}$

Ve svých textech se snažil o odhalení charakteristických rysů hispanoamerických obyvatel, a to včetně těch negativních. Patřil mezi ně mimo jiné narcismus, nedostatek solidarity nebo agresivita. $\mathrm{Z}$ tohoto důvodu byly ne všechny Ortegovy texty a v nich obsažené názory přijímány latinskoamerickými autory s pochopením. Za své rozbory argentinské společnosti v textech Pampa... Promesas nebo El hombre a la defensiva sklidil celou řadu negativních ohlasů a mnoho autorů volalo po přepsání jistých, dle jejich názoru hanlivých, pasáží. Mezi ně patřili např́klad Roberto Fernando Giusti (1887-1978) (časopis Nosotros), Manuel Gálvez (1882-1962) (příloha deníku La Nación), Juan Alvárez (La Prensa) nebo Tina Spangerberg (La Razón). Všichni upozorňovali na to, že Ortega soudil zemi z pohledu Evropana, aniž by byl schopen po-

15 Tamtéž, s. 150.

16 Tamtéž, s. 57. 
rozumět vlastnímu hispanoamerickému způsobu myšlení. ${ }^{17}$ Existovala však i skupina, která s Ortegovým názorem souhlasila a označovala jej za popis tragického osudu národa. Filosof José Luis Ímaz (1928-2008) se například v rámci své tvorby snažil Ortegovy reflexe začlenit do kontextu země v daném časovém období a doplnit je tak o chybějící element hispanoamerické okolnosti, který Ortega nebyl schopen jako „pouhý návštěvník“ zachytit. ${ }^{18}$

Nutno podotknout, že Ortegova kritika nebyla pouhou kritikou bez nabídky řešení. Stejně jako v případě Španělska následně navrhoval postup, který by měl zemi pomoci nalézt východisko z krize. Jeho „útok“ tedy nebyl tolik útokem, jako spíše snahou o nalezení dokonalosti ve způsobu, jakým člověk žije svůj život. Nejdříve nastínil, co vše je nedostatečné, aby následně usiloval o nalezení autenticity národa a vytvoření morálního projektu, který má směřovat k ideálu. Dosažení této autenticity ale podle něj vyžadovalo opuštění utopických představ o vlastním státě.

V eseji Pampa... Promesas Ortega hovořil velice otevřeně o nedostatcích, které byly dle jeho názoru důvodem pro krizi identity, v níž se Argentina nacházela. A ačkoliv uvedl, že „nevěří tomu, že někde existuje lid tolik oproštěný od předsudků, s větší prozíravostí, než ten, který potkal v Argentině...", ${ }^{19}$ na následujících řádcích zemi vytkl, že podstatou argentinského života je být pouhým př́íslibem a že pampa není ničím jiným, než krutou a prázdnou realitou. Zašel ve své kritice však ještě mnohem dál: „Pravdou je, že aktuální Argentina neměla existovat, chci tím říct, že pouhé síly historické mechaniky nestačí k vysvětlení její existence. “20

Argentina byla dle jeho názoru nahlížena jako symbol „defektní humanity“ “. ${ }^{21}$ Ortega tento fakt připisoval silnému vlivu politiky a ignorantství vưči historii. Společenský život Argentinců v něm vyvolal dojem, že

17 Maharg (1992, s. 16).

18 Aras (2004, s. 30).

19 Ortega y Gasset (1981, s. 30).

20 „La verdad es que Argentina actual no debía existir. Quiero decir que las meras fuerzas de mecánica histórica que le han favorecido no bastan para explicar su existencia." Ortega y Gasset (1981, s. 116).

21 Ortega y Gasset (1981, s. 114). 
je stát oddělený od sociální spontaneity a autenticity. Tvrdil, že myšlenky, gesta i slova zdejších mužů nejsou produkovány vitálně, ale jsou pouhým nástrojem pro vnější použití; hovoří o životě, ale nežijí jej. Pro něj však v souladu s učením o vitálním rozumu neexistuje život bez vitálního zájmu, který by jej utvářel. Jinými slovy neexistuje život pro život, ale žijeme vždy pro něco a někoho. Argentinci však dle jeho názoru nežijí autenticky, ale pouze z iluzí, které oni sami nazírají jako realitu. „Argentinec je člověkem obdivuhodně nadaným, který se ale ničemu neodevzdává. Evropan se odevzdává životu, osudu, a proto je samotný jeho život osudem.“22 Argentinec však svůj osud nepřijímá, má jej vložený do ideálu, který sám o sobě má. Neodevzdává se realitě, ale pouhému obrazu. Nežije tedy sám za sebe, ale pouze ve svém vlastním fiktivním obraze. „V důsledku toho se Argentinec nahlíží jako odraz své vlastní imaginace, je vlastně takovým narcisem, který nosí vše s sebou: realitu, obraz i zrcadlo." 23

Reforma sociálního života Argentiny tedy spočívala v nalezení autenticity života, upuštění od starých a nefunkčních vzorců a nalezení nových, které by byly v souladu s lidskou vitalitou a vedly k naplnění vlastního osudu. Ortega tvrdil, že definovat „amerického člověka“ (el hombre americano) není možné, nebot' jeho vlastní historie ještě ani nezapočala. On sám totiž stále žije v prehistorii. V ní nefigurují konkrétní lidé ani jejich osud, ale především čistá okolnost. Amerika doted' neměla „svého“ člověka, ale pouze člověka, který se nacházel v jistých okolnostech, situacích a stádiích. ${ }^{24}$ Zároveň hovořil o tom, že své místo v rámci své historie nenajdou, pokud nebudou jednotně usilovat o nalezení rovnosti mezi národy. Španělsko i Latinská Amerika pro Ortegu představovaly oblasti na okraji moderního světa, které měly k Evropě velmi problematický vztah, charakteristický odmítnutím europocentrismu. Stejně jako v př́padě Španělska spatřoval cestu revitalizace latinskoamerických národů zejména v německé vědě a v moderní evropské filosofii. To, co kultivovalo podle jeho názoru vyspělé Německo, mělo pomoci kultivovat i jeho rodnou zemi a následně země Latinské Ameriky.

22 Tamtéž, s. 125.

23 Tamtéž, s. 140.

24 V případě Latinské Ameriky ve stádiu koloniálním. Ortega y Gasset (1981, s. 44). 


\section{Vliv José Ortegy y Gasseta na hispanoamerické myšlení}

Vliv José Ortegy y Gasseta na hispanoamerické myšlení byl patrný již od jeho první návštěvy Argentiny v roce 1916 a přetrval ve větší či menší míře až do konce 80 . let minulého století. Jedná se bezpochyby o jednu z nejvýraznějších postav, které ovlivnily myšlení v mnoha zemích a v mnoha oblastech, filosofií počínaje a literaturou konče. Během prvního desetiletí 20. století se však jednalo spíše o jakési souznění s Ortegovým způsobem uvažování, než o vliv konkrétních koncepcí. Zejména skupina mexických učenců zvaná „Athenaeum mladých“, kam se řadili autoři jako Alfonso Reyes (1889-1959), Pedro Henríquez Ureña (1884-1946), Antonio Caso (1883-1946) nebo José Vasconselos (1921-1924), ti vnímali příznivě zejména Ortegův zájem o historičnost filosofie a evropskou historii dějin, především $\mathrm{s}$ ohledem na komplikovaný vztah k evropskému kontinentu, který Hispanoamerika sdílela se Španělskem.

V roce 1914 Ortega vydal své Meditace o Quijotovi (Meditaciones del Quijote), obsahující známou větu: „Já jsem já a moje okolnost, a když ji nezachráním, nezachráním se ani já“ ${ }^{25}$ která zasáhla výrazně nejen jeho rodné Španělsko, ale také americký kontinent. Meditace o Quijotovi obsahují celou řadu skrytých významů. Stejně jako postava Dona Quijota, i samotné Španělsko podle Ortegy trvalo na ideálech, které tato postava zastupovala. Abychom byli schopni porozumět problémům dané země a důvodům krize, musíme nejdřive porozumět jí a všem jejím okolnostem. Ortegova nauka o okolnostech vychází ze zkoumání takzvaných malých realit. Základní myšlenkou této koncepce je, že člověk není schopen poznat celek a jeho komunikace se světem probíhá právě prostřednictvím těchto malých realit. Ortegova teorie okolností potom situuje život každého jedince do určitého místa a času. Každý člověk je tak člověkem ve vztahu s tím, co jej obklopuje. „Okolnost! Circum-stancia! Mlčenlivé věci ležící v našem bezprostř̌edním okolí. “" ${ }^{26}$ Ortegovou okolností bylo tedy Španělsko, Evropa, moderní epocha. Každý z nás žije v okolnostech, které jsou včleněny do širších okolností. Okolnosti Ortega nečlení hie-

25 Ortega y Gasset (2007, s 20).

26 Tamtéž, s 16. 
rarchicky. Všechny společně formují pohled na svět u každého jedince. „Pro svou okolnost musíme nalézt odpovídající místo v obrovské perspektivě světa.“27

Tento názor v hispanoamerických autorech rezonoval od 20. let 20. století a Ortegova teorie okolností se promítla do celé řady názorů na obnovu latinskoamerického života. ${ }^{28} \mathrm{Na}$ americkém kontinentě byla však transformována s ohledem na hispanoamerickou skutečnost. Jejím prostřednictvím autoři obhajovali svou odlišnost. Každá ze zemí Latinské Ameriky má svou vlastní okolnost, své nedostatky i přednosti, obyvatele i názory odlišné od moderní Evropy. To však neznamená, že je tato odlišnost činí horšími nebo méně významnými a že nemají právo na svou intelektuální záchranu. Na tomto základě se autoři snažili co nejvíce porozumět okolnostem jednotlivých oblastí i těm společným pro všechny Hispanoameričany, nebot právě porozumění minulosti a přítomnosti dle jejich názoru vedlo k budování lepší budoucnosti. ${ }^{29}$ Základním předpokladem bylo uvědomění, že velká odlišnost latinskoamerických zemí od těch evropských je zcela v pořádku, a že ani v rámci Ameriky nejsou všechny národy stejné. Každý má své geografické, historické i kulturní charakteristiky a jenom díky nim bude možné vytvořit takovou filosofii, která bude zcela v souladu se způsobem, jakým autoři kontinent nazírají. Z těchto myšlenek ve svých dílech kromě Gaose a Romera vycházeli také autoři jako Juan Carlos Torchia-Estrada (1927-2016), Eugenio Pucciarelli (1907-1995) nebo Adolfo Carpio (1923-1996). ${ }^{30}$

Ještě větší vliv než Meditace o Quijotovi měla kniha Úkol naší doby (El téma de nuestro tiempo), vydaná v roce 1923. Ta mimo jiné kladla důraz na přijetí specifických podmínek a okolností různých zemí a kultur. S ohledem na sociokulturní kontext byl pak hispanoamerickými autory s nadšením přijímán Ortegův perspektivismus. Podle něj je skutečnost poznatelná pouze z hlediska různých perspektiv, z nichž je každá ta správná. Jediná realita, která je člověku dána, je ta jeho konkrétní, v konkrétním životě. Bytí ve světě je perspektiva, která nepředstírá být

\footnotetext{
27 Tamtéž, s 19.

28 Housková (2006, s. 17).

29 Naessens (2009, 138).

30 Tamtéž, 155.
} 
absolutní a člověk není jen pasivním subjektem, ale jeho život je neustálým konáním a sebe-uskutečňováním. ${ }^{31}$ Každý jedinec má podle Ortegy svá hlediska, stejně tak jako každá epocha a každá generace. Teorii generací, která byla v knize nastíněna, potom primárně nastupující mladá generace vnímala jako nástroj pro nalezení svého místa ve společnosti a myšlenka významné funkce nových generací byla hojně vyzdvihována mladými intelektuály. V Mexiku o ní psali např́klad Daniel Cosío Villegas (1989-1976) nebo Manuel Goméz Morin (1897-1972), oba hovořili o tom, že východiskem ze složité mexické situace by měla být právě nová generace a nová vitální senzibilita. Také Víctor Haya de la Torre (1895-1979), který byl v Peru považován za lídra studentů, se kriticky vyjadřoval $\mathrm{k}$ původním generacím autorů a souhlasil se svým kolegou Manuelem Gonzálezem Pradou (1844-1918), který na adresu latinské Ameriky poznamenal: „staří do hrobu a mladí k dílu“32 a mladá generace studující na univerzitách pro něj představovala prostředek $\mathrm{k}$ velkým změnám ve společnosti. ${ }^{33}$

Pluralita perspektiv je u Ortegy spojena rovněž s pluralitou kultur. Autoři Latinské Ameriky, kde vedle sebe na relativně malém území koexistovala celá řada národů, nalézali $\mathrm{v}$ perspektivismu velké zalíbení a sloužil jim jako nástroj pro sebereflexi. ${ }^{34}$ Teorie kultur, kterou Ortega formuloval ve svém eseji Atlantidy (Las Atlántidas) z roku 1924, se zabývala historickým smyslem pro různost kultur v Evropě v první čtvrtině 20. století. Hovořil v ní o rozš̌řrení historického horizontu Evropy, zájmu o jiné civilizace a zániku oněch dávných Atlantid. I evropská kultura je jen jednou z mnoha, ale má svůj historický smysl (sentido historico). ${ }^{35}$ Ten nám podle Ortegy umožňuje snahu o přesáhnutí rozmanitosti. Nestačí pouze vnímat hluboké rozdíly u jednotlivých lidí a epoch, ale je třeba zároveň být schopen nahlédnout jejich omezení s jakýmsi přesahem. Zkoumání generací a také analýza historie jednotlivých národů byly hojně diskutovaným tématem u hispanoamerických autorů..$^{36}$

31 Ortega y Gasset (1997, lekce 10 a 11).

32 „los viejos a la tumba, los jóvenes a la obra.“ De la Torre, s. 24.

33 Medin (1994, s. 49).

34 Housková (2006, s. 18).

35 Tamtéž, s. 20.

36 Santamaría García (1993, s. 284). 
Ortegovy myšlenky a jeho kulturní dopad na americkém kontinentě byly patrné především od 30. let 20. století. Ortega značně ovlivnil i způsob, jakým byla filosofie přijímána. Hispanoameričtí autoři oceňovali především jeho snahu o nápravu intelektuální situace ve Španělsku a o nalezení léku na toto „onemocněni“ země. V Mexiku po jeho vzoru usiloval o to samé Samuel Ramos. Ve své knize Perfil del hombre y la cultura en México (1934) se ptal po identitě země a uváděl, že stejně jako Španělsko, se i Mexiko snaží najít svou úlohu ve světě a vymezit se vůči Evropě. Usiloval o analýzu mexické minulosti a o nalezení výchozího bodu pro budování budoucnosti země. Mexiko podle něj existovalo oddělené od své reality a bylo zapotřebí najít takovou perspektivu, která by Mexičany jako jediná dokázala zachránit. ${ }^{37}$ Vnímal teorii perspektivy jako něco, co by Mexičanům umožnilo přestat se nahlížet očima cizince a přimělo je vidět svět z jejich vlastní perspektivy a budovat vlastní mexickou realitu i kulturu. „Nechceme kulturu bez života, ani život bez kultury, ale živoucí kulturu ... která nám umožní porozumět co nejlépe mexické realitě.“"38 Ideálem kultury byla v jeho podání realizace nového humanismu. ${ }^{39}$

O záchranu ne pouze „,̌panělského“, ale „hispánského“ života se snažil také Ortegův žák José Gaos. Ten začal po svém př́íchodu do Mexika šířit myšlenky svého učitele, které vnímal jako prostředek pro oživení hispanoamerického myšlení. Zabýval se také zkoumáním historie filosofie. Tázal se po tom, zda je možné o ní hovořit nejen $\mathrm{v}$ Mexiku, ale $\mathrm{v}$ celé Latinské Americe. Pro Gaose byla mexická historie součástí historie filosofie jako takové v obecném slova smyslu, mezi oběma však docházelo ke konfliktu. Problém latinskoamerické filosofie totiž pro něj spočívá v její neautenticitě a neoriginalitě. Ačkoliv tedy existuje a je součástí historie filosofie, zároveň neexistuje v tom smyslu, že by byla autentická a originální. Historie filosofie by podle Gaose měla být studována jako součást historie myšlení, která je součástí historie idejí (historia de las ideas). Upozorňoval také na důležitost vztahu mezi historií a filosofí. Metodu, kterou nabízel Ortega v Meditacích, Gaos přejímal a vnímal ji jako nástroj, který umožňuje retrospektivní analýzu historického vývoje idejí v Mexiku a v rámci mexic-

37 „El ideal de nuestra cultura debe ser la realización de un nuevo humanismo.“ Ramos (1938, s. 80).

38 Ramos (1943, s. 140).

39 Ramos (1938, s. 80). 
ké historie. $4^{00}$ Bylo podle něj zapotřebí zkoumat autentické mexické texty, které by prokázaly existenci originálního mexického myšlení. Hodnotu nalézal především v tom, co nazýval „myšlením ve španělském jazyce“. Dějiny filosofie vnímal jako nadřazené filosofii samé, okolnosti a lidskému životu. ${ }^{41}$ Ztotožňoval se také s Ortegovým perspektivismem. Byl přesvědčený o tom, že jsme všichni stejní, se společnými právy a vlastními charakteristikami a se specifickými odlišnostmi. Každá obec má svou vlastní perspektivu a každá z nich je pravdivá.

Směr, který Gaos v návaznosti na Ortegu rozvinul, bývá nazýván Movimiento de la Historia de las Ideas. Měl odezvu i v dalších částech hispanoamerického světa. Kromě Gaose nebo Leopolda Zey, který se zabýval nejen historickým zkoumáním, problémem morálky a kulturou života, ale také tím, jaký vliv na ně má geografie, se k němu hlásil v Argentině Francisco Romero nebo Coriolano Alberini (1886-1960), v Brazílii Cruz Costa (1904-1978), v Porto Ricu Arturo Ardao (1912-2003).42

Na myšlenky Gaose a Romera př́mo navazoval Leopoldo Zea Aguilar. Ten ve své tvorbě reflektoval Ortegovu teorii okolností i perspektivismus a poukazoval na to, že pro Ortegu existovala na americkém kontinentě pouze Argentina a Spojené státy a že Mexiko zcela ignoroval. Dle jeho názoru se tak Ortega sice snažil o reflexi hispanoamerického myšlení, avšak nahlížel jej z perspektivy Evropana. ${ }^{43}$ Jeho filosofie se tak sice stala nástrojem pro analyzování hispanoamerické okolnosti a usilování o autentickou filosofii, avšak aniž by on sám porozuměl realitě těchto „mladých“ a dle jeho názoru nevyspělých národů. ${ }^{44}$ Ortega hovořil o potřebě vybudování nové filosofie, ale zároveň zastával názor, že Amerika svou okolnost zachránit nedokáže. Zea naopak věřil ve vybudování nové filosofie, která kromě Ortegových myšlenek vychází z Ramosova humanismu a Gaosovy snahy o rekonstrukci historie idejí. Porozumění okolnostem jednotlivých lidí může dle Ramose $\mathrm{v}$ širší perspektivě vést až $\mathrm{k}$ porozumění lidstvu a $\mathrm{k}$ vytvoření autentické filosofie. ${ }^{45}$

40 Ramos (1943, s. 145).

41 Santamaría García (1993, s. 298).

42 Quesada (1976, s. 152).

43 Zea (1983, s. 14).

44 Tamtéž, s. 18.

45 Bentivegna (2017, s. 29). 
Otázka po identitě národů se stala klíčovým zájmem většiny myslitelo̊ a vycházela celá řada knih, které se touto problematikou zabývaly. Na tomto místě můžeme zmínit například dílo Augusta Salazara Bondyho Filosofía en el Perú, Gaosovo El pensamiento hispanoamericano (1944), Radiografía de la Pampa, jejímž autorem je Ezequiel Martínez Estrada nebo Laberinto de la Soledad od Octavia Paze. Snaha o nalezení vlastní identity se mísila s hledáním společných rysů v rámci latinskoamerické filosofie.

Ortega však zdejší autory ovlivňoval nejen svými texty a přednáškami, ale také díky časopisu Revista de Occidente, který latinskoamerickým autorům od roku 1923 zprostředkovával aktuální evropské myšlení. V prvním vydání časopisu Ortega v předmluvě uvedl, že si klade za cíl „prezentovat čtenářům esenciální panorama života evropského i amerického“..46 V časopise byly vydávány články autorů, kteří nebyli do španělštiny běžně překládáni jako Spengler, Freud, Simmel, Scheler, Russell a zahrnoval témata z filosofie, sociologie, historie, literatury, vědy nebo umění. Kromě filosofů tak Ortegovy myšlenky ovlivňovaly také celou řadu soudobých hispanoamerických literátů jako Xavier Villaurutia (1903-1950), Jorge Cuesta (1903-1942) nebo Jaime Torres Bodet (1902-1974). ${ }^{47}$

Časopis slavil úspěch zejména $\mathrm{v}$ Argentině, ale později se jeho vliv rozšířil i do Chile. Ortega zároveň participoval při tvorbě latinskoamerického Editorial Calpe, ze kterého se roku 1925 stal Espasa-Calpe a který byl hojně čtený v Mexiku a Argentině. ${ }^{48}$ Inspiroval také publikace dalších intelektuálně zaměřených časopisů jako například Contemporáneos (1925), Ulises (1927-1928), Sur, pro který přispívala Victoria Ocampo (1890-1979), její sestra i manžel Adolfo Bioy Casares (1914-1999), Eduardo Mallea (1903-1982), Jorge Luis Borges (18991986). Po roce 1939 dorazili do Buenos Aires další autoři ovlivnění Ortegou, kteří do časopisu začali přispívat, jako Rosa Chacel (1898-1994), Francisco Ayala ( $\left.{ }^{*} 1934\right)$ a aniž by byli v Argentině, přispívali do něj také María Zambrano a José Ferrater Mora (1912-1991). 49

46 Ortega y Gasset (1923).

47 Medin (1994, s. 35).

48 Pachón Soto (2019, s. 55).

49 Medin (1994, s. 38). 
Patrně i z toho důvodu zájem o Ortegu a jeho myšlenky v Latinské Americe neopadl ani po autorově smrti roku 1955. Až do 8o. let byly jeho texty hojně reflektovány a při př́ležitosti výročí jeho úmrtí vznikala celá řada děl, která se zaměřovala na vliv, který autor na zdejší filosofické myšlení měl. To, jak zásadní postavu Ortega y Gasset pro hispanoamerické autory představoval, shrnul Argentinec Juan Adolfo Vázquez ve svém článku Ortega como circunstancia do jediné věty: „Ortega je naše okolnost. “50

\section{Literatura}

Aras, R. (2014): „Ortega, profeta del destino latinoamericano: la identidad como ,autenticidad“." Cuadernos del Centro de Estudios de Diseño y Comunicación (47): 25-36.

Bentivegna, G. (2017): „Zea, Ortega y Gasset y la circunstancia hispanoamericana." Revista de filosofía 49 (142): 9-34.

Černá, J. (2012): „Qué se debe a España? Spor o význam Španělska v evropských intelektuálních dějinách." Dějiny - teorie - kritika 9 (2): $230-245$.

Forbelský, J. (1999): Španělská literatura 20. století. Karolinum, Praha.

Gomez-Martinez, J. L. (1983): „Presencia de America en la obra de Ortega y Gasset.“ Quinto centenario (6): 125-160.

Gracia, J. \& Vargas, M. (2013): „Latin American Philosophy.“ In The Stanford Encyclopedia of Philosophy [online]. Ed. E. N. Zalta, 2013, aktualiz. 2. 4. 2018 [cit. 9. 2. 2020]. Dostupné z: https:// plato.stanford.edu/archives/sum2018/entries/latin-american-philosophy/.

Gutiérrez Simón, R. (2018): „Ortega frente a un pueblo joven.“ Res publica: revista de historia de las ideas políticas 21 (3): 517-528.

Housková, A. (2006): „Ortega a Amerika.“ In Padesát let od smrti José Ortegy y Gasseta: sborník texti̊, eds. J. Forbelský \& J. Loužek. Centrum pro ekonomiku a politiku, Praha.

50 Vázquez (1956, s. 31). 
Maharg, J. (1992): José Ortega y Gasset. Ediciones de Cultura Hispánica, Madrid.

Medin, T. (1994): Ortega y Gasset en la cultura hispanoamericana. Fondo de Cultura Económica, México.

Naessens, H. (2009): „Una ,visión continentalista“ de la filosofía: José Gaos y Francisco Romero." Latinoamérica [online]. (48): 137-159 [cit. 20. 7. 2020]. Dostupné z: http://www. scielo.org.mx/scielo.php?script=sci_arttext\&pid=S1665$-85742009000100007 \& \operatorname{lng}=$ es\&nrm $=$ iso.

Ortega y Gasset, J. (2007): Meditace o Quijotovi. Host, Brno.

Ortega y Gasset, J. (1993): Evropa a idea národa. Mladá fronta, Praha.

Ortega y Gasset, J. (1981): Meditación del pueblo joven y otros ensayos sobre América. Revista de Occidente en Alianza Editorial, Madrid.

Ortega y Gasset, J. (1977): Qué es filosofía? Alianza Editorial, Madrid.

Ortega y Gasset, J. (1967): España invertebrada: bosquejo de algunos pensamientos históricos. 15. ed. en castellano. Ediciones de la Revista de Occidente, Madrid.

Ortega y Gasset, J. (1923): „[Předmluva.]“ Revista de Occidente (1): [1-3].

Pachón Soto, D. (2019): „Ortega y Gasset, la filosofía de la circunstancia y la ontología de la posibilidad histórica." Cuadernos CANELA 30: 51-64.

Poláková, D. (2017): Mezi propastí a nebem. Fin de siècle v prozaickém díle Rubéna Daría. Karolinum, Praha.

Miró Quesada Rada, F. (1976): Ciencia política, actualidad y perspectiva. Biblioteca Peruana de Ciencia Política, Lima.

Ramos, S. (1943): Historia de la filosofía en México. Imprenta universitaria, México.

Ramos, S. (1938): El perfil del hombre y la cultura en México. 2. ed., P. Robredo, México. 
Santamaría García, A. (1993): „El legado filosófico de José Ortega y

Gasset en América Latina. José Gaos y el Movimiento de Historia de las Ideas." Anuario de Estudios Americanos 50 (2): 279-308.

Serna, E. (2013): „La Filosofía En La Historia De América Latina.“ Cuestiones de Filosofía (15): 171-198.

Vázquez, J. A. (1956): „Ortega como circunstancia.“ Sur (241): 29-32.

Zea, L. (1995): „Ortega y Gasset en la cultura hispanoamericana.“ Estudios interdisciplinarios de América Latina y el Caribe [online]. 6 (1): 141-146 [cit. 10. 1. 2020]. Dostupné z: http:// eial.tau.ac.il/index.php/eial/article/view/1210/1237.

Zea, L. (1983): „Presencia cultural de Ortega en Hispanoamérica.“ Quinto centenario (6): 13-36.

\begin{abstract}
José Ortega y Gasset and Hispano-American philosophical thinking The present paper discusses the intellectual influence of the Latin American countries on philosophical thinking of the prominent Spanish modern philosopher José Ortega y Gasset, as well his personal interest in this area, especially in Argentina. It also focuses on the influence of Ortega on HispanoAmerican philosophical thinking. On the first pages the text presents a brief history of philosophical thinking in Latin America. It then focuses on Ortega's efforts to find an intellectual "cure" for the Hispano-American problem associated with the search for national identity. It also describes Ortega's ideas, theories and concepts that had the most significant influence on the work of the intellectuals in Latin America - namely the theory of circumstances, perspectivism, ratiovitalism, the theory of generations and the theory of cultures.
\end{abstract}

Key words: José Ortega y Gasset, Hispano-American philosophical thinking, Latin America, Ortega and Argentina, Ortega and Hispano-America, national identity, circumstances, perspectivism, ratiovitalism

Vozková, K. (2020): „José Ortega y Gasset a hispanoamerické filosofické myšlení." Filosofie dnes 12 (2): 3-19. Dostupné z www.filosofiednes.ff.uhk.cz 


\title{
Uplatnění pozdní filozofie L. Wittgensteina v myšlení C. Geertze
}

\author{
Kristina Vejnbender \\ Fakulta humanitních studií \\ Pátkova 2137/5, 18200 Praha 8 \\ Univerzita Karlova \\ kristina.veinbender@seznam.cz
}

Cílem článku je nabídnout analýzu toho, jakým způsobem uplatňuje Clifford Geertz pozdní filozofii L. Wittgensteina v metodologii společenských věd. Ve svých pracích Geertz vyjadřuje nesouhlas s brojením proti relativismu v antropologii, i když odmítá zaujmout pozici relativisty nebo anti-relativisty. Své pozici ř́ká anti anti-relativismus. Za hlavní problém obou táborů považuje mylnou představu kultury jako nedynamického a uzavřeného celku, která vyplývá z filozofické představy „ideálních“ pojmů. Taková představa je podle něj zvlášt neudržitelná v dnešním globalizovaném propojeném světě. Naopak, za vhodný metodologický nástroj považuje Wittgensteinovo pojetí „jazykové hry“, které nabízí pohled na jazyk a kulturu jako na sít vzájemně podobných praktik, které nejdou shrnout do základních premis a které netvoří celek s jasnými hranicemi.

Klíčová slova: anti anti-relativismus, antropologie, jazyková hra, Wittgenstein, Geertz

\section{Úvod}

Dějinám antropologie dlouhou dobu dominoval evropocentrický pohled na člověka a takzvané primitivní společnosti byly desítky let považovány za méně vyvinuté než ta západní. Zatímco evropské myšlení se postulovalo jako racionální, vědecké a logické, jiné kultury byly brány za evolučně nedospělé a iracionální. Praktiky nezápadních kultur byly v konečném důsledku prezentovány, jak formuloval Wittgenstein ve svých poznám- 
kách k Frazerovi z roku 1931, jako „hloupé“ nebo „chybné“. ${ }^{1}$ V době, kdy vyšla slavná kniha britského antropologa Richarda Evanse-Pritcharda Witchcraft, Oracles, and Magic among the Azande (1937)², v níž vědec popisuje magické rituály afrického kmene Azande, nebyl názor, že myšlení obyvatelů domorodých kmenů může postrádat racionalitu, logiku nebo zdravý rozum, vlastní pro lidi západní civilizace, vůbec výjimečný.

Ve své knize Evans-Pritchard popisuje místní pověry, podle kterých někteří lidé jsou čarodějové a dokážou ublížit jiným díky svým vrozeným a dědičným schopnostem. ${ }^{3}$ Přestože Evans-Pritchard odmítá evolucionistický pohled svých předchůdců (představený např́íklad J. Frazerem ve „Zlaté Ratolesti“), podle kterých se dají společnosti rozdělit na vyvinutější a méně vyvinuté, pořád na ně nahlíží normativní optikou západního antropologa. Podle jeho názoru by se sice dalo připustit, že vysvětlující roli vědy obsadila ve společnosti Azandů magie, nicméně podle něj chybí jejich uvažování vnitřní logická konzistence. $Z$ našeho pohledu se zdá, píše Evans-Pritchard, že pokud je prokázáno, že člověk je čaroděj, pak celý jeho klan tvoří ipso facto čarodějové, protože klan Zande je skupinou lidí, kteří jsou př́buzní přes mužskou linii. Azandové sice vidí logiku v tomto argumentu, nicméně odmítají přijmout jeho závěry. Pokud by to udělali, pak by celá představa o čarodějnictví byla kontradikční, uzavírá antropolog. ${ }^{4}$ Když Evans-Pritchard porovnává závěry Azandů a „náš pohled“, dochází k tomu, že jejich myšlení obsahuje silnou kontradikci, která znemožňuje racionální myšlení.

Racionalita a zdravý rozum jsou pro Evanse-Pritcharda univerzální (a teoretické) hodnoty, které se bud' manifestují v podobě, v jaké je definuje západní společnost, nebo zcela chybí. Oproti tomu relativistický pohled na kulturu považuje pojmy jako racionalita nebo zdravý rozum za zcela závislé na kontextu, v němž se objevují. Pojmy jako racionalita jsou pro relativisty praktikou, která je ukotvena hluboce v kultuře. Postupy, které aplikují př́slušníci kmene, jsou z pohledu relativistů stejně racionální jako ty západní, a to díky vlastnímu kontextu, v němž se vyskytují. Oba postoje, jak etnocentrismus, tak relativismus, se ve svých extrémních podobách vyznačují metodologickým problémem porozumění

\footnotetext{
1 Wittgenstein (1993b, s. 121).

2 Evans-Pritchard (1976).

3 Tamtéž, s. 1.

4 Tamtéž, s. 3.
} 
jiným kulturním kontextům. Zatímco etnocentrista považuje všechny příslušníky kmene Azande za neracionální, relativista není schopen rozpoznat ty racionální od těch neracionálních.

V tomto článku bych chtěla představit další cestu, která je inspirována pozdní filozofií Ludwiga Wittgensteina a která místo toho, aby zaujala jednu ze zmíněných pozic, zpochybňuje pohled na kulturu jako takový. Touto cestou se vydal antropolog Clifford Geertz a jeho anti anti-relativismus z velké části pramení z jeho interpretace Wittgensteinova pozdního díla.

Cílem článku je analyzovat zpo̊sob, jímž Geertz využil pozdní filozofii L. Wittgensteina, aby nejen odmítl myšlenku univerzality pojmů a významů např́íč kulturami, jak to dělali jiní zastánci Wittgensteina, ale i ukázal, jak taková debata vyhrocena do dvou protipólo̊ postrádá smysl. Stejně jako Wittgenstein se domníval, že kulturní významy se produkují na základě každodenních praktik v rámci sociálního a jazykového kontextu, v nichž se nacházejí. Z Wittgensteina si ovšem odnesl mnohem víc než kulturní podmíněnost pojmů. Inspiroval se Wittgensteinovou koncepcí různorodosti jazykových her a domníval se, že kultura, stejně jako jazyk, je souborem rozmanitých praktik, které se nedají shrnout pomocí několika premis. Stejně jako Wittgenstein zpochybnil představu pojmů jako jasně vymezených množin. Když to aplikoval na pojem kultury, došel k závěru, že není možné zkoumat kulturu či společnost jako uzavřený a statický celek. Konfrontace s cizím a odlišným je podle něj nepostradatelná pro utváření pocitu vlastní identity. Dochází tak podle něj k dialektickému vztahu, kde vlastní identita ovlivňuje porozumění cizímu, které v druhé řadě utvář́i identitu.

V první části článku popíšu kontext tzv. debaty o racionalitě, kde představím dva základní názorové tábory účastníků debaty - relativistů a anti-relativistů, zastoupené P. Winchem a E. Gellnerem. Geertz se díky vlivu Wittgensteinových myšlenek, které také krátce shrnu, odmítl hlásit k některému z těchto z postojů. Zaujal pozici anti anti-relativisty a inspirovaný Wittgensteinem pracoval s představou kultury jako celku složeného z mnoha (jazykových) her. Třetí a závěrečná čtvrtá část se budou věnovat tomu, jak Geertz aplikoval konkrétní rysy jazykové hry na pojem kultury. Skrze rozbor jeho přístupu se na závěr dotkneme i otázky relevantnosti jeho metodologických poznámek vůči současné antropologii. 


\section{Je racionalita kulturně podmíněna?}

Přestože v době vydání výzkumu Azande pořád společnosti dominoval etnocentrimus, s odstupem let se našli tací, kteří závěry Evanse-Pritcharda ostře kritizovali. Tato kritika se do společenskovědních dějin zapsala jako „debata o racionalitě“, časem se přestala zabývat jen konkrétními závěry ohledně myšlení Azande a přerostla do podoby obecné otázky, zda racionalita nebo jakákoliv jiná lidská vlastnost je kulturně podmíněná či nikoliv. $\mathrm{V}$ této části shrneme dva protipóly debaty. Jeden z nich, kulturní relativismus inspirovaný Wittgensteinem představoval P. Winch, jeho hlavním odpůrcem, stejně jako odpůrcem celé filozofie Wittgensteina byl E. Gellner. Na konci kapitoly naznačíme, kterou z cest se rozhodl vydat samotný Geertz.

Etnocentrické závěry Evanse-Pritcharda poprvé veřejně konfrontoval Wittgensteinem ovlivněný filozof Peter Winch, který ve svém článku „Understanding a primitive society“ vznesl námitku, že různé kultury mají různá kritéria pro to, co se dá považovat za racionální. ${ }^{5}$ Podle Winche nám samotný jazyk a společnost, v níž žijeme, ukládá to, co později považujeme za smysluplné nebo racionální a co ne, nikoliv naopak. „Schopnost vidět tento druh smyslu v životě nezáleží pouze na jedinci, kterého se to týká, i když se nedá říct, že na něm to nezáleží vưbec; také to záleží na podmínkách smysluplnosti, které poskytuje nebo neposkytuje společnost, v níž žije, " píše. ${ }^{6}$

Stejnou myšlenku vyjádřil už dřív ve své knize Idea sociální vědy a její vztah $k$ filosofii (1984), ${ }^{7}$ kde poukázal na to, že pokud chceme porozumět zkoumané společnosti, je potřeba se řídit jejími pravidly utváření významů:

„Koncepty a kritéria, podle nichž sociolog usoudí, že ve dvou situacích došlo $k$ témuž, př́padně že byla prováděna táž činnost, je třeba chápat ve vztahu k pravidlům řídícím sociální bádání. Zde však narážíme na vážnou potíž, nebot' v př́ípadě př́rodovědce se musíme vypořádat jen $\mathrm{s}$ jedním souborem pravidel, totiž s tím, jenž rídí vědecké bádání samo, zatímco $\mathrm{v}$ př́padě sociologa je lidskou činností nejen vlastní studium,

5 Winch (1970).

6 Tamtéž, s. 106.

7 Winch (2004). 
nýbrž i to, co studuje. Odtud plyne, že to, co sociolog studuje, musí být vykonáváno podle pravidel, ovšem právě tato pravidla - spíše než ta, jimiž se řídí sociologické bádání - určují, co se ve vztahu k danému typu činnosti pokládá za ,dělání téhož “"8

Myšlenka kulturního relativismu rozhodně nevznikla během takzvaných debat o racionalitě, které částečně rozpoutal Winch. Za sociologického předchůdce kulturních relativistů je často považován Max Weber a jeho teorie funkcionalismu. Ostatně kritik kulturního relativismu, Ernst Gellner, mluví o Winchově (a Wittgensteinově) přístupu výlučně jako o „extrémní podobě funkcionalismu“. 9 Relativistický postoj, který se zformoval během debaty o racionalitě, nejde ovšem zcela ztotožnit s funkcionalismem. Jak podotýká Bryan R. Wilson v úvodu ke sborníku Rationality, přestože ze všech klasických sociologů se Weber se svým funkcionalismem dostal nejblíž k „uznání hranic racionálních postupů výzkumů a porozumění“, nikdy nezpochybnil kritéria racionality samotné. ${ }^{10}$ „Funkcionalismus byl přístupem, který ospravedlňoval výzkum neracionálního chování tím, že odkazoval na ne tolik iracionální „skrytou ruku“, díky níž fungování bylo založeno na vzájemném doplňování se,“ pokračuje Wilson. ${ }^{11}$ Za výdobytek debaty o racionalitě, kterou zahájil P. Winch, můžeme podle Wilsona považovat zpochybnění kritérií racionality jako takových.

Podle Winche, samotná „forma koncepce reality předchází tomu, že rozumíme výrazu ,co věda označuje za pravdivé““. ${ }^{12}$ Nejen vědecká metodologie, ale i řízení se pravidly metodologie vyžadují určitý způsob před-porozumění tomu, co znamená řídit se pravidlem. Právě způsob, jímž přemýšlíme o věcech, určuje, co považujeme za vědecky pravdivé a co nikoliv. Věci, které zpochybňujeme, a tedy zkoumáme, si vybíráme na základě toho, co považujeme za nezpochybnitelnou pravdu a co za úsudek, názor, který jde vyvrátit. Např́lklad, praktiky, které Azande praktikují v souladu s tím, čemu západní civilizace ř́́ká racionalita, ignorujeme jako samozřejmé. Naopak, ty, co jsou v rozporu s naší představou o tom,

8 Tamtéž, s. 88.

9 Gellner (1970, s. 21), Wilson (1970).

10 Wilson (1970, s. vii).

11 Tamtéž.

12 Winch (2004, s. 94). 
co znamená chovat se racionálně, zkoumáme pod drobnohledem. Z pohledu kulturního relativisty máme ke všem praktikám přistupovat jako ke smysluplným, jelikož samotná existence praktiky v rámci kulturní formy je do̊kazem její smysluplnosti.

Hlavní kritik tohoto epistemologického relativismu, E. Gellner, napsal výsměšně: „Ve filozofii a v současném širším intelektuálním klimatu existují výrazné síly, které podporují druh funkcionalismu, kterému dává smysl všechno." ${ }^{13}$ Gellnerova hlavní výtka vůči postoji, který zastává Winch, skutečně spočívá v tom, že „funkcionalismu dává smysl všechno“. Způsobila to podle něj jedna skutečnost, a to že se díky Wittgensteinově pozdní filozofii „jazyk náhle stal svým pánem“. ${ }^{14}$ Už nepotřeboval externí legitimizaci, jelikož normy a praktiky, které se objevují v rámci jazyka, se staly legitimizující samy o sobě. ${ }^{15}$ Sociální praktika měla právo na existenci a považovala se za smysluplnou jenom díky tomu, že byla zaznamenána v řeči. Odpověd’ na otázku, proč používáme jazyk tak či onak, se najednou stala jednoduchá - protože to děláme.

Pokud validita jazyka spočívá v jeho vlastním užití, potom každá praktika, at’ už náboženská nebo kulturní, má právo na existenci, vytýkal Wittgensteinovým následovníkům Gellner. Filozofie by ji podle tohoto pohledu potom měla „ponechat takovou, jaká je“, tedy popsat bez možnosti kritizovat nebo porovnat s jinými praktikami. „Pokud užití je zároveň významem, potom, zcela jistě, náboženská tvrzení mají smysl, copak nejsou užívána, nemají své užití a funkci,“ soudí. ${ }^{16}$ Podobný metodologický přístup zajištuje validitu všem náboženským a ideologickým směrům, aniž by bylo možné některé z nich označit za nesmyslné nebo je vzájemně porovnávat.

Geertzův př́íspěvek k debatě, článek „Distinguished Lecture: Anti Anti-Relativism“17, vyšel teprve v době, kdy se debata už nedala považovat za aktuální. Jeho pozdní zapojení se do diskuze ovšem není chybou právě díky tomu nemusel uspěchaně zaujmout jeden z radikálních názorů a mohl si dovolit kriticky zhodnotit postoje každé strany.

\footnotetext{
13 Gellner (1970, s. 46).

14 Gellner (2005, s. 13).

15 Tamtéž.

16 Tamtéž, s. 291.

17 Geertz (1984).
} 
Kulturní relativismus zastávaný Winchem se skutečně vyznačoval několika teoretickými problémy, které úspěšně zneužívali jeho odpůrci jako Gellner. Odpor vưči relativismu spočíval ve „strachu, že nám kvůli důrazu na rozmanitost, diverzitu, odlišnost, diskontinuitu, vzájemnou nesouměřitelnost, unikátnost ... nezbude nic víc než konstatovat, že se věci jinde mají jinak a kultura činí to, co činí“. ${ }^{18}$

Obava z toho, že relativismus znemožní existenci antropologie, byla ovšem podle Geertze trochu přehnaná. Jak se píše v úvodu ke sborníku Rationality and Relativity, který představoval druhé kolo debat kolem racionality, relativismus „byl v sociální antropologii př́itomen vždy, i když se mu částečně, ale pevně bránilo“. ${ }^{19}$ Podle názoru Geertze dlouhodobé brojení proti relativismu připravovalo antropology o důležitý nástroj zkoumání, který byl spjat se samotnou podstatou antropologického zkoumání:

„At’ už kulturní relativismus původně byl nebo je čímkoliv (a není jediný kritik ze sta, který by ho pochopil správně), dnes slouží z velké části jako strašidlo, které nás má odpudit od určitých zpo̊sobů přemýšlení a přilákat $\mathrm{k}$ jiným. A jelikož ty způsoby myšlení, od nichž jsme odpuzováni, se zdají být přesvědčivější než ty, ke kterým jsme poháněni, a také se zdá, že se ony způsoby nacházejí v srdci antropologického dědictví, chtěl bych s tím něco udělat. Zahánění démonů je praxe, kterou bychom měli provozovat do stejné míry jako samotný výzkum. “20

Nezamlouvaly se mu ani posměšné a povrchní útoky na relativismus. Zatím co etnocentrismus se odmítl zabývat čímkoliv kromě vlastních hodnot, relativismus byl často prezentován jako „nihilismus“.21 Zastánci relativismu byli najednou obviňováni z toho, že „nevěří v existenci fyzikálního světa“ nebo „považují Hitlera jen za chlapíka s neobvyklými zálibami“.22

18 Tamtéž, s. 267.

19 Hollis (1982, s. 1).

20 Geertz (2000a, s. 43).

21 Geertz (1984, s. 264).

22 Tamtéž. 
Geertz se nicméně odmítl hlásit jak k relativismu, tak k anti-relativismu, protože debata, která by měla být analytická, mu často připomínala „výměnu vzájemných varování“. ${ }^{23}$ Anti-relativisté nám nabízejí „znepokojení, vyvolané př́lišným uvažováním o anthropu obecně, že pokud něco není ukotvené všude, pak nemůže být ukotvené nikde“..24 Relativismus nás naopak varuje před „provincialismem - nebezpečím, že naše vnímání se otupí, rozum se omezí, a naše schopnost porozumění se zúží díky prř́liš vědeckému a př́lišs vítanému přijetí vlastní společnosti“..25

Debata mezi dvěma tábory by se dala výstižně shrnout Jacksonovým popisem propasti mezi etnografickým a filozofickým př́stupem: etnografie vyžaduje absolutní ponoření do světa jinakosti a jiných, zatímco filozofie nás chrání před utonutím tím, že nám poskytuje pocit srozumitelnosti, vyrovnanosti a kontroly v matoucím a nepřehledném světě. ${ }^{26}$ Černobílá volba mezi pohledem božího oka filozofa (Gellnera) a etnografickým pohledem domorodce (Winche) Geertzovi nevyhovovala. Představovaly pro něj dvě strany jedné mince - neumožňovaly výzkumníkovi zkoumat a porozumět praktikám, které by byly odlišné od jeho vlastních, aniž by se musel vzdát vlastního pohledu na svět.

Geertz hledal cestu, která by nebyla tolik extrémní a pracovala jak $\mathrm{s}$ výchozí identitou výzkumníka, tak svébytností předmětů zkoumání, a Wittgensteinova filozofie mu takovou cestu poskytla. „Pokud je pravdou to, že jsme připraveni nazvat našimi učiteli ty spisovatele, kteří podle našeho zdání konečně vyslovili to, co jsme sami měli dlouho na jazyku, ale nebyli schopní to vyjádřit ... pak můžu s potěšením nazvat Wittgensteina svým mistrem," napsal. ${ }^{27}$ Nastiňme si, jaké Wittgensteinovy myšlenky tu měl Geertz na mysli.

Zřejmě nejzásadnější vliv na Geertzovo myšlení měla Wittgensteinova představa jazyka jako souboru jazykových her. Je základem toho, k čemu Geertz odkazuje jako k „návratu praktické filozofie“. ${ }^{28}$ Krátce si tuto představu zreprodukujme. Svůj význam získávají podle (pozdního) Wittgensteina slova a věty díky kontextu, v němž se nacházejí, - díky

23 Geertz (200oa, s. 46).

24 Tamtéž.

25 Tamtéž.

26 Jackson (2014, s. 28).

27 Geertz (2000a, s. xi).

28 Tamtéž, s. 139. 
užšímu kontextu v sociální i jazykové praxi v okamžiku mluvení, tedy v jazykové hře, a širšímu kontextu praktik, které se provozují v kultuře nebo společnosti, tedy životné formě. „... promlouvání řeči je částí určité činnosti nebo určité životní formy, " píše. ${ }^{29}$ Wittgensteinova pozdní filozofie decentralizuje pohled na význam jako na pevnou a univerzální danost a poukazuje na různé způsoby užití stejných slov a vět v různých situacích a celcích. Z takového pohledu plyne, že např́iklad představa o racionalitě nebo zdravém rozumu souvisí s kontextem kulturních a jazykových praktik.

Pojmy nenabývají smyslu v teoretickém kontextu věty, jsou součástí činnosti. Jazyk je pro Wittgensteina sociální praktikou, proto představa o tom, co je například zdravý rozum, se odvíjí od toho, co děláme, jak jednáme a co říkáme v běžném životě. Životní forma pak představuje sdílenou praxi a společná přesvědčení, o kterých za běžných okolností nepochybujeme a které aktivně uplatňujeme v řeči, aniž bychom se o tom zamýšleli. „Správné a chybné je to, co lidé říkají, a v řeči se lidé shodují,“ míní Wittgenstein. ${ }^{30}$ Neshodneme-li se v jednotlivých míněních, diskutujeme o tom a snažíme se přesvědčit se navzájem. V řeči, tedy životní formě se ale shodujeme, aniž bychom o tom museli diskutovat. Když mluvíme, řídíme se pravidlem, sdělujeme, dáváme rozkazy, nezpochybňujeme své jednání ze své podstaty. Když ř́íkáme, že něco takto děláme odjakživa, znamená to, že se řídíme návyky nebo zvyklostmi. ${ }^{31}$ Jinými slovy, pohled na svět je sociálně reprodukovatelná činnost, která se předává z generace na generaci a která nejde hodnotit z hlediska kritérií smysluplnosti nebo nesmyslnosti.

„Ř́lká se, že ,každý pohled má své kouzlo‘, ale není to pravda. Správné je říct, že každý pohled má svůj význam pro toho, kdo v něm ten význam vidí (což ale neznamená, že ho vidí jinak, než jaký je). Vskutku, v tomto smyslu je každý pohled stejně významný, " vysvětluje své stanovisko filozof. ${ }^{32}$ Praxe je tedy smysluplná vždy, jelikož aktér vykonávající praktiku vkládá smysl do svého jednání, případně smysl je neoddělitelnou součástí jednání. Z toho plyne, že pro porozumění praxi nestačí podat pouhý souhrn aktivity, ale i kontext, z nějž vzniká smysluplnost aktivity. Klíč

29 Wittgenstein (1993a, § 23).

30 Tamtéž, § 242.

31 Tamtéž, § 199.

32 Wittgenstein (1993b, s. 135). 
k pochopení tohoto kontextu se nachází v detailech každodennosti, a to nejen podle Wittgensteina, ale i Geertze.

Ve své poslední knize Available Light se antropolog explicitně hlásí k filozofům „běžného“, kteří „věří, že odpovědi na nejobecnější otázky jako ,Proč? Jak? Co? Kam?‘ se dají najít v drobných detailech žitého života do té míry, do které odpovědi na ně vůbec existuji“".33 Právě detaily každodennosti podle něj dokážou poskytnout odpovědi na otázku, ,jak skupiny lidí, lidé jako jednotlivci a lidé jako celek, míchají své rozmanité a pestrobarevné hlasy dohromady“. ${ }^{34}$ Jak si později ukážeme, tímto Geertz odmítá pátrat po iluzorní „hloubce“, tedy obecných závěrech, a postuluje, že v práci antropologa - použijme slova Wittgensteinova „jakékoliv vysvětlování musí odpadnout, a na jeho místo musí nastoupit jedině popis“. ${ }^{35}$ Pohledu na kulturu jako praxi a nutnosti se zabývat jejím popisem se budeme věnovat $\mathrm{v}$ dalčí části textu.

\section{Návrat na drsnou půdu: kultura jako praxe}

Geertzův pohled na kulturu jako na praktickou činnost jde nejlépe předvést na př́kladu jeho úvahy o zdravém rozumu.

V knize Local Knowledge se antropolog ostře vymezil vůči analytické tradici, která podle něj považuje „zdravý rozum“ za univerzální způsob lidského uvažování, k němuž často apeluje jako k univerzální samozřejmosti. Místo toho definoval zdravý rozum jako kulturní formu, pro kterou je sice vlastní „přirozenost“, „praktičnost“, „,nemetodičnost“ a „bezprostřednost“", to všechno ale podle něj souvisí s širším kontextem kulturního pozadí. ${ }^{36}$

Zdravý rozum je tedy podle něj kulturně podmíněný. Na jednu stranu, stejně jako oxfordští filozofové jazyka přistupuje ke zdravému rozumu jako k něčemu bezprostřednímu, obsaženému v samotné „situaci, vnitřních aspektech reality, ve způsobu, jak se věci mají“. ${ }^{37}$ Na rozdíl od nich ale považuje zdravý rozum za mnohem „problematičtější a zásadnější záležitost, než se to zdá z pohledu Pař́̌žské kavárny nebo Ox-

33 Geertz (2000a, s. xi).

34 Tamtéž, s. xii.

35 Wittgenstein (1993a, §109).

36 Geertz (1993, s. 85).

37 Tamtéž. 
fordské sborovny“ ${ }^{8}{ }^{8}$ Odmítá akceptovat naturalistické vidění, v němž je zdravý rozum postaven na objektivně daných přírodních faktech, a má tedy univerzální charakter. Naopak, pohled na to, jak se věci mají, podle něj souvisí do velké míry s kulturním pozadím jedince. Pro „primitivní“ národy není svět plný duchů zviřrat o nic méně přirozený, běžný nebo bezprostř̌ední než ten náš, argumentuje. Logika magie je tedy projevem zdravého rozumu do stejné míry, do jaké je uvažování obyvatel Západu. Tento závěr by se u kulturního relativisty dal snadno očekávat. Ale Geertz jde dál a poukazuje na další důležitou vlastnost zdravého rozumu, konkrétně na to, že má podobu jednání.

Když začíná pršet, schováme se pod střechou, protože jinak zmokneme. Ani nestrkáme ruce do ohně, protože se můžeme popálit. „Nikdo při smyslech nepochybuje o tom, že déšt je mokrý; ale najdou se takoví, kteří zpochybní propozici ohledně potřeby se schovat dovnitř, když prší, např́iklad, že je to dobré pro posílení vưle..." 39 Nepochybujeme tedy o tom, co je rozumné nebo přirozené udělat $\mathrm{v}$ té či oné situaci, ale o tom, co by nám mohl přinést opak. Naopak, když o někom řekneme, že jeho chování postrádá zdravý rozum, nemíníme tím, že je „mentálně zaostalý a že nedokáže pochopit, že během deště je mokro a oheň pálí, ale že nedokáže čelit každodenním problémům, které se v životě vyskytují...,“ píše Geertz. ${ }^{40}$

Z Geertzova pohledu nejsou představitelé kmenu Azande o nic hloupější nebo schopnější v řešení běžných problémů než obyvatelé Západu. Jednoduchým vysvětlením jejich odlišného uvažování je jiný způsob jednání, na který jsou zvyklí. Zdravý rozum je pro Geertze především naučené, sociálně reprodukované, kulturně podmíněné každodenní jednání a také postoje, obojí založené na interakci se světem. V tomto zrcadlí Geertz Wittgensteinovu představu životní formy, kterou shrnuje takto: Jednám tak. ${ }^{41}$

Další položkou k zamyšlení je fakt, že některé praktiky mohou být zcela $\mathrm{v}$ rozporu s teoretickými názory, které zastáváme. Když Evans-Pritchard poukazuje na nelogičnost myšlenkových postupů Azandů během procesů identifikace čarodějů, dochází k závěru, že Azandové

\footnotetext{
38 Tamtéž, s. 77.

39 Tamtéž, s. 75.

40 Tamtéž, s. 76.

41 Wittgenstein (2010, § 148).
} 
postrádají logické uvažování. Azandové přesto uznávají jeho teoretické argumenty jako platné, ty pro ně ale nesouvisí s praktickou, každodenní stránkou věcí, tedy s tím, co považují za zdravý rozum. Stejný „paradox“ popisuje Cora Diamond v článku „Rules: looking in the right place“:42

„Pokud těmto lidem sdělíte, že ,medvědi na dalekém severu, kde sněží, jsou bílí, a Nová země se nachází na dalekém severu, kde je sníh‘ a pak se jich zeptáte ,Jakou barvu mají tamější medvědi?‘, odpoví, že vám to nejsou schopní říct, jelikož tam nikdy nebyli. Přitom jsou to lidé, kteří jsou bezpochyby schopni odvodit závěry o věcech, které mají v okolí a s nimiž přicházejí do styku. Nicméně jejich odpovědi výzkumníkům se dají označit za ,gramatické připomínky': ,Vždycky mluvíme o tom, co jsme viděli, a nikdy o tom, co jsme nikdy neviděli"“..43

Stejně jako v případě Azandů lidé z výše popsaného kmene disponují schopností logického odvozování, nicméně jejich běžné praktiky nejsou vždy založeny na tomto principu. Zdá se, že každodenní praxe nemusí mít normativně-racionální základ, nicméně znalost a zběhlost v těchto praktikách je pokládána za základ zdravého rozumu. „Když říkáme, že někdo má zdravý rozum, také předpokládáme, že ... je schopen si s problémy poradit běžným zpo̊sobem a zároveň účinně. " ${ }^{44} Z$ dravý rozum jako kulturní forma není podle Geertze ukotven v teorii, ale v praxi. Je souhrnem rozlišných praktik, které si mohou vzájemně protiřečit. V tomto smyslu hra na „racionální“ myšlení je jen jednou z praktik, které v rámci kultury provozujeme. Stejně jako Diamond se Geertz domnívá, že praxe nemůže být posuzována teoretickým zobecňujícím měřítkem či pravidlem. Při pokusu o zobecnění bychom tímto přišli o spoustu případů, které se vymykají jak naší zkušenosti, tak obecné formulaci. Tento závěr má především významný dopad na představu o antropologii jako vědě.

Etnografovi podle Geertze totiž nezbývá nic jiného než sbírat „letmé př́iklady utvářeného chování“. ${ }^{45} \mathrm{O}$ to se pokouší už ve svém raném díle

\footnotetext{
42 Diamond (1989).

43 Tamtéž, s. 24-25.

44 Geertz (1993, s. 76).

45 Geertz (200ob, s. 20).
} 
Interpretace kultur z roku 1973, kde pro metodologii sběru dat využívá termín „thick description“ (zhuštěný popis), který přebírá od G. Ryle a navazuje na Wittgensteinovu myšlenku významu jako užití. ${ }^{46} \mathrm{Jde}$ o takový popis, který čtenáři nebo divákovi poskytne nejen deskripci lidského chování, ale přiblíží i praxi, v rámci které dává smysl. Místo toho, aby analýza kultury vypadala jako „hrdinský ,holistický útok na ,základní konfigurace kultury“, překlenující ,řád řádů‘, ze kterého mohou být skromnější konfigurace nahlíženy jako pouhé dedukce," věnuje se popisu běžné řeči a každodenních praktik. ${ }^{47}$

Jeden z příkladů uplatnění tohoto pohledu najdeme už v jeho raném díle, v Interpretaci kultur. Když se dá do zkoumání kultury Balijců, zjistí, že hledání „Balijské povahy“ byl věnován nespočet studií, kde byly prozkoumány „mytologie, rituály, společenská organizace, vzorce výchovy dětí, formy práva, dokonce i styly transu“. ${ }^{48}$ Překvapující je pro něho ovšem to, že jen málo literatury se věnuje praxi kohoutích zápasů, i když „každý, kdo byl nějakou dobu na Bali, neomylně poznal hlubokou psychologickou identifikaci balijských mužů s jejich kohouty. ${ }^{49}$ Ukazuje, že běžné praktiky Balijců často odkazují ke kohoutí symbolice, například že běžná řeč je plná odkazo̊ ke kohoutům ve vztahu k mužům. ${ }^{50}$ Skrze podrobný detailní popis zápasů se tak Geertz dostává mnohem „hlouběji“ do kultury než ti, co pátrají po obecné hloubce od samého začátku.

Máme-li shrnout myslitelův programový postoj, pak můžeme říci: Geertz je přesvědčen, že jedině skrze popis praxe se dostaneme k porozumění různým aspektům kultury. Navíc, nejde o praxi jednoho typu, ale velice rozmanitý přehled praktik. Rozmanitosti kultury se budeme věnovat v další části.

\section{Z vlaku na nádraží}

V minulé části jsme naznačili, že se Geertz neomezuje pouze myšlenkou kulturně podmíněného významu. Jeho postoj je značně ovlivněn Wittgensteinovým pojetím jazykové hry, která má povahu činnosti, a proto

46 Tamtéž, s. 6.

47 Tamtéž, s. 451.

48 Tamtéž, s. 460.

49 Tamtéž.

50 Tamtéž, s. 465. 
není redukovatelná na premisy a shrnující závěry. Jelikož jednání není ukotveno v žádném základu než v sobě samém, je těžké shrnout tento základ pomocí obecných vět. A jednotlivé praktiky mohou dokonce být v rozporu s teoretickými domněnkami, pravidly či logikou uvažování. Je tedy problematické posoudit kulturní činnost jako logicky konzistentní nebo nekonzistentní, tedy racionální či neracionální, protože nejde o souhrn vět, ale soubor různorodých praktik.

Druhým rysem jazyka, a podle Geertze i kultury, je jeho vysoká vnitřní heterogennost. Dopadu tohoto pohledu na představu kultury se budeme věnovat v této závěrečné části. Podobně jako je jazyk tvořen nespočtem rozličných (jazykových) her, kterými se prolíná sít rodinných podobností, stejně tak je kultura tvořena nespočtem rozličných praktik, které se navzájem prolínají a kř́íží. A to „podobnosti ve velkém i v malém,“ upřesňuje Wittgenstein. ${ }^{51}$ Zároveň naše touha po tom, abychom ponechali jenom ty „velké“ podobnosti a pevné hranice, může být zaslepující, a to jak v pohledu na jazyk, tak na kulturu.

Právě taková zaslepenost, která pramení z nepochopení vnitřní rozmanitosti pojmů, dominuje podle Geertze tradiční představě o kultuře. Ostatně, jako hlavní a přetrvávající problém sociálních a humanitních věd vidí antropolog „tendenci vnímat diverzitu jako povrch, ale univerzalitu jako hloubku“. ${ }^{2}$ Geertzova kritika navazuje na tu Wittgensteinovu, kterou vyjadřuje ve Filozofických zkoumáních: „Problémy, které vznikají špatným chápáním našich řečových forem, mají charakter něčeho hlubokého,“ konstatuje.53 Jelikož jsme zaslepeni ideálem logické „hloubky“ jako dobré odpovědi, všude hledáme univerzalitu, obecnost a pravidelnost. Jenže abychom pochopili kulturu, nestačí (ani to není možné) jednoduše katalogizovat obsah kulturní formy, domnívá se. Její obsah je podle antropologa tak „vysoce heterogenní, a to nejen napříč společnostmi, ale i uvnitř jednotlivých společností, že žádná logická struktura v nich nejde identifikovat, protože tam jednoduše není“. ${ }^{54}$ Existuje jenom nekonečný „povrch“ rozmanitých ukázek praxe.

Originálním přínosem Wittgensteinova myšlení je podle Geertze jeho schopnost přijmout „nejasnost hranic“ pojmů, z níž plyne, že mů-

51 Wittgenstein (1993a, § 66).

52 Geertz (1984, s. 272).

53 Wittgenstein (1993a, § 111).

54 Geertz (1993, s. 92). 
žeme přestat „neustále hledat rozdíly a obecnosti, které nám mají poskytnout vhled do jakési záhady“. ${ }^{55}$ Životní forma předpokládá takovou míru pozornosti vưči rozmanitým př́lkladům v rámci celku, která znemožňuje megalomanii etnocentrismu a provinční pohled relativismu. Ani relativismus, ani anti-relativismus nejsou z tohoto pohledu zcela udržitelné, protože pojmy a kategorie ztrácí své jasné hranice a je tedy obtížnější je porovnávat.

Z představy „hloubky“ nicméně vychází obě strany účastníků debaty o racionalitě. Jak relativisté, tak anti-relativisté vychází z představy kultury jako jasně vyznačených množin obsahujících určitý počet stejných členů, které všechny sdílí několik velkých podobností. Nejlépe tuto představu přibližuje podle Geertze Levi-Straussova metafora vlaků:

„Vlaky, které jedou vedle sebe, ve stejném směru a s podobnou rychlostí jako ten náš, jsou přinejmenším pro nás přiměřeně viditelné z našeho kupé. Ale vlaky z postranních nebo paralelních tratí, které jedou opačným směrem, vidět nejsou." 56

Metafora vlaků totiž nahlíží na kultury jako na sebe nezávislé, spolu nesouvisející, statické a jasně ohraničené celky. Stejně jako se míjí pasažéři různých vlaků, stejně tak nenajdou společnou řeč ani příslušníci různých kultur. Zatímco jedna kultura může být založena na racionalitě, druhá ji může zcela postrádat, a tím pádem postrádají jakýkoliv společný základ.

Ke kritice této myšlenky využívá Geertz Wittgensteinovu metaforu starého města. Jazyk je podle Wittgensteina tvořen klikatými starodávnými uličkami, ale i moderními rovnými ulicemi, oboje jsou jeho právoplatnými součástmi. ${ }^{57}$ Kultura je pro Geertze něco podobného. Vnitřní rozmanitost města, stejně jako jazyka a kultury, nejde shrnout pomocí zobecnění, pomocí rovných moderních ulic. Pokud bychom takové zobecnění přece jenom učinili, přišli bychom o pochopení toho, co je město. To je to, co se může stát, když se o kultuře uvažuje jako o vlaku.

Wittgensteinova metafora města nahrává Geertzovi i v případě další výčitky vưči představě kultury jako jasně ohraničeného homogenního

55 Geertz (2000a, s. xiii).

56 Tamtéž, s. 76.

57 Wittgenstein (1993a, § 18). 
celku. („Při kolika domech nebo ulicích začíná město být městem?““88) Antropologové se podle Geertze př́liš soustředí na staré město, aniž by věnovali dostatečnou pozornost novým čtvrtím na okraji, které se postupně rozrůstají, prolínají se se zbytkem města, vzájemně se ovlivňují. ${ }^{59}$ Nejenže představa kultur jako na sobě zcela nezávislých celků je podle antropologa teoreticky nemožná, $\mathrm{v}$ dnešním globalizovaném světě tato představa není udržitelná ani z praktického hlediska. Představitelé různých kultur žijí bok po boku vedle sebe, komunikují, ovlivňují se navzájem a vzájemně se utvářejí. Časy „lovců hlav, matrilinearistů nebo lidí, kteří předvídají počasí z vnitřností prasat“ skončily, ironicky podotýká Geertz. ${ }^{60}$ Pokud navážeme na metaforu vlaků, dnešní svět je víc podobný mezinárodnímu nádraží, kde se pasažéři z různých vlaků promíchávají v davu.

Přestože jak relativismus, tak anti-relativismus pracují s chybnou představou kultury, druhý zmíněný směr se podle Geertze vyznačuje i dalším prohřeškem. Brání nám zjistit, v jakém ohledu se vztahujeme ke světu, tím nám znemožňuje plnohodnotné budování vlastní identity. ${ }^{61}$ Různorodost jednotlivců, skupin lidí nebo kultur má napomáhat prohloubení jak vlastní subjektivity a jedinečnosti, tak příslušnosti ke společné kultuře. To je ovšem možné pouze za předpokladu neustálé konfrontace s jinakostí, a tedy uvědomění si vlastní odlišnosti. To nám současný svět, i navzdory přání etnocentristů, umožňuje.

Jako př́klad vnitřní nehomogennosti kultury a potřeby s ní pracovat uvádí Geertz „př́pad opilého indiána a stroje na dialýzu“ ${ }^{62}$ Krátce si ho popišme. Nedostatek strojů na dialýzu si vynutil vytvoření čekací listiny pacientů, jejichž pořadí, aby nedošlo k diskriminaci na základě movitosti, bylo vytvořeno na základě pořadí žádostí. Aby léčba byla účinná, bylo potřeba dodržovat celou řadu opatření včetně striktní diety. Když se dostala řada na indiána, ten odmítl omezit pití alkoholu. Doktoři, kteří mu dialýzu prováděli, se pohoršovali nad tím, že zabírá místo někomu, kdo si léčbu skutečně zaslouží, nicméně se neopovážili indiána od stroje odpojit. Takto př́běh pokračoval několik let, dokud indián nezemřel.

58 Tamtéž.

59 Geertz (1993, s. 73).

60 Geertz (2000a, s. 68).

61 Tamtéž, s. 75 .

62 Tamtéž, s. 81. 
Pomocí popsaného případu chce Geertz poukázat na vzájemné nepochopení dvou příslušníků stejné společnosti - indián jako tvrdošíjný fatalista nepovažoval vlastní změnu za do̊stojný krok, zatímco doktoři, kteří nevěřili na osud, ale na vlastní činy, jeho chování považovali za ostudné. Uvedený př́iklad popisuje střet myšlení a jednání několika představitelů stejné společnosti, který ovšem nejde povýšit na úroveň pravidla či vzorce. Šlo by dokonce tvrdit, že identita obou aktérů příběhu se dotváří právě díky vzájemnému střetu. Společnost tedy není jenom souborem rozmanitých, přitom však statických praktik nebo identit, ale i vysoce dynamickou entitou.

„Hranice jazyka jsou hranice mého světa,“ napsal Wittgenstein v Logicko-filozofickém traktátu. ${ }^{63}$ Podle Geertzova výkladu hranice jazyka nejsou hranicemi světa či životní formy proto, že jsme mentálně a jazykově uvězněni v naší společnosti a plně definováni jejími postoji, nýbrž proto, že skrz jazyk a myšlení definujeme vlastní „intelektuální, emoční a morální prostor, ve kterém žijeme“. ${ }^{64} \mathrm{~S}$ podobnou interpretací Wittgensteinovy pasáže přichází americká antropoložka Veena Das. Podle Das se identita subjektu utváří právě díky jeho hranicím. ${ }^{65}$ Pokud subjekt je hranicí svého světa, pak neexistuje „žádný určitý bod v časovém horizontu jeho života, který by se dal ztotožnit se zdrojem nebo podstatou jeho subjektivity“, tedy nemáme žádnou „esenciální“ podstatu, spíš naopak. ${ }^{66}$ Nejsme nikdy „ukončeným dílem“, protože jsme neustále konfrontováni s něčím novým. A zatímco práce etnografư byla dřív analytického rázu - pochopit vzdálenou kulturu a následně ji shrnout čtenáři -, dnes, když už jiné kultury nejsou vzdálené, ale jsou součástí naší (nebo globální) společnosti, hlavním předmětem zájmu badatelů by podle Geertze měly být zdánlivé „propasti mezi mnou a těmi, kdo myslí jinak než já“. ${ }^{67}$

Práce staré gardy antropologů byla podle Geertze v jakémsi smyslu jednodušší, protože působila za „starých dobrých časů pálení čarodějnic a kanibalismu“, dnešní svět nabízí méně zjevnou a sofistikovanější kulturní diverzitu, upozorňuje. ${ }^{68}$ Úkolem dnešních antropologů je podle

63 Wittgenstein (2007, § 5.6).

64 Geertz (2000a, s. 77).

65 Das (2007, s. 4).

66 Tamtéž.

67 Geertz (2000a, s. 83).

68 Tamtéž, s. 68. 
něj naučit se „rozlišovat jemnější rozdíly“, díky tomu by antropologické práce „mohly začít být sofistikovanější, když už budou méně okázalé“. ${ }^{99}$

Údělem novodobého antropologa není tedy zkoumání odlišností a podobností mezi jednotlivými společnostmi a kulturami, ale zkoumání sítě kulturních praktik a dynamiky jejich vzájemného ovlivňování a vývoje. Sociální, etnické, náboženské skupiny už nejsou vlaky, co se navzájem míjejí. Naopak, mají své průsečíky, společné prostory, přesahy, jedna skupina se prolíná s jinou. Zatímco dříve za jeden z argumentů pro vnímání kultur jako na sobě nezávislých entit sloužila geografická vzdálenost, dnešní globalizovaný svět tuto záminku pro tradiční představu kultury odstranil. Každodennost naší společnosti je tvořena rozmanitostí „západních lékařů a indiánských pacientů“, a právě na to by se novodobí etnografové měli podle Geertze soustředit. K pochopení dnešní společnosti nepomůže ani obecně formulovaný relativismus, ani etnocentrismus, ale pracné popisování rodinné podobností společenských praktik.

Wittgensteinovu životní formu Geertz chápe jako výzvu opustit tradiční společenskovědní výzkum založený na obecných rozdílech mezi „nimi“ a „,námi“. „Sociální svět se přirozeně nedělí na jasné „my“, do kterých se dokážeme vcítit, bez ohledu na to, jak moc se od nich lišíme, a záhadné „oni“, do kterých se vcítit nechceme, ačkoliv neúnavně bráníme jejich právo se od nás odlišovat,“ vzkazuje..$^{70}$ Tímto nám chce Geertz ř́ct, že hranice mezi jakýmikoliv „námi“ a „nimi“ je nejasná a pohyblivá. Jde o sociální konstrukt, který přizpůsobujeme vlastním potřebám, a na to by antropolog neměl zapomínat. Pojem „národ“ tak může zahrnovat zcela odlišné př́pady a praktiky než ten náš a naopak. Abychom pochopili vnitřní dynamiku kultury, neměli bychom se soustředit na celky, ale na různorodé praktiky, které se v něčem potkávají a v něčem se naopak rozcházejí.

\section{Závěr}

Pokud si z díla Geertze odneseme jen myšlenku chybnosti etnocentrismu a významu kulturního kontextu, nepřijde nám, dnešním antropologům a filozofưm, tato myšlenka nějak obzvlášt' objevná. Je ovšem nutné zdů-

69 Tamtéž.

70 Tamtéž, s. 76. 
raznit, že se Geertz prostřednictvím „zhuštěného popisu“ vymezuje vůči antropologii své doby, kdy popis každodenních praktik a uplatnění byl naprosto výjimečný. „Zatímco dnes je mnohem běžnější, že antropologové jsou obeznámeni s pracemi svých kolegů z humanitních oborů, je důležité si uvědomit, že v šedesátých a sedmdesátých letech patřil Geertz k hrstce vzdělanců obhajujících důležitost takového širšího intelektuálního přístupu,“ píše Hana Červinková ve své úvaze „Třicet let poté: Úvaha o interpretativním programu Clifforda Geertze““.71

Jak jsme si ovšem ukázali v této práci, Geertz se neomezil pouze na myšlenku kulturní podmíněnosti. Z Wittgensteinovy filozofie si odnesl mnohem víc - představu o kultuře jako činnosti a pojetí rodinné podobnosti uplatněné na výzkum kulturních praktik. Ve své práci se vzdal pokusu o nalezení objektivních vlastností kultury nebo její vnitřní logické struktury. Jak napsal už v Interpretaci kultur, „logika‘ je zrádné slovo, a o vzhledem $\mathrm{k}$ tomu, že odkazuje jak $\mathrm{k}$ formálním principům myšlení, tak k rozumovým spojením mezi fakty a událostmi““.72 Místo hledání formálních principů se soustředil na popis rozmanité každodenní praxe včetně té jazykové. $Z$ tohoto hlediska jde o odvážný krok dodnes, a to i přestože upřednostnění výzkumů praktik před standardním společenskovědním výzkumem může mít větší výpovědní hodnotu jak v předvídání kulturních změn, tak výzkumu postojů jednotlivých skupin.

Důležitým aspektem nové metodologie je také představa celku jako vzájemně příbuzných, ale nehomogenních členů. Potřeba vzít v úvahu jak „lékaře“, tak „indiánského pacienta“ se dnes ukazuje jako významná potřeba sociální politiky. Toto metodologické hledisko proto považuji za nepostradatelné jak v etnografickém výzkumu jednotlivých sociálních skupin, tak ve výzkumu uplatnění principů demokracie v kontextu dnešní společnosti.

\section{Literatura}

Červinková, H. (2000): „Třicet let poté: Úvaha o interpretativním programu Clifforda Geertze." In Interpretace Kultur: Vybrané Eseje, C. Geertz, Sociologické nakladatelství, Praha 2000, s. $503-527$.

71 Červinková (2000, s. 503).

72 Geertz (200ob, s. 446). 
Das, V. (2007): Life and Words: Violence and the Descent into the Ordinary. University of California Press, Berkeley.

Diamond, C. (1989): „Rules: Looking in the Right Place.“ In Wittgenstein: Attention to Particulars, eds. D. Z. Phillips \& P. Winch, Palgrave Macmillan, London, 1984, s. 12-34.

Evans-Pritchard, E. E. (1976): Witchcraft, Oracles, and Magic among the Azande. Clarendon Press, Oxford.

Geertz, C. (1984): „Distinguished Lecture: Anti Anti-Relativism.“ American Anthropologist 86 (2): 263-278.

Geertz, C. (1993): Local knowledge. Further essays in interpretive anthropology. Fontana Press, London.

Geertz, C. (2000a): Available light: Anthropological Reflections on Philosophical Topics. Princeton University Press, Princeton.

Geertz, C. (200ob): Interpretace Kultur: Vybrané Eseje. Sociologické nakladatelství, Praha.

Gellner, E. (1970): „Concepts and Society.“ In Rationality, ed. B. Wilson, Basil Blackwell, Oxford, 1970, s. 18-50.

Gellner, E. (2005): Words and Things. Routledge, London.

Hollis, M. \& Lukes, S. (1982): Rationality and Relativism. The MIT Press, Cambridge.

Jackson, M. (2014): „Ajàlá’s Heads: Reflections on Anthropology and Philosophy in a West African Setting." In The Ground Between: Anthropologists Engage Philosophy, eds. V. Das, M. Jackson, A. Kleinman \& B. Singh, Duke University Press, 2014, s. 27-50.

Wilson, B., ed. (1970): Rationality. Basil Blackwell, Oxford.

Winch, P. (1970): „Understanding a primitive society.“ In Rationality, ed. B. Wilson, Basil Blackwell, Oxford, 1970, s. 78-112.

Winch, P. (2004): Idea sociální vědy a její vztah k filosofii. Centrum pro studium demokracie a kultury, Brno.

Wittgenstein, L. (1993a): Fỉlozofická zkoumání. Filozofický ústav AV ČR, Praha. 
Wittgenstein, L. (1993b): Philosophical occasions 1912-1951. Eds. J. Klagge \& A. Nordmann, Hackett Publishing Co, Indianapolis.

Wittgenstein, L. (2007): Tractatus logico-philosophicus. OIKOYMENH, Praha.

Wittgenstein, L. (2010): Ojistotě. Academia, Praha.

\begin{abstract}
Application of the philosophy of late L. Wittgenstein in C. Geertz's work

The goal of the article is to analyze how Clifford Geertz applies L. Wittgenstein's late philosophy in the methodology of the social sciences. In his works, Geertz disagrees with the criticss of relativism in anthropology, although refuses to take the position of relativist or anti-relativist. He calls his position an anti anti-relativist. According to him, the main problem of both sides is the misconception of culture as a non-dynamic and closed whole, which results from the philosophical idea of "ideal" concepts. According to him, such an idea is particularly unsustainable in today's globalized interconnected world. On the contrary, he considers Wittgenstein's concept of "language game" to be a suitable methodological tool, which offers a view of language and culture as a network of similar practices, family resemblence that cannot be summarized in a number of premises and doesn't have clear boundaries.
\end{abstract}

Key words: anti anti-relativism, anthropology, language game, Wittgenstein, Geertz

Vejnbender, K. (2020): „Uplatnění pozdní filozofie L. Wittgensteina v myšlení C. Geertze." Filosofie dnes 12 (2): 20-40. Dostupné z www.filosofiednes.ff.uhk.cz 


\section{Filosofická praxe v České republice}

\author{
Lukáš Mareš \\ Teologická fakulta \\ Jihočeská univerzita \\ v Českých Budějovicích \\ Branišovská 1645/31, 37005 \\ České Budějovice \\ mares103@tf.jcu.cz
}

\author{
Václav Peltan \\ Teologická fakulta \\ Jihočeská univerzita \\ $v$ Českých Budějovicích \\ Branišovská 1645/31, 37005 \\ České Budějovice \\ peltav00@tf.jcu.cz
}

\author{
Eliška Havlová \\ Pedagogická fakulta \\ Jihočeská univerzita v Českých Budějovicích \\ Branišovská 1645/31, 37005 České Budějovice \\ havlova.eli@gmail.com
}

Pojem filosofie nabyl v průběhu historie řadu podob a významů. Kromě tradičního teoretického zaměření se lze setkat s př́stupem, který vyzdvihuje praktický dopad filosofování na život člověka. Příspěvek představuje koncept filosofické praxe a reflektuje její současný stav na území České republiky. Autoři vymezují filosofickou praxi jako disciplínu filosofie a načrtávají její možné dělení na dílčí oblasti. Nastíněny jsou její historické kořeny, které autoři identifikují v antickém Řecku. Dále se věnují systematickému představení doposud sepsaných materiálů k filosofické praxi a přehledu její realizace na území České republiky. Detailní pozornost věnují autoři popisu tří jejích oblastí, mezi které patří filosofie pro děti ( $\mathrm{P} 4 \mathrm{C})$, filosofický workshop a filosofická konzultace. Kromě teoretického vymezení reflektují rovněž své vlastní postupy v uvedených oblastech. Text čerpá především ze zahraniční odborné literatury, konkrétně z textů a dalších materiálů filosofických praktikantů. Jeho cílem je představit českému čtenáři doposud podrobněji neřešený koncept filosofické praxe, a připravit tak pole pro možnou akademickou diskusi.

Kličová slova: filosofická praxe, dialog, filosofie pro děti, P4C, filosofický workshop, filosofická konzultace 


\section{1. Úvod - Vymezení filosofické praxe}

Co je to filosofická praxe? Zmíněné sousloví se v odborné literatuře objevuje poměrně krátce a nutno dodat, že vzbuzuje rozpaky. Paradoxní je na tom fakt, že se často pojí neshody s tímto souslovím i uvnitř samotné filosofické praxe. Text představuje filosofickou praxi jako odvětví či disciplínu filosofie, která se v mnohém dotýká rovněž pedagogiky a psychologie. Zařazení do oblasti filosofie zdůvodňujeme především užívanými metodami, cíli, rovinami a odkazy na filosofickou tradici (zejména důrazem na texty a myšlenky autorů-filosofü). Velká část kritiky zaznívá nejen z úst psychoterapeutů, ale i z řad samotných filosofü. Nejprve je ale zapotřebí si dostatečně vyjasnit všechny jednotlivé podoblasti filosofické praxe, do kterých spadá mnoho prŕbuzných aktivit, technik a inspirací. Pokusíme se navrhnout systematické rozlišení doposud nevyjasněné terminologie, ukázat historické kořeny filosofické praxe, představit současný stav bádání a realizace v českém prostředí a rovněž seznámit čtenáře se třemi základními oblastmi, kterými jsou filosofie pro děti ( $\mathrm{P} 4 \mathrm{C})$, filosofický workshop a filosofická konzultace.

Pojem „filosofická praxe“ chápeme jako název odvětví filosofie, ${ }^{1}$ které se od 80. let 20. stoletín začíná postupně etablovat a získávat celosvětový vliv. Zároveň se také podle nás jedná o nadřazený pojem, který zaštituje veškeré formy setkávání filosofických praktikantů s účastníky různých věkových skupin (viz obr. 1). Filosofická praxe, jak už je z jejího názvu patrné, se snaží filosofii přenést do praxe. Tento obrat lze ilustrovat takto: Jako by sami filosofové zapomínali na praktické důsledky svých činů a myšlenek ve světě a chtěli být „zase“ nápomocni lidem k lepšímu chápání sebe samých a světa kolem nich tak, jako tomu bylo v antické filosofii (s odkazem na její interpretaci podle P. Hadota ${ }^{3}$ ). Tento pedagogicko-psychologický motiv neustále vystupuje $\mathrm{v}$ historii filosofie

\footnotetext{
1 Vedle filosofie teoretické (metafyzika), praktické (etika, ale i např. filosofie výchovy), aplikované a experimentální (systematické experimenty, které mají za cíl poskytnout hlubší vhled do toho, jak lidé běžně přemýšlejí o problémech s filosofickým kontextem).

2 Začátek filosofické praxe jakožto hnutí se obvykle pojí s osobou německého filosofa G. Achenbacha (narozen 1947), který si v roce 1982 založil v Německu Gesellschaft für Philosophische Praxis. Viz Šulavík (2001).

3 P. Hadot (1922-2010) byl francouzský filosof, který se věnoval neoplatonismu a historii filosofie. Slavný se stal kvůli své interpretaci antické filosofie jako způsobu života. Viz Hadot (1995a, 1995b, 2012).
} 
jako klíčový pro ni samou (J. Patočka, J. Pešková ad.). Jakožto filosofové ovšem musíme mít neustále na paměti jedno z největších úskalí tohoto obratu, který popsal Platón v Ústavě (podobenství o jeskyni), ${ }^{4}$ totiž úskalí neúspěchu a nepochopení filosofa. Na konci 20. století se objevuje hnutí a myslitelé, kteří chtějí dělat filosofii jinak, prakticky a s přesahem k lidem (nefilosofům). Problémem může být nepochopení, ale i nesystematičnost, neprofesionalita a nízká odbornost filosofických praktikantů ${ }^{5}$.

Naše chápání filosofické praxe bychom mohli načrtnout takto:

\section{Filosofická praxe}

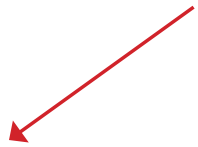

Individuální rovina

Filosofické konzultace

Filosofické poradenství

Filosofický koučink

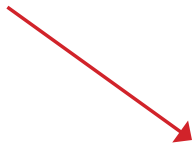

Skupinová rovina

Filosofické workshopy

Filosofie pro děti (P4C)

Obr. 1.

Filosofická praxe se tedy dělí na dvě základní skupiny. Na individuální rovině se dělí na filosofické konzultace, filosofické poradenství a filosofický koučink. Na skupinové rovině se dělí na filosofické workshopy a filosofii pro děti. Práce se skupinou v rámci filosofické praxe se většinou děje právě ve výše zmíněných rovinách, které je dle nás důležité rozlišovat. Pokud filosofický praktikant pracuje s dětmi, je velmi pravděpodobné, že jeho aktivity budou velmi blízké konceptu filosofie pro děti. Pokud pracuje $\mathrm{s}$ dospívajícími či dospělými lidmi, jedná se o filosofický workshop. Na individuální rovině pak rozlišujeme v zásadě mezi konzultací a poradenstvím, a to podle míry filosofického obsahu, používaných nástrojů a blízkosti $\mathrm{k}$ oblasti psychologie. Poradenství chápeme jako oblast patřící spíše do oblasti psychologie, zatímco konzultace svou povahou, formami a obsahem splňuje nároky svébytné

4 Viz Platónova Ústava, Platón (2003, 514b-541b).

5 Tímto pojmem označujeme člověka, který se věnuje jedné či více oblastem filosofické praxe. 
filosofické oblasti. Filosofický koučink je možné vymezit jako techniku práce na rozvoji myšlenkových dovedností a postojů, a to při využití textů či různých cvičení. ${ }^{6} \mathrm{~V}$ současnosti představuje spíše marginální oblast filosofické praxe, a z tohoto důvodu mu v příspěvku nevěnujeme bližší pozornost. $\mathrm{V}$ textu představujeme tři oblasti filosofické praxe, kterým se aktivně věnujeme, považujeme je za filosofické a již etablované.

\section{Historické kořeny filosofické praxe}

Kořeny filosofické praxe nacházíme v antickém Řecku, které bývá zároveň označováno za kolébku filosofie jako takové. Již u předsókratovských myslitelů (napřr. Démokritos) se lze setkat $\mathrm{s}$ rozpracováním etiky a otázkami týkajícími se vedení dobrého života, avšak dochované prameny jsou spíše sporadické. Od doby Sókrata, Platóna a následně Aristotela (5. -4. stol. př. n. 1.) do popředí výrazněji vystupuje důraz na praktický dopad filosofování na život člověka a starání se o duševní život. Uvedené období je proto možné označit za počátek psychologie. Jak uvádí M. Nakonečný, „Filosofické úvahy o duševním životě člověka a o duši a také zkoumání duševního života sebepozorováním a pozorováním druhých lidí ... nacházíme již u starých řeckých filosofů." "7

Pojetí antické filosofie jako životní cesty či osobního hledání a sebetransformace prezentuje P. Hadot či J. M. Cooper. Hadot uvádí, že na počátku filosofování stojí přinejmenším od dob Sókratových otázka volby způsobu života. Filosofický diskurz ${ }^{8}$ začíná u existenciální volby, je vázán na konkrétní školu myšlení a podporuje ji. Filosofická škola znamená právě toto rozhodnutí, které od jedince požaduje zásadní životní změnu, bytostnou transformaci a je v posledku vyjádřením touhy pobývat ve světě určitým způsobem. ${ }^{9}$ Filosofických škol, a tedy i diskurzů, bylo v antice veliké množství, nicméně společným prvkem

6 Pro více informací viz stránku filosofických praktikantů O. Brenifiera a J. Lecoqa: Lecoq, J. (2019a): „Philosophical coaching.“ In Dialogon [Online] Paris, C) 2019 [cit. 4. 4. 2020]. Dostupné z: http://dialogon-en.ugal.com/philosophical-coaching.

7 Viz Nakonečný (2015, s. 14).

8 Hadot tímto pojmem myslí diskurzivní uvažování ve filosofickém smyslu, vyjádřené formou psanou či ústní.

9 Viz Hadot (1995b, česky 2017 s. 15-17). 
byla dle Hadota snaha vést zdařilý život a dosahovat životní moudrosti. ${ }^{10}$ Toho bylo dosahováno nejen teoretickým zkoumáním reality (Aristotelés), získáváním vědění o světě a sobě samém (Sókratés, Platón), ale $\mathrm{v}$ helénistickém období i praktickými návody na žití a duchovními cvičeními ${ }^{11}$ (např. epikureismus, stoicismus či kynismus).

Jednou z nejinspirativnějších postav pro filosofickou praxi je Sókratés. Jeho metoda dialogického zkoumání (exetazein) ${ }^{12}$, kterou uplatňoval při rozhovorech s athénskými občany, spočívala ve zkoumání názorů druhých, v odkrývání složitosti problémů a v hledání správného uchopení pojmů (hledání odpovědí na otázku „Co je...?"). ${ }^{13}$ Sókratés usvědčoval své spoluobčany z nevědomosti o záležitostech, o kterých původně tvrdili, že je znají (metoda elenchos). ${ }^{14}$ Rovněž se je ovšem pomocí otázek snažil přimět k „porodu“ myšlenek a určitému „zvědomění“ jejich přesvědčení tak, aby bylo zřejmé a dalo se s ním v rámci filosofického rozhovoru následně pracovat (maieutická metoda). ${ }^{15}$ Sókratés tak pomocí otázek vedl lidi k tomu, aby zkoumali sebe sama, poznávali podstatu věcí, starali se o vlastní duši, kultivovali se jako osobnosti a žili ctnostně. V Apologii dává Platón do úst Sókratovi výrok „,... život bez zkoušení není člověku hoden žití..."16 Právě důrazem na zkoumání sebe sama a vlastního života společně s důrazem na vedení zdařilého života představuje Sókratés významný inspirační zdroj pro oblast filosofické praxe.

10 Filosof v období antiky je dle Hadota nicméně oproti ostatním občanům chápán jako bytost zvláštní a podivínská, jelikož se rozchází se zvyklostmi a obyčeji běžných smrtelníků. Viz Hadot (2012, česky 2019, s. 21).

11 Hadot tímto výrazem míní různé praktiky charakteru tělesného, jako je například stravovací režim, řádu diskurzivního, jako je dialog či rozvažování, anebo řádu intuitivního, jako je kontemplace. Jejich společným cílem je dosáhnout vnitřní proměny toho, kdo se jim věnuje. Viz Hadot (2012, česky 2019, s. 17).

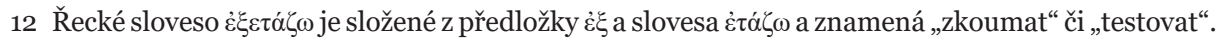
Etymologicky se jedná o denominativum (tj. slovo odvozené od podstatného nebo př́davného

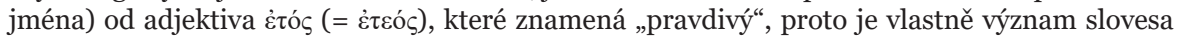

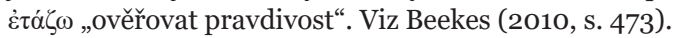

13 Viz Irwin (2007, s. 121).

14 Metoda spočívá v demonstraci kontradikce a v jakémsi odmaskování dotazovaného od nánosů jeho klamných názorů.

15 Dle sókratovsko-platónské tradice člověk v sobě jaksi má vědění a v průběhu života si na ně pomocí různých technik i kontextů rozpomíná (anamnésis). Maieutická metoda je spíše pozitivní projekt, ve kterém jde o to zvědomovat a formulovat vědění spíše než ho zpochybňovat.

16 Viz Platón (2005, 38a). 
Kořeny a ideové ukotvení filosofické praxe $\mathrm{v}$ českém prostředí lze hledat u tzv. filosofie provádějící. Spolu s N. Pelcovou ji můžeme charakterizovat jako filosofii, ,jejímž cílem je kultivovat, proměňovat a vychovávat člověka, pěstovat jeho lidské a občanské ctnosti, rozvíjet tvorbu ve vztahu ke světu a sebetvorbu ve vztahu k sobě samému“. ${ }^{17}$ Patočka filosofií provádějící nazýval filosofii výchovy, s odkazem na Platóna to byla péče o duši člověka. ${ }^{18}$ Filosofickou praxi vnímáme jako na teoretické rovině velmi blízkou filosofii provádějící. Hlavní rozdíl spatřujeme v samotném provádění. Zatímco filosofie provádějící je pro člověka určitou oporou a průvodcem na jeho životní cestě a znamená v zásadě život ve zkoumání sebe sama (Sókratés), filosofická praxe je konkrétní realizací daného zkoumání, když používá specifické metody, nástroje a postupy, které člověka $\mathrm{k}$ tomuto cíli vedou. Mưžeme ji tedy označit za praktické vyústění filosofie provádějící.

\section{Filosofická praxe v ČR: dosavadní stav bádání a realizace}

Výzkum a samotná realizace filosofické praxe je v České republice na začátku. Existují studentské práce, které se věnují vybraným oblastem a tématům $\mathrm{z}$ dané disciplíny a které českému čtenáři představují myšlenky zahraničních filosofických praktikantů. Př́lkladem jsou bakalářská a diplomová práce I. Koptové (Filosofické poradenstuí, 2012; Co je specifické pro filosofické poradenství?, 2014), bakalářská práce T. Helmicha (Filosofická praxe a poradenství, 2013) či diplomová a disertační práce O. Horáka (Buberov koncept Ty ako spôsob života. Možnosti aplikácii vo filozofickom poradenstve a d'alších oboroch, 2010; Filozofické poradenstvo - kritika, 2014), která vyšla rovněž v podobě monografie. ${ }^{19} \mathrm{~J}$. Peregrin publikoval zprávu o filosofickém poradenství s názvem Filosofické poradenství, vzkvétající živnost. ${ }^{20}$

17 Pelcová (2020).

18 Viz Blecha (2015). Na práci J. Patočky navázala mj. filosofka J. Pešková, která zdůrazňovala nepostradatelnost filosofie pro náš život a v podobě filosofie provádějící ji aplikovala v běžném životě.

19 Viz Horák (2015). Publikaci je možné označit za selektivní kritiku filosofického poradenství, které autoři textu řadí k nejproblematičtějším oblastem filosofické praxe.

20 Viz Peregrin (2010). Spíše než seriózním vyjádřením k filosofické praxi je zpráva satirickým a ironizujícím vyjádřením k filosofickému poradenství. Mnohdy vtipným způsobem upozorňuje na nedostatky této kontroverzní oblasti filosofické praxe. 
Filosofické konzultaci ve sportu se věnoval ve svém prríspěvku L. Mareš. ${ }^{21}$ Postřehy a osobní zkušenosti s filosofickou praxí zpřístupňuje na svém blogu formou osobních zápisků D. D. Novotný. ${ }^{22}$

$S$ větším množstvím materiálů se lze setkat $\mathrm{v}$ případě filosofie pro děti (P4C). Jmenujme např́íklad bakalářskou práci L. Hubené (Srovnání př́stupu M. Lipmana a O. Brenifiera $k$ filosofování s dětmi, 2013), bakalářskou práci E. Brisudové (Filozofie pro děti jako součást rozvíjení myšlení a emoční inteligence dětí prèedškolního věku, 2016), bakalářskou práci J. Hořejší (Filozofie pro dětiv MŠ Větrná, 2018), diplomovou práci J. Vlasákové (Filozofie pro děti na 1. stupni ZŠ, 2012), diplomovou práci B. Odehnalové (Filosofie pro děti jako koncepce výuky náboženstuí a katecheze, 2016) či diplomovou práci V. Jozové (Filosofie pro děti jako prostředek etické výchovy zahrnující různé oblasti života dítěte $v$ mladším školním věku, 2018). Pod hlavičkou Jihočeské univerzity existuje Centrum Filozofie pro děti, které vydalo překlady metodických textů i vlastní texty pro filosofování s dětmi, pořádalo vzdělávací kurzy pro učitele a zprostředkovávalo setkání s odborníky v dané oblasti.. ${ }^{23}$

Výzkum v oblasti filosofické praxe probíhá rovněž na Slovensku. Zde je potřeba zmínit autory B. Šulavíkovou a J. Šulavíka, kteří svými odbornými př́íspěvky zprostředkovávají vhled především do oblasti filosofického poradenství. Reflektujeme-li však samotnou realizaci filosofické praxe na území Česka či Slovenska, lze konstatovat, že se jedná prozatím o ojedinělý fenomén. Aktivně rozvíjet filosofickou praxi se pokoušejí autoři tohoto př́spěvku. Od dubna 2017 pořádají na Teologické fakultě Jihočeské univerzity pravidelně filosofické workshopy určené pro studenty, akademické pracovníky i širokou veřejnost. Rovněž navštěvují základní a střední školy v Českých Budějovicích a blízkém okolí, kde filosofují se studenty nad vybranými tématy. Této iniciativě se věnují také na univerzitě, a to v rámci projektu Dětské a Juniorské univerzity. ${ }^{24}$

21 Viz Mareš (2019).

22 Pro více informací viz Novotný, D. D. Poznámky pod čarou. Analyticko-scholastické drobky postmoderního tradicionalisty [Online]. Hledat: „filosofická praxe“ [cit. 13. 1. 2020]. Dostupné na: http://poznamkypodcarou.blogspot.com/search/label/filosofick\%C3\%A1\%2opraxe.

23 Pro více informací viz Centrum Filozofie pro děti. Filosofie pro děti. V centru pozornosti ... myšLenka. [Online]. Jihočeská univerzita $v$ Českých Budějovicích, Katedra pedagogiky TF, České Budějovice [cit. 31.1. 2020]. Dostupné na: http://www.p4c.cz/.

24 Jedná se o celouniverzitní projekt, který se snaží žáky a studenty vtáhnout do univerzitního 
Mimoto nabízejí studentům a zaměstnancům Jihočeské univerzity možnost absolvovat filosofickou konzultaci. ${ }^{25}$ Autoři neznají nikoho dalšího, kdo by v současnosti filosofickou praxi (vyjma filosofie pro děti) systematicky na území České republiky provozoval. Objevují se semináře či kurzy, které mají k probírané disciplíně minimálně blízko (nap̌r. rozvoj kritického myšlení, semináře a společná čtení v kavárnách, filosofické rozpravy studentů a vyučujících jako doplňkové semináře), žádná z těchto událostí se ovšem k filosofické praxi explicitně nehlásí a neodkazuje přímo k metodám jejích zástupců.

\section{Filosofie pro děti}

Program filosofie pro děti založil americký filosof M. Lipman ${ }^{26}$ (19232010). Jeho snaha cílila na to, aby děti ve škole byly schopné lépe argumentovat, reagovat na druhé a klást si otázky. Filosofie pro děti, tak jak ji chápeme v tomto textu, však není pouze Lipmanovou metodou. ${ }^{27}$ Lipman však nejlépe vycítil onu potřebu, která se v jeho době a v jeho pedagogické praxi ukazovala jako důležitá. Mnoho zástupců filosofické praxe pracuje kromě dospělých a dospívajících také s dětmi. Např. O. Brenifier, ${ }^{28}$ známý francouzský filosofický praktikant, má oproti Lipmanovi odlišnou metodu práce s dětmi, ve které vystupuje více do popředí spíše jedinec než skupina. Důležité je také zmínit, že právě u dětí je velký transformující a obohacující potenciál v jejich vlastním myšlení - mohou se naučit tázat, hledat odpovědi a naslouchat druhým, což je pro jejich další rozvoj podstatné.

dění a zprostředkovat jim akademická témata dostupným způsobem. Viz Teologická fakulta, Jihočeská univerzita $v$ Českých Budějovicích [Online]. (C)2020 [cit. 31. 5. 2020]. Sekce „Podrobné informace o kurzech“ Dostupné z: https://www.tf.jcu.cz/zajemci-o-studium/ celozivotni-vzdelavani/podrobne-informace-ke-kurzum.

25 K začátku roku 2020 uskutečnili autoři textu přes 40 workshopů s dětmi, studenty a dospělými. Rovněž dohromady vedli přes 10 filosofických konzultací se studenty univerzity a jejími pracovníky či absolventy.

26 M. Lipman spolu s A. M. Sharp vymyslel a dále rozvíjel pedagogickou metodu filosofie pro děti. Jako začátek této tendence můžeme datovat vydání filosofického příběhu Harry Stottlemeier's Discovery v roce 1971.

27 Filosofování s dětmi se věnují rovněž B. Børresen a B. Malmhester či S. Stanley.

28 Viz „Philosophy with children.“ In Institute de Practiques Philosophiques [Online] [cit. 23. 1. 2020]. Dostupné na: http://www.pratiques-philosophiques.fr/en/pratical/philosophy-withchildren. 
Obecně lze říci, že filosofie pro děti vypadá v praxi tak, že děti obvykle sedí v kruhu, který symbolizuje rovné př́ležitosti a napomáhá lepší komunikaci jak akustické, tak vizuální. Na začátku se čte příběh. Děti se tak zdokonalují nejen ve čtení, kdy každé z nich čte jednu větu nebo část textu, ale i v naslouchání druhým. Filosofické příběhy často obsahují postavy a témata, která vyvolávají otázky. Po přečtení určité části knihy pokládají děti otázku, která souvisí přímo s textem, nebo nějak vychází z jejich vnímání textu. Při této fázi je zásadní, aby se tvořily otázky filosofické, ne triviální. Poté se demokraticky volí otázka, která se bude probírat. Následující diskuse, která v důsledku nemá být pouze diskusí, ale také dialogem, je stěžejní částí každé filosofie pro děti. Tato část nejde připravit, předpovědět či upravovat tak, jak bychom dopředu zamýšleli. Je důležitá zejména kvo̊li tomu, že je to prostor, ve kterém filosofujeme - snažíme se vyřešit spolu s druhými nějakou otázku či problém. V závěrečné (reflexivní) části by mělo dítě zhodnotit své dosavadní myšlení (jeho vývoj), názory druhých, ale také přípravu a průběh cvičení samého. Hodina filosofie pro děti má určitou strukturu. Nejčastěji se jedná o tři podstatné části (aktivizace, otázky, dialog/diskuse), které bývají dále upravovány či opakovány v návaznosti na danou větev filosofie pro děti.

Základním cílem filosofie pro děti je dle M. Lipmana rozvoj myšlení. To se děje na třech úrovních. První je tvořivé (kreativní) myšlení, které hledá alternativy, důsledky, analogie a vztahy. Druhé je kritické myšlení, které vyvozuje, hlídá samo sebe (tzv. autokorekce), hledá kritéria situace a její východiska. Poslední je myšlení angažované, které ověřuje hypotézy, definuje pojmy či s odstupem a z jiného úhlu na věc pohlíží. ${ }^{29}$ Dále se v dětech probouzí zásady argumentace při diskusi a dialogu s druhými stejně tak, jako se zlepšuje cit pro komunikaci jako takovou v její verbální i neverbální formě. A tak se například děti učí nejenom mluvit a naslouchat, ale i mlčet nebo se nebát promluvit, pomoci druhému a nebo se nebát zeptat, když druhému nerozumíme (mějme však na paměti, že rozumět neznamená souhlasit). Dítě tak získává klíčové kompetence, které může využít i mimo hodinu filosofie a trrídu.

29 Viz Centrum Filozofie pro děti (2O2O). 
M. Lipman chce, v návaznosti na J. Deweyho, přeměnit školní třídu v hledající společenství či zkoumající komunitu (community of inquiry). ${ }^{30}$ Jedná se o situaci, kdy děti společně hledají pravdu na jimi vybranou otázku. Především jde o vzájemné naslouchání, vyměňování názorů a hledání řešení. Ten, kdo danou skupinu vede, by měl vystupovat v roli facilitátora a měl by být spíše součástí skupiny než garantem pravdy či někým, kdo stojí striktně mimo ostatní. Jeho úkol je zapisovat myšlenky na tabuli, rekapitulovat řečené, pokládat dílčí otázky, upozorňovat na předpoklady a protiřečení apod.

Filosofické příběhy, které se využívají ve filosofii pro děti, mají dát dostatečný literární (narativní) prostor pro filosofování s dětmi. Aby byl prostor také filosofický, musí být takový, aby oslovil děti a podnítil je k tázání. Musí být dítěti blízký. Nemá se jednat o pohádku či o naprostou fikci. Reálné postavy řeší (reálné) problémy a sami hledají odpověd' na své otázky. Příběh by měl obsahovat filosofická témata, nejednoznačné otázky, situace a dialogy postav. V dnešní situaci ovšem v rámci filosofie pro děti lze využít i knihy, které nejsou pouze filosofickými příběhy. Jedná se především o obrázkové knihy různých spisovatelů a ilustrátorů. ${ }^{31}$

\section{Filosofický workshop}

Filosofický workshop je společná aktivita zaměřená na filosofické přemýšlení, porozumění určitému tématu a na individuální i skupinový myšlenkový rozvoj. Na rozdíl od konzultací probíhá ve větším počtu účastníků (obvykle mezi 5 a 20 lidmi). Během workshopu se filosofickým způsobem řeší atraktivní a důležitá témata. ${ }^{32}$ Tematicky není workshop omezen. Za hlavního garanta a vodítko rozhovorů je obvykle považována racionalita.

30 J. Dewey (1859-1952) spolu s C. S. Peircem (1839-1914) jako první zavedli pojem community of inquiry. Pro kontext v programu filosofie pro děti viz Lipman (1993, s. 606-614).

31 Filosofické příběhy (povídky) známých propagátorů filosofie pro děti byly přeloženy do českého jazyka díky Centru filozofie pro děti (při Teologické fakultě Jihočeské univerzity v Českých Budějovicích), zmiňme např. Sharp (2000, 2005).

32 Mezi témata, která jsme doposud s účastníky řešili, patří: politická filosofie („Je demokracie nejlepší způsob vlády?“, „Jsme národní stát?“), „Co má v životě smysl?“, „Člověk a jeho nábožensko-mytologický výklad skutečnosti“, „Sókratés“, „Čas“, „Jíst, či nejíst maso?“, „Filosofování o sportu“, „Hodnota peněz“, „Jaká je dnešní doba?“, „K čemu poznávat sám sebe?“, „Odpouštět, či neodpouštět?“, „Odpovědnost za přírodu“, „Etická dilemata“ ad. 
Filosofický workshop se zaměřuje na rozvoj porozumění určité oblasti včetně tázajícího se člověka a na pravdivé uchopování skutečnosti. Zaměřuje se ale také na rozvoj tzv. měkkých dovedností. Mezi ně řadíme racionální uvažování, kooperaci, sebereflexi, tvůrčí řešení problémů, strukturované myšlení, konstruktivní kritičnost a schopnost přijímat kritiku, schopnost adaptace, samostatnost, orientaci v informacích, morální reflexi, ale i schopnost aktivně naslouchat a reagovat na řečené spíše než na domyšlené a zkreslené. Ve filosofickém workshopu se člověk učí koexistenci založené na toleranci, vzájemném respektu, odpovědnosti a nediskriminaci. Učí se rozvíjet to, co považujeme za bytostně lidské, tedy schopnost vedení dialogu. Ten zahrnuje schopnost naslouchat, adekvátně reagovat na řečené, ale i formulovat vlastní přesvědčení a rozumově ho podložit. $V$ rámci filosofického workshopu se lidé učí přemýšlet filosofickým způsobem, tj. učí se rozumově uchopovat konkrétní téma. Jelikož je workshop postaven na skupinovém dialogu ${ }^{33}$, rozvijí u účastníků rovněž schopnost prezentovat své myšlenky ve skupině, adekvátně reagovat na druhého a orientovat se ve skupinovém rozhovoru.

Vedoucím workshopu je facilitátor (obvykle 1 až 3 lidé), jehož role se liší podle cíle workshopu. Jeho základní úlohou je naplánovat a představit rámec workshopu, řídit či korigovat rozhovory, zapisovat myšlenky účastníků a vhodně je vyzdvihovat. Existuje více přistupů k filosofickým workshopům. Naše metoda je umírněná verze filosofického workshopu O. Brenifiera ${ }^{34}$ doplněná o určité prvky z filosofie pro děti (Lipman, Børresen, Malmehester). ${ }^{35}$

Filosofický workshop, na rozdíl od filosofie pro děti v lipmanovském duchu či filosofování s dětmi v podání O. Brenifiera, přesahuje školní prostředí. Oproti filosofickému workshopu je filosofie pro děti zaměřena na práci s mladšími dětmi a na osvojování si základních myšlenkových

33 Jedná se o takový typ rozhovoru, kdy účastníky spojuje konkrétní téma, o kterém hovoří, a zároveň dodržují obecná pravidla dialogu, jakými jsou ochota naslouchat, porozumět, podrobit kritickému zkoumání vlastní přesvědčení a snaha přispět k porozumění určitému tématu či navrhnout řešení (nikoli vyhrát spor).

34 Viz Brenifier (The Art of Philosophical Practice).

35 Se zmíněnými praktikanty mají autoři praktickou zkušenost díky návštěvě jejich seminářů a rovněž díky studiu textů a jejich aplikaci do praxe. 
dovedností. Filosofický workshop stojí na filosofických základech, resp.je důslednější, náročnější a využívá pestřejší paletu nástrojů a dovedností. Rozvíjí osobnost člověka pro život díky používání filosofických nástrojů a je obvykle určen pro dospělé lidi. ${ }^{36}$ Ve filosofii pro děti je kladen větší důraz na aktivizaci skupiny (stimulující aktivity i nefilosofického charakteru) a na propojení se skupinou. Vefilosofickém workshopujevětší důraz kladen na proces přemýšlení - tj. na správné užívání filosofických nástrojů $\mathrm{v}$ podobě konceptualizace, argumentace, problematizace, syntézy, tvorby myšlenkových experimentů, interpretace, evaluace či reflexe a na pohybování se na filosofických rovinách (abstraktní/obecné, kritické a tematicky otevřené).

$\mathrm{V}$ př́padě lipmanovského př́stupu se facilitátor stará o to, aby se skupina jako celek posouvala kupředu v řešení otázky, aby důležité myšlenky nezapadávaly a zapojovali se pokud možno všichni. Používá přitom sumarizaci, reflexi a pestrou sérii otázek. Ideálem je, že skupina po čase řídí workshop do velké míry sama a facilitátor se stává jedním z účastníků. Dalším ideálem workshopu je to, když skupina usilovně přemýšlí a facilitátor není bezprostředně zaneprázdněn myšlenkovým úsilím, takže má kapacitu na sledování dění z dostatečného odstupu na to, aby dokázal rozpoznat zacyklenost či dokázal přijít s konstruktivním nápadem.

V rámci brenifierovského př́stupu se facilitátor snaží o individuální rozvoj určitého člena skupiny (případně více členů). Smyslem není až tak společné hledání, ale individuální posun a určité prozření účastníků. Facilitátor $\mathrm{v}$ rámci workshopu $\mathrm{v}$ tomto případě volí strategii dílčích konzultací, je přímočarý, dbá na koherentnost a stručnost výpovědí a použíá skupinu jako nástroj pro demonstraci „selského rozumu“ (common sense). ${ }^{37}$ Je autoritou, která drží otěže workshopu ve svých

36 Lze říci, že pro jedince od věku střední školy, kteři jsou schopni komplexněji a abstraktně přemýšlet.

37 Koncept common sense (zdravý, selský či přirozený rozum) je vhodným nástrojem pro demonstraci sdílené racionality/objektivity a pro eliminaci osobních myšlenkových výstřelků. Jeho rizikem, na které upozorňuje např. S. Hawking (Brief Answers to the Big Questions) je to, že pracuje s momentálním chápáním toho, co je přijímáno jako racionální, a neumožňuje tak myšlenkovou kreativitu, která začíná obvykle v iracionalitě a vede k vytvoření nové racionality. Argument proti této námitce může být to, že common sense je v zásadě neměnný a použitelný ve stejné podobě i v odlišných kontextech, tj. odkazuje $\mathrm{k}$ těm nejzákladnějším mechanismům $\mathrm{v}$ realitě a v naší mysli. 
rukou. Během workshopu je kladen důraz na to, jak lidé přemýšlejí, nikoli na to, co si myslí - obsah je tedy řazen na druhou kolej. ${ }^{38}$ Skupina se využívá jako zrcadlo a nástroj pro formování jednotlivce a pro demonstraci jeho myšlení. Pracuje se na postojích (attitudes) a kompetencích (competencies). ${ }^{39} \mathrm{~V}$ této formě vedení skupiny je facilitátor i konfrontační, a to s cílem nastavit jednotlivému účastníkovi workshopu zrcadlo, aby v něm viděl sebe samého. $4^{40}$

$\mathrm{Na}$ našich workshopech, pořádaných na Teologické fakultě JU, se zaměřujeme především na skupinovou práci, která má vyústit ve schopnosti lépe argumentovat, ujasňovat si pojmy a přiblížit se odpovědi na probíraný problém či otázku. Téma workshopu je obvykle předem dané a jako facilitátoři navrhujeme i metodický postup pro jeho řešení. Zůstáváme ovšem otevřeni návrhům na změnu ze strany účastníků. Oproti brenifierovskému přístupu klademe větší důraz na práci s filosofickým obsahem než na práci s postoji účastníků. Hledání odpovědi nemusí být vždy jednoduchý, jednomyslný a krátký proces, ale přesto se jedná o nejzákladnější filosofickou dovednost - tázat se a pokoušet se odpovídat. Neméně důležitou součástí je i naslouchání a porozumění tomu, co druhý říká. Při workshopech využiváme také metody zážitkové pedagogiky, psychologie, koučinku či dalších př́ibuzných oblastí. Jedním z dalších cílu je také poznávat jiné (lidi, argumenty, procesy myšlení), což může pomoci pochopit jak ostatní účastníky, tak v konfrontaci s jinakostí i sebe sama. Filosofický workshop lze vnímat jako určitou „oázu“ určenou pro důsledné přemýšlení, která je na jedné straně oddělena od každodenní reality, na druhé straně ji má jako předmět svého zájmu a z odstupu ji reflektuje.

38 Námitkou zde může být, zda je při nedostatečném zohledňování obsahu možné hovořit o workshopu jako o filosofickém.

39 Viz videorozhovor s V. Chernenko, ruskou filosofickou praktikantkou patřící do brenifierovské školy filosofické praxe: Lahav (2014).

40 Tato forma vedení je blízká vedení polemiky, např. při politických debatách, kdy je cílem zjistit přesvědčení druhých, případně i poukázat na nekoherentnost či nejasnost myšlení druhého. Moderátor veřejných debat oproti tomuto přístupu spíše dbá na vytvoření př́ijemného a bezpečného prostředí, pomáhá mluvčím se smysluplně a konstruktivně vyjadřovat a dbá na plynulý chod debaty. Tímto svým přístupem se spíše blíží lipmanovskému přístupu. 


\section{Filosofická konzultace}

Zatímco filosofická praxe jako celek vychází z antické tradice, kritéria vymezení filosofické konzultace by měla být odvozována především z doby současné a reagovat na vědecké poznání oborů, jako je např́íklad psychologie, která byla ještě do 19 . století $^{41}$ považována za součást filosofie. Za takové kritérium považujeme filosofičnost, ptáme se, co zbylo filosofii, když se z ní vydělily specializované vědy, co je na filosofické konzultaci filosofického? Filosofická by měla být jak forma, tak i obsah konzultace. Považujeme za důležité zdůraznit, že filosofie v jakékoliv formě není pomáhající profesí. ${ }^{42}$ Filosofie sama ani filosofické konzultace nemohou ze své podstaty zaručit a ani tedy slíbit člověku takovou pomoc, jakou nabízí například psychoterapeut, sociální pracovník nebo lékař. Filosofická konzultace nemá za cíl člověku pomoci cítit se lépe nebo vyřešit nějaký osobní problém, to se však může stát náhodným nebo vedlejším produktem. J. Šulavík, který se vyjadřuje $k$ terapeutickému efektu filosofické interpretace, píše, že tento efekt není primárním cílem filosofie, ale sekundárním důsledkem její celkové kognitivní aktivity. ${ }^{43}$

Filosofickou pomoc naopak slibuje filosofické poradenství, ${ }^{44}$ které $\mathrm{v}$ širším pojetí dokonce zahrnuje i pomoc $\mathrm{s}$ duševními onemocněními. 45 Filosofické poradenství kritizuje O. Horák, který popisuje jeho rizika pro klienty, kteří se svěřují do péče filosofưm bez adekvátního vzdělání v psychologii nebo psychiatrii a riskují tak své duševní zdraví v rukou člověka, který vede poradenské sezení převážně podle své intuice a na základě technik bez empirické evidence. ${ }^{46}$ Je doporučeno, aby každý filosofický konzultant měl minimálně magisterské vzdělání ve filosofii. ${ }^{47}$

41 Viz Nakonečný (1995).

42 Tímto výrokem míníme, že ačkoli filosofie člověku určitým způsobem pomoci může (např. porozumět určitému tématu, rozvíjet myšlenkové dovednosti či získat vědění), ze své podstaty není jejím cílem pomáhat způsobem, jakým pomáhají profese k tomuto účelu zaměřené.

43 Viz Šulavík (2001, s. 588).

44 Mezi nejznámější filosofické poradce patří L. Marinoff, P. B. Raabe či S. Schuster. Z organizací stojí za zmínku American Philosophical Counseling Asociation (APCA) či American Philosophical Practicioners Asociation (APPA) či American Society for Philosophy, Counseling, and Psychotherapy (ASPCP).

45 Viz Louw (2013, s. 64).

46 Viz Horák (2015, s. 46).

47 NPCA (2014). 
Také by měl být vybaven vlastnostmi vhodnými pro práci s klientem v dialogu, jakými jsou otevřenost, schopnost naslouchat, pohotovost, důslednost, pozornost. Konzultant by také měl mít alespoň základní znalost člověka z psychologického hlediska, aby rozuměl dopadu jeho působení na psychiku klienta a $\mathrm{v}$ př́padě potřeby doporučil klienta kompetentnějšímu odborníkovi.

Filosofie není pomáhající profesí, to ale neznamená, že vůbec nepomáhá. Pomáhá člověku projasňovat myšlení, prohlubovat porozumění určitému tématu, měnit životní perspektivy, hlouběji si uvědomovat souvislosti a stimulovat $\mathrm{k}$ důslednému přemýšlení o tématech na filosofické rovině. Konzultace je cvičením v přemýšlení. Filosoficky přemýšlet znamená racionálně reflektovat skutečnost z odstupu za využití určitých myšlenkových operací. Mezi ně patří argumentace, uvádění př́kladů, analýza, problematizace, konceptualizace, tvorba hypotéz či klarifikace. Argumentací rozumíme logicky platné zdůvodňování tvrzení. ${ }^{8}$ Analýzou myslíme důsledné zkoumání problému a zohledňování perspektiv. Problematizace představuje hledání limitů tvrzení. Konceptualizace je uchopování řešeného problému pomocí konceptu. Tvorbou hypotéz rozumíme formulaci předběžných racionálních odpovědí, které následně vybízejí k prověření a argumentačnímu podložení. Klarifikace je proces, kdy klient reformuluje své tvrzení za účelem jeho projasnění.

Ve filosofické konzultaci se proces rozhovoru odehrává ve formě dialogu. ${ }^{49}$ Př́ístupů $\mathrm{k}$ filosofickým konzultacím nebo filosofickému poradenství je dnes celá řada a liší se svou formou, obsahem i cíli. Následující popis zachycuje podobu konzultace, kterou se pokoušíme rozvíjet. Filosofický dialog probíhá mezi konzultantem a klientem. Dialog je zahájen tím, že klient položí jasně formulovanou otázku, která prezentuje filosofický problém či dilema. Od otázky se celá konzultace odvíjí a jejím vyřešením je konzultace uzavřena. Otázka se zpravidla zapisuje, aby se $\mathrm{k}$ ní během konzultace bylo možné vracet. Je totiž možné, že se během dialogu pozornost obrátí k jinému tématu. Zapsání

48 Viz Novák \& Dvořák (2007, s. 141).

49 Zahrnuje tedy otevřenost, aktivní snahu porozumět, společně tvořit v procesu vzájemné podpory i kritického náhledu, a to s důsledným následováním přirozeného rozumu. Nejedná se o rozhovor s cílem porazit druhého (debata), obhájit vlastní přesvědčení (disputace), ani o volné povídání bez cíle a pravidel (volná diskuse). 
otázky také slouží klientovi k tomu, aby si ujasnil, na co se chce zeptat, a svůj zájem na papíre ve formě otázky ohraničil. Jedná se o úvodní konceptualizující a klarifikující cvičení. Vyřešení dané otázky znamená, že klient dané téma promyslí takovým způsobem, že mu bude lépe rozumět a že odpovědi, které během konzultace nalezne, ho budou stimulovat k dalšímu samostatnému přemýšlení. Po prvotní otázce klienta pak další otázky pokládá konzultant a klient na ně hledá odpovědi. V případě, že prvotní otázka není jasně formulována, je věnován čas k upřesnění formulace. Klienti se také mohou vyhýbat formulaci otázky a namísto toho vysvětlují, co chtějí konzultovat. Může se stát, že klient položí otázku nevhodnou pro filosofickou konzultaci. Nevhodná je otázka, která není filosofická nebo na niž je zřejmá odpověd'. S takovými otázkami se ve filosofické konzultaci pracuje tak, že místo hledání odpovědi na takovou otázku bude konzultant hledat motivaci pro její položení. Na základě toho lze formulovat otázku novou, která explicitně zachytí filosofický obsah a která se stane hlavním tématem konzultace. ${ }^{50}$

Proces hledání motivace je nosným pilířem filosofické konzultace. Motivace pro dané téma se často řeší na začátku, když se konzultant zeptá, proč se klient na takovou věc dotazuje, nebo když konzultant klienta nechá vymyslet předpoklady ke kladení takové otázky. O. Brenifier svá sezení s klienty začíná otázkou „Proč jsi tady?“, která má klienta přivést k reflexi a sebe-vyjádření, je to také zástupná otázka pro „Jakou sis připravil otázku?" “. ${ }^{1}$ Motivace je pro konzultaci zásadní v tom smyslu, že obsah konzultace by měl být něčím, co klienta doopravdy zajímá, něco, co je mu blízké a na čem mu záleží. $V$ takovém případě má filosofickou konzultaci význam podstupovat, protože pouze tehdy může klientovi přinést něco hodnotného. Centrálním tématem a cílem filosofování je dobrý život, ${ }^{2}$ a proto by klient do konzultace měl přjít s takovou otázkou, jejíž zodpovězení přispěje k jeho dobrému životu. Pro návštěvu filosofického konzultanta se předpokládá prvotní údiv a zájem o poznání.

50 Příklad nevhodné otázky vyžadující reformulaci: „Co mám dělat se svým životem?“ (otázka spadající do oblasti koučinku a psychologie, možná reformulace: „Co má v lidském životě smysl?“) či „Proč jsou rostliny zelené?“ (otázka spadající do oblasti botaniky, možná reformulace: „Proč jsou jevy v realitě právě takové, jaké jsou?").

51 Viz Brenifier (The philosophical consultation, s. 38-39).

52 Viz Šulavíková (2011, s. 158). 
Filosofická konzultace není debatou, protože pointou konzultace není bojovat o předem rozhodnutou pravdu. Předpokladem filosofování je mít otevřenou mysl a být schopen kriticky a objektivně přemýšlet. Klient by měl být schopen poodstoupit od sebe samého a podívat se na téma z odstupu.

S jasně formulovanou otázkou klienta se může dále pracovat, nebot’se tak stane řešitelným teoretickým problémem. Teoretickým problémem rozumíme i např́klad etická dilemata a otázky jinak spadající do praktické filosofie: „Může člověk v životě lhát, aniž by to bylo morálně špatné?" Praktickým problémem by byla otázka spadající do kompetencí např́klad psychoterapeuta: „Jak se mohu zbavit nervozity při veřejném vystupování?“ Nově formulovaná otázka bude muset být filosofická, to znamená, že se bude moci řešit $\mathrm{v}$ abstraktní rovině nebo že bude řešit obecné pojmy. Tak by tomu bylo např́lklad u otázek „Je demokracie nejlepší způsob vlády?“ nebo „Jak se má občan v rámci demokracie odpovědně chovat?“. Může se stát, že klient položí otázku osobní. Veškeré individuální nebo konkrétní problémy se budou řešit vzhledem k rozsahu obecného nebo abstraktního pojmu. ${ }^{53}$ Nejprve se tedy bude v konzultaci řešit vymezení obecného nebo abstraktního pojmu a potom se lze vrátit $\mathrm{k}$ individuálnímu nebo konkrétnímu pojmu a vztáhnout je na sebe. Klientova otázka „Jsem spravedlivý člověk?“ by se řešila nejprve otázkou „Co je to spravedlnost?“ a následně by konzultant položil otázku „Jsi tedy ty spravedlivý člověk?" a nechal by klienta argumentovat ve prospěch své odpovědi. Konzultant př́padně argument problematizuje. ${ }^{54}$ Setkání s filosofickým konzultantem může proběhnout jednorázově, případně může být pravidelné. Využití konzultace se nabízí pro toho,

53 Odlišný přístup k filosofickým konzultacím má francouzský filosofický praktikant O. Brenifier a jeho škola. Konzultace je pro něho především nastavováním zrcadla klientovi, směřuje k projasňování myšlení, práci na rozvoji osobního postoje a kompetencí. Brenifierův přístup má svou povahou velmi blízko k psychologii, jelikož mu spíše než o řešení obsahu jde o práci s klientem a jeho myšlením. Pro více informací viz stránky: Institute of Philosophical Practices [Online] [cit. 23. 1. 2020]. Dostupné z: https://www.pratiques-philosophiques.com/eng. A stránky: Lecoq, J. (2019b): „The Philosophical consultation.“ In Dialogon [Online] Paris, (C) 2019 [cit. 25. 1. 2020]. Dostupné na: http://dialogon-en.ugal.com/the-philosophicalconsultation.

54 Kromě popsaného modelu filosofické konzultace existuje rovněž model, který můžeme nazvat jako společné filosofování. V něm konzultant nejen pokládá otázky, ale i prezentuje vlastní myšlenky a vhledy a s klientem filosofuje společně. Tento proces je nosný v tom, že může do konzultace vnést poměrně rychle kvalitní obsah a zefektivnit proces filosofického hledání. 
kdo má zájem důsledně uchopit pro něj důležité téma filosofickým způsobem. Konzultace není manipulativní praktikou s čistě utilitárními cíli, ale spíše otevřenou platformou pro důsledné filosofické přemýšlení.

\section{Závěr}

Filosofická praxe představuje pro současné české prostředí novou výzvu. Z pohledu akademické filosofie se jedná o výzvu systematicky uchopit danou disciplínu, teoreticky identifikovat její místo ve filosofické tradici a především vyrovnat se s nárokem na praktický význam filosofování $\mathrm{v}$ životě člověka. $Z$ pohledu psychologie a příbuzných oblastí (koučink) lze výzvu chápat ve smyslu vymezení hranic, kdy se jedná o filosofickou a kdy již o psychologickou praxi. Popisovaná disciplína se na skupinové rovině významně dotýká rovněž pedagogiky. Představuje možnost inovace $\mathrm{v}$ př́stupu $\mathrm{k}$ výuce žáků a studentů. Zatímco filosofie pro děti (P4C) je ve školním prostředí samotnými učiteli využívána, realizace filosofických workshopů je na školách teprve v začátcích.

Reflektujeme-li filosofickou praxi na území České republiky, můžeme dospět k otázkám, na které bude s ohledem na možný budoucí rozvoj dané disciplíny žádoucí hledat odpovědi racionální i empirickou cestou. Jaké jsou ontologické, gnoseologické, axiologické a etické předpoklady dané praxe? Jaký význam má filosofování s žáky a studenty pro jejich osobnostní rozvoj? Jak konkrétně lze využívat filosofickou konzultaci? S ohledem na skutečnost, že filosofická praxe není marginální, nýbrž celosvětově populární a rozvíjející se fenomén, považujeme za žádoucí, aby byla zkoumání této disciplíny věnována větší pozornost.

\section{Literatura}

Beekes, R. (2010): Etymological Dictionary of Greek. Brill, Leiden, Boston.

Blecha, I. (2015): „Patočkova péče o duši mezi Sókratem, Platónem

a Aristotelem." Filozofia 70 (6): 409-419.

Brenifier, O. „The Art of Philosophical Practice.“ In Institute de

Practiques Philosophiques [Online] [cit. 23.1. 2020]. Dostupné 
z: http://www.pratiques-philosophiques.fr/wp-content/ uploads/2015/o8/The-art-of-philosophical-practice-mise-enpage-1.pdf.

Brenifier, O. The Philosophical Consultation. Editions Alcofribas.

Dostupný také z: http://www.pratiques-philosophiques.fr/ wp-content/uploads/2020/o1/Philosophical-consultation-lastversion.pdf.

Centrum Filozofie pro děti. (2020): Filosofie pro děti. V centru pozornosti ... myšLenka. [Online]. Jihočeská univerzita $v$ Českých Budějovicích, Katedra pedagogiky TF, České Budějovice, (C) 2020 [cit. 31. 1. 2020]. Sekce: „Co je Filozofie pro děti“Dostupnéz: http://www.p4c.cz/index.php?s=o-projektu.

Hadot, P. (2012): Éloge de la philosophie antique. Éditions Allia, Paris; český překlad (D. Bartoň) Chvála antické filosofie, Rybka publishers, Praha, 2019.

Hadot, P. (1995a): Philosophy as a Way of Life. Blackwell's, Oxford.

Hadot, P. (1995b): Qu'est-ce que la philosophie antique? Gallimard; český překlad (M. Kř̌̌žová) Co je antická filosofie?, Vyšehrad, Praha, 2017.

Horák, O. (2015): Fỉlozofické poradenstvo - kritika. Univerzita Palackého, Olomouc.

Irwin, T. (2007): The Development of Ethics A Historical and Critical Study (Volume I: From Socrates to the Reformation). Oxford University Press, New York.

Lipman, M. (1993): Thinking Children and Education. Kendall Hunt Publishing Company, Iowa.

Lahav, R. (2014): „Interview with Viktoria Chernenko. Developing the Competencies of the Mind." In Welcome to the philopractice agora! The electronic meeting-place of philosophical practitioners from around the world [online] [cit. 13. 1. 2020]. Dostupné z: https://philopractice.org/web/viktoria-chernenko.

Louw, D. (2013): „Defining philosophical counselling: An Overview.“ South African Journal of Philosophy 32 (1): 60-70. 
Mareš, L. (2019): „Practical Role of Philosophy in Sport: Case of Philosophical Consultation." Physical Culture and Sport. Studies and Research (83): 16-25.

Nakonečný, M. (1995): Lexikon psychologie. Vodnář, Praha.

Nakonečný, M. (2015): Obecná psychologie. Triton, Praha.

Novák, L. \& Dvořák, P. (2007): Úvod do logiky aristotelské tradice. Jihočeská univerzita, České Budějovice.

NPCA (2014): „Practice Areas/Boundaries.“ In National Philosophical Counseling Association [Online]. (C) 2014 [cit. 31. 1. 2020]. Dostupné z: https://npcassoc.org/practice-areas-boundaries/

Pelcová, N. (2020): „Předmět: Dějiny filosofie výchovy.“ In Pedagogická fakulta, Univerzita Karlova. PROGRAM Filozofie výchovy a vzdělávání. [Online] Sylabus předmětu, Praha, PedF UK, (C) 2020 [cit. 4. 4. 2020]. Dostupné z: https://pedf.cuni.cz/ PEDF-2002.html.

Peregrin, J. (2010): „Filosofické poradenství, vzkvétající živnost.“ Filosofie dnes 2 (1): 55-57.

Platón (2005): Euthyfrón, Obrana Sókrata, Kritón. Přel. F. Novotný. OIKOYMENH, Praha.

Platón (2003): Kleitofón, Ústava, Timaios, Kritias. Přel. F. Novotný. OIKOYMENH, Praha.

Sharp, M. A. (2000): The Doll Hospital. ACER Press; český překlad (P. Bauman) Nemocnice pro panenky, TF JU, Centrum filozofie pro děti, České Budějovice, 2010.

Sharp, M. A. (2005): Jesse and Nakeesha. Les Presses de l'Université Laval, Québec; český překlad (M. Jedličková) Saša a Markétka, TF JU, Centrum filozofie pro děti, České Budějovice, 2011.

Šulavík, J. (2001): „Problém vztahu filozofie a psychoterapie.“ Filosofický časopis 49 (4): 585-601. 
Šulavíková, B. (2011): „Philosophical dialogue as a space for seeking

a good life, identity and critical thinking." Human Affairs 21 (2): 157-162.

\begin{abstract}

\section{Philosophical Practice In the Czech Republic}

The concept of philosophy has had several forms and meanings throughout the history. Besides the traditional theoretical focus, we may also encounter the approach that highlights a practical impact of philosophizing on one's life. This text introduces the concept of philosophical practice and reflects its current situation in the Czech Republic. Authors characterize philosophical practice as a discipline of philosophy and present its possible division into subsections. They also present its historical roots, which can be found in ancient Greece. Moreover, authors introduce available sources dealing with the philosophical practice and describe how this discipline is actually practiced in the Czech Republic. Detailed attention is given to three of its sections, namely philosophy for children $(\mathrm{P} 4 \mathrm{C})$, philosophical workshop, and philosophical consultation. Authors present theoretical background and also reflect their own methods in these sections. The text draws primarily from scholarly literature from abroad, particularly from the manuscripts and other sources produced by philosophical practitioners. The aim of this text is to introduce the concept of philosophical practice to the Czech reader and prepare the field for further academic discussion.
\end{abstract}

Keywords: philosophical practice, dialogue, philosophy for children, $\mathrm{P} 4 \mathrm{C}$, philosophical workshop, philosophical consultation

Mareš, L., Peltan, V. \& Havlová, E. (2020): „Filosofická praxe v České republice.“ Filosofie dnes 12 (2): 41-61. Dostupné z www.filosofiednes.ff.uhk.cz 


\title{
Politickofilosofický úklid v čase plurality a zběsilé strnulosti.
}

\section{Nad knihou Pavla Dufka, Jiřího Baroše, Sylvie Bláhové, Terezy Křepelové a Patrika Taufara Liberální demokracie $v$ době krize: Perspektiva politické filosofie ${ }^{1}$}

\author{
Jan Géryk \\ Právnická fakulta \\ Univerzita Karlova \\ Nám. Curieových 901/7, 11640 Praha 1 \\ gerykj@prf.cuni.cz
}

Autorský kolektiv z Katedry politologie brněnské Fakulty sociálních studií přichází s publikací, která má za cíl představit soudobé politickoteoretické diskuse nad základními aspekty liberální demokracie, jako jsou např́íklad většinové rozhodování, idea lidské důstojnosti nebo vztah demokracie a lidských práv. Nepodává však pouze učebnicový přehled, ale jednotlivé představené koncepce též kriticky hodnotí. Jako problematické pak příspěvky v knize vnímají přílišné množství dílčích teoretických inovací spěchajících zachránit liberální demokracii. To totiž v konečném důsledku vede $\mathrm{k}$ nesrozumitelné kakofonii, která zevnitř disciplíny politické teorie / politické filosofie vychází. Kniha se tak snaží o systematizaci současných diskusí a o pojmová vyjasnění. Jako zásadní věc pak vnímá též napětí mezi nutností přijímat legitimní a závazná kolektivní rozhodnutí a skutečností hluboké diverzity v současných společnostech. V poslední kapitole tak Pavel Dufek představuje jako vhodnou inspiraci pro další bádání teorie veřejného ospravedlnění. Tato recenze má za cíl seznámit čtenáře se základní strukturou a argumenty publikace. Pokouší se též témata probíraná $\mathrm{v}$ knize provázat $\mathrm{s}$ dalšími aspekty naší pozdně moderní / postmoderní situace, zejména se společenským zrychlením a proměnami veřejného prostoru.

Klíčová slova: politická filosofie, liberální demokracie, pluralismus, zběsilá strnulost, postmoderní situace

1 Tento článek vznikl v rámci projektu Specifického vysokoškolského výzkumu 2020-260 495. Za připomínky k textu děkuji Filipu Vostalovi a dvěma anonymním recenzentům. 


\section{Zběsilá strnulost po konci velkých vyprávění}

Skloňuje-li se v určitém období slovo „krize“ více než v obdobích předcházejících, stojí politické myšlení před úkoly vyžadujícími notnou dávku představivosti. Jaké budou dopady současných krizí (z posledního desetiletí kupříkladu ekonomické, klimatické, migrační či epidemické) na politické systémy? Bude třeba zásadně přizpůsobit institucionální uspořádání nové situaci, v niž krize vyústí? Jak je na tom politické myšlení v situaci, kdy jedna krize stř́ídá druhou a politika se tak stává krizovým managementem? Nezačíná překotnost událostí odrážet i politické myšlení tím, že před své publikum staví takové množství teorií a institucionálních inovací, že je orientace v současné politickoteoretické produkci stále obtížnější?

Chceme-li současnou politickou filosofii/teorii zařadit do širšího kontextu doby, je v souvislosti s výše položenými otázkami vhodné zaměřit se konkrétněji na problematiku časovosti a (společenského) zrychlení. Francouzský filosof a kulturní teoretik Paul Virilio ve své knize o fenoménu tzv. polární nehybnosti (polar inertia) vyzdvihuje roli technologického ovládnutí přenosu rychlostí světla pro naše soudobé vnímání času a prostoru. Díky možnosti okamžitého vizuálního přenosu můžeme $\mathrm{v}$ reálném čase sledovat dění na tisíce kilometrů vzdáleném místě (a také odtud být sledováni) či s pomocí panelů dálkového ovládání na tomto místě dokonce jednat. Panel dálkového ovládání je pro Virilia posledním vozidlem, které zásadně promění náš vztah k prostoru, jelikož ten už nebudeme muset fyzicky překonávat. Maximální rychlost přenosu nás tak vlastně ukotvuje ve stavu nehybnosti u ovládacího panelu, který nahrazuje naše dř́vější prostorové aktivity. ${ }^{2}$ Pokud jde o vnímání časovosti, již se tolik neřídíme ani archaickým pozorováním střídání dne a noci, ani sledováním mechaniky hodin. Je zde nový řád okamžité viditelnosti, ve kterém „plynoucí čas chronologie a historie je nahrazen časem konfrontovaným s absolutní rychlostí světla“. Jde o „přechod od extenzivního času dějin k intenzivnímu času okamžitosti bez dějin“. Reálný čas permanentní přítomnosti tak způsobuje, že

2 Virilio (1990, s. 26, 62). 
„tradiční trojice minulosti, přítomnosti a budoucnosti čím dál více ztrácí svoji použitelnost". ${ }^{3}$

Do oblasti sociální teorie přenáší Viriliovu metaforu polární nehybnosti Hartmut Rosa, když hovoří o zběsilé strnulosti (frenetic standstill), posthistorické diagnóze, podle níž kvap historických událostí ve svém důsledku paradoxně zapříčiňuje pocit ustrnutí vývoje idejí a sociálních struktur. Rychlost vývoje se navíc liší u jednotlivých společenských subsystémů, čímž dochází $\mathrm{k}$ jejich desynchronizaci. To v současnosti znamená, že vývoj ve vědě, technice či ekonomice se pro jiné subsystémy jako právo či politika stává př́liš překotným na to, aby na něj mohly přiměřeně reagovat. ${ }^{4}$

Historicky hrála $\mathrm{v}$ otázce synchronizace vývoje jednotlivých subsystémů důležitou roli (politická) filosofie. Ta vědecký a technologický vývoj ve věku modernity směrovala a propůjčovala mu legitimitu tím, že jej zasazovala do kontextu některého z velkých vyprávění, jakými byly např́klad dialektika Ducha či emancipace rozumného subjektu od překážek, které mu brání v tom, aby vládl sám sobě. Charakteristikou postmoderní situace, jak ji ve svém díle popisuje např́klad Jean-François Lyotard, je však nedůvěrivost $\mathrm{k}$ těmto velkým vyprávěním neboli metanarativním příběhům. ${ }^{5}$ Lyotarda $\mathrm{k}$ odmítnutí metanarativních př́běhů vede poznání řečové povahy společenské vazby, přičemž tato vazba „není vytvářena jediným vláknem“, nýbrž pletivem mnohých a různými pravidly se řídících řečových her. Žádný univerzální metajazyk neexistuje a „projekt systému-subjektu končí krachem“. ${ }^{6}$

Jelikož se Lyotardovi nezdá možným ani zaměření problému legitimizace na hledání univerzálního konsensu pomocí dialogu argumentací, jako to dělá Jürgen Habermas, je tedy nutné dospět k takové ideji a praxi spravedlnosti, která by vycházela z uznání různorodosti řečových her. Každý konsensus, ke kterému by se při uznání této různorodosti dospělo, by byl nutně lokální, „to znamená dosažený aktuálními partnery a nevylučující př́ípadné odvoláni““. To podle Lyotarda konečně „odpovídá vývoji

3 Tamtéž, s. 37, 25, 81.

4 Rosa (2005, s. 15, 18).

5 Lyotard (1979, s. 97, 139-140).

6 Tamtéž, s. 146-147. 
společenských interakcí“, kdy v politických, ale i kulturních či rodinných otázkách „dočasná úmluva fakticky nahrazuje trvalou instituci“.7

Tento přechod od trvalých institucí $\mathrm{k}$ dočasným úmluvám je však předmětem různých typů kritiky. Právěidea mnohosti bez sjednocujícího narativu nebo primát vytváření dočasných sítí, které se rozpadnou, jakmile dosáhnou svého dílč́ho cíle, vedou k představě společnosti, kde vše rychle kmitá, ale která se jako celek neposouvá, a to již jen proto, že se s představou celku odmítá pracovat. Rosa ostatně stav, kdy „nic nezůstává stejné, ale nic se také podstatně nemění, nazývá postmoderní antinomií. S množstvím nových problémů, které zrychlení v jiných společenských subsystémech přináší, se navíc politika dostává pod tlak a stíhá pouze reagovat na tyto aktuální problémy. Tím se dále posiluje pocit „konce dějin“ ve smyslu opuštění klasicky moderní představy vpřed ubíhajících dějin poháněných ideou pokroku. ${ }^{8}$ Konzervativní kritika postmoderního nahrazování tradičních institucí sítěmi, kterou představuje např́klad sociolog Anton C. Zijderveld, zase poukazuje na lidskou potřebu generace přesahujících vzorců chování, které ztělesňují právě instituce jakožto soubory tradičních způsobů jednání, myšlení a prožívání předávané vzděláváním a nápodobou. Instituce typu rodiny, náboženství, státu či univerzity tak jsou jednak shromaždištěm paměti, ale také nám napomáhají orientovat se na budoucnost, a to právě tím, že díky těmto relativně ustáleným vzorcům nemusíme plánovat naše jednání pokaždé znovu. To samozřejmě neznamená, že by se instituce nemohly v čase proměňovat. Právě naopak, jejich strnulost by znamenala jiný typ popření dějinnosti, a to absolutizaci minulosti. Instituce mohou během své dlouhé existence přesáhnout původní účel, ke kterému byly vytvořeny. Od dočasných sítí se však instituce liší tím, že jejich existence již nemusí být ospravedlněna účelově, ale právě samotným faktem jejich dlouhého trvání v podobě ustálených vzorců chování. ${ }^{9}$

7 Tamtéž, s. $175-176$.

8 Rosa (2005, s. 314, 313).

9 Zijderveld (200o, s. 21-22, 78-79, 32). 


\section{Politickofilosofický úklid}

Je možné tvrdit, že ani liberální demokracie jakožto soubor procedur, institucí, principů a hodnot není imunní vůči neschopnosti adaptovat se na měnící se podmínky. To je např́íklad podle Francise Fukuyamy zapříčiněno obecně lidskou predispozicí k dodržování pravidel. Tato predispozice lidi vede $\mathrm{k}$ trvající podpoře překonaných idejí a institucí i přesto, že změna je zjevně potřebná. Změna pak po dlouhém období institucionální strnulosti přichází o to náhleji a katastrofičtěji ${ }^{10}$ Skeptický je i Rosa při popisu zmíněné desynchronizace mezi společenskými subsystémy. Politika obecně, ta demokratická pak zvláště, přestává být motorem společenských změn, jako tomu bylo v období klasické modernity. Opětovná synchronizace by musela nastat urychlením politiky směrem $\mathrm{k}$ překotně zrychlené legislativní činnosti nebo na druhé straně silově prosazeným zpomalením ostatních subsystémů ${ }^{11}$, přičemž ani jedna varianta se nejeví jako zcela slučitelná s ideálem liberální demokracie. Z jiného pohledu by se však liberální demokracie mohla naopak jevit jako politické uspořádání, které je postmoderní situaci přizpůsobivé, nebot’ svým důrazem na pluralismus rezignuje na vytvoření silného sjednocujícího jazyka.

V předcházejícím odstavci se hovoří o „ideálu liberální demokracie“ a zároveň jsou zmíněna dvě vcelku protichůdná hodnocení schopnosti liberální demokracie obstát v postmoderních / pozdně moderních poměrech. Podobně může být liberální demokracie předmětem protichůdných hodnocení jistě i v dalších ohledech. Je to způsobeno jen odlišnými normativními pohledy kritiků, kteří se sice shodnou na tom, co liberální demokracie je, ale podle jedněch je příliš černá a podle jiných př́liš búlá? Nebo může být problém také v pojmové neujasněnosti politické filosofie ohledně základních východisek liberální demokracie, jež může být ještě posílena současnou teoretickou nadprodukcí v oboru?

Pokud čtenář považuje zejména posledně zmíněnou otázku za důležitou, bude s povděkem kvitovat, že v Sociologickém nakladatelství (SLON) vyšla kniha z dílny autorského kolektivu z Katedry politologie

10 Zantvoort (2017, s. 710-712).

11 Rosa (2005, s. 262-263). 
Fakulty sociálních studií Masarykovy univerzityv Brně nazvaná Liberální demokraciev době krize: Perspektiva politické filosofie. Propojuje v sobě totiž dvojí: 1) seznámení čtenáře se současnými politickofilosofickými debatami nad jednotlivými aspekty liberální demokracie, tedy toho typu vlády, jenž se podle mnohých etabloval jako jediný legitimní, ale u něhož zároveň vnímáme, že prochází hlubokou krizí (Dufek a Baroš, s. 14); ${ }^{12}$ 2) reflexi samotné disciplíny současné politické filosofie, v níž se setkáváme $\mathrm{s}$ mnohostí různých intelektuálních proudů a trendů. Metoda použitá $\mathrm{v}$ knize by se proto $\mathrm{s}$ trochou nadsázky dala označit jako „pojmově-teoretický úklid“. Publikace je totiž psána analytickým způsobem, kdy zkoumané přístupy $\mathrm{k}$ dílčím tématům nejsou pouze představeny a postaveny vedle sebe, ale jsou také vypíchnuty jejich slabé stránky a naznačeny možné důsledky kladení důrazu na ten či onen přístup. Přičemž vždy je cílem určité projasnění pojmů v mnohohlasé disciplíně politické filosofie / politické teorie. Ve svých závěrech se pak autoři a autorky často snaží nacházet mezi jednotlivými popisovanými přístupy styčné plochy, které by mohly sloužit jako minimální základ pro další teoretizování. Kniha tak naplňuje své cíle, které Pavel Dufek a Jiří Baroš v úvodu vymezují jako pedagogicko-přehledové, kriticky hodnotící a načrtávající vlastní pozici (s. 20).

Základnímu vymezení pojmu demokracie a otázce, co je cílem demokracie, se ve třetí kapitole věnuje Tereza Křepelová, a to srovnáním agregativních a deliberativních modelů demokracie. Zatímco agregativní pojetí vychází od jednotlivce a jeho zájmu a pokládá si otázku „jak přetavit individuální preference v kolektivní rozhodnutí“ (s. 77), v centru deliberativního modelu stojí „proces vzájemného ozřejmování vlastních pozic a názorů a racionalizace argumentů skrze veřejné diskuze“ (s. 86). Autorka nastiňuje riziko agregativního modelu, které spočívá $\mathrm{v}$ tom, že do procesu pouhé agregace preferencí jednotlivců bez jejich vzájemného odůvodnění mohou vstoupit zájmy vyplývající „Z emotivních či zmanipulovaných přesvědčení“. Ptá se tedy, zda právě deliberativní mechanismy pomohou zajistit to, že „na vstupu agregace

12 Budu-li odkazovat na recenzovanou knihu, použiji odkazy př́imo v textu, a to v závorce př́ijmení autora či autorky dané části knihy a číslo stránky. Pokud bude autor či autorka zmíněn v textu tak, že bude jasné, o čí kapitolu jde, uvedu pouze číslo stránky. Celá kniha je pak v seznamu literatury k nalezení pod Dufek, Baroš, Bláhová, Křepelová \& Taufar (2019). 
skutečně stojí individuální zájmy jednotlivce vycházející z uváženého soudu“ (s. 82). Na druhé straně připomíná, že „i v rámci deliberace hrají sebezájem a vlastní požadavky významnou roli“ (s. 86), přičemž je to právě deliberace, během níž se „názor každého na to, co je jeho zájem, teprve ustavuje“ (s. 91).13 Čtenáři tak ukazuje způsoby, jak se mohou dva představené modely demokracie vzájemně obohacovat, což je jistě vhodným výstupem teoretického úklidu.

Užitečným postupem pro ož̌ejmění pojmu liberální demokracie je také prozkoumání vztahu demokracie a lidských práv, čehož se v šesté kapitole ujal Patrik Taufar. Právě demokracie a lidská práva jsou totiž dva základní komponenty, jejichž „společným zhmotněním je liberálnědemokratický ústavní stát“, ale které rovněž bývají čas od času ledabyle zaměňovány (s. 132). ${ }^{14}$ Proto Taufar k popisu dynamiky vztahu těchto dvou komponentů využívá logický postup, jehož výsledkem je nastínění čtyř možných vztahů vzájemného posilování či oslabování demokracie a lidských práv. Zastánci posilujících přístupů zdůrazňují „zkvalitňování demokracie lidskoprávními garancemi“ a v opačném směru to, že demokratický způsob vlády poskytuje vhodnou podporu naplňování lidských práv. Pokud jde o vztah oslabování,jedná se o názor, že „extenzivní výklad lidských práv omezuje sféru demokratického politického rozhodování“ a v opačném směru poukazování na riziko krácení lidských práv většinovým rozhodnutím (s. 134). Zvláště po rozboru přístupů zdůrazňujících vzájemné oslabování můžečtenář dospět $\mathrm{k}$ přesvědčení o vhodnosti chápat pojem demokracie (bez přívlastku) spíše v procedurálním smyslu vlády lidu s tím, že substantivní charakter daného zřízení bude specifikován například přívlastkem liberální.

13 Podobný postoj $\mathrm{k}$ roli sebezájmu v deliberativní demokracii můžeme v české literatuře vidět i u Jany Vargovčíkové, podle níž „zájem není ani tak materiální realitou, kterou stačí zvednout a vhodit do veřejného prostoru, jako spíše konstrukcí závislou na tom, jak rozumíme svému místu ve společnosti“. Zájem jednotlivce či konkrétní skupiny tak navrhuje neodvozovat mechanicky od socioekonomického statusu, ale chápat jako proměňující se v procesu deliberace. Vyloučit zájem z deliberace by podle Vargovčíkové znamenalo připravit ji o politickou váhu. Viz Vargovčíková (2014, s. 109-111).

14 Jak ukazuje např́klad Kim Lane Scheppele, bylo to v transformujících se postkomunistických zemích střední Evropy po roce 1989 , kde pojem demokracie neznamenal v myslích občanů pouze proceduru účasti lidu na veřejných záležitostech. Demokracie byla pojmem, který zde měl mnohem více substantivní konotace, především právě dodržování základních práv ze strany státu. Proto bylo například v Mad’arsku devadesátých let, kterému se Scheppele věnuje detailně, možné, aby jako výsostně demokratický orgán byl vnímán nikoli parlament, ale ústavní soud. Viz Scheppele (2005, s. 37-38, 52). 
Pokud jde o nesnadnost politickofilosofického úklidu na poli liberální demokracie, poukazují Jiří Baroš a Pavel Dufek na vzájemnou provázanost základních aspektů liberální demokracie s dalšími konstitucionalistickými principy a také na jejich návaznost „na řadu kontextuálních proměnných" (s. 129). V páté kapitole se těchto problémů dotknou v souvislosti s rozborem principu dělby moci. Jako teoreticky obtížný vidí Baroš s Dufkem př́lišný důraz na tzv. umožňující logiku dělby moci. Zatímco logika omezující spočívá v tom, že se zvýšením nákladů okamžité koordinace možných politických jednání zabrání zneužití moci politickými představiteli (s. 118-119), logika umožňující vyzdvihuje to, že dělba moci může demokratický výkon moci také vylepšovat, např́klad činit efektivnějším (s. 119). To v důsledku podle Baroše a Dufka znamená, že zatímco omezující logika má poměrně nekontroverzní cíl „zabránění tyranii“, umožňující logika nás již vede „do hájemství politické filosofie“, jelikož je spjata s normativně zatíženými termíny typu „efektivita“, „sebeurčeni“, či „blahobyt“ (s. 122-123). Autoři tak dochází k závěru, že pokud budeme u dělby moci prioritně vycházet $\mathrm{z}$ umožňující logiky, může snadno dojít k „pojmovému roztahování“, tedy k „inflačnímu ,nacpávání pojmu normativními obsahy“ (s. 130).

Na rozdíl od dělby moci, u které byla př́lišná normativní zatíženost umožňující logiky spíše na překážku a pro snazší pojmový úklid byla vyzdvižena teoretická priorita omezující logiky, je v otázce skupinových rozhodovacích metod situace ještě složitější, jak naznačuje Pavel Dufek v osmé kapitole. Po poměrně důkladném rozboru většinového principu a jeho teoretických ospravedlnění Dufek nakonec navazuje na Mathiase Risseho, podle kterého v konečném důsledku nemůže „žádná ze strategií obhajoby většinového principu (...) dokázat jeho nadřazenost nad jinými metodami rozhodování“. Je tomu tak právě proto, že i když se majoritární agregativní přístup může jevit jako nejefektivnější „převod individuálních souborů ordinálních preferencí do společenského žebřričku preferencí, v širší perspektivě je nutno při výběru skupinové rozhodovací metody počítat i s dalšími kritérii, jako jsou „politická stabilita, efektivní implementace výsledků nebo jejich férovost“" (s. 191). Dufek se tak k Rissemu přidává ve volání po obecné teorii skupinových rozhodovacích metod, která bude sloužit k výběru vhodné rozhodovací 
metody pro konkrétní situaci. Klíčovou složkou takové obecné teorie pak musí být „soubor normativních politicko-filosofických úvah“ (s. 192). To Dufka přivádí k prvotní otázce, která zní, co od metod rozhodování vlastně požadujeme (s. 193), přičemž je nutné brát v úvahu jak „nutnost přijímat legitimní a závazná kolektivní rozhodnutí“, tak neshody plynoucí z diverzity soudobých společností (s. 194). Právě tento střet nutnosti přijmout legitimní a závazné rozhodnutí se skutečností zájmové, hodnotové a kulturní plurality je tématem, které se vine napříč recenzovanou publikací.

\section{Nepřekročitelná pluralita pozdně moderních společností}

Ve čtvrté kapitole Jiři Baroš vnímá současnou kritiku právního konstitucionalismu, který spočívá na principu, že zákonodárná moc je podřízena substantivním normám vyšší úrovně, zejména těm, které stanovují základní práva, přičemž tato podřízenost je garantována ústavním soudnictvím (s. 98, 105). Alternativám, jimiž jsou politický konstitucionalismus a demokratický konstitucionalismus, na právním konstitucionalismu vadí to, že se občané nemohou ke vnucenému obsahu ústavou zaručených práv nijak vyjádřit. Lidé by $\mathrm{v}$ souladu $\mathrm{s}$ těmito alternativními př́stupy „měli mít právo kdykoliv rekonstituovat sebe samé a demokracii prostřednictvím normálního běhu politiky“ (s. 106), přičemž zatímco politický konstitucionalismus je podle Baroše blízký režimu suverenity parlamentu (s. 107), radikálnějš́ demokratický konstitucionalismus klade důraz na projevení konstitutivní moci, a tedy vtaženílidu do procesu ústavních změn (s. 109). Baroš však pečlivězvažuje možné důsledky aplikace jednotlivých modelů v konkrétním politickém prostředí a dochází k závěru, že „politický konstitucionalismus se př́liš nehodí do středoevropského neideálního světa“, nebot’ substantivní cíle jako lidská práva a společné dobro ve střední Evropě nejsou dostatečně garantovány politickou kulturou, a proto jsou záruky, které poskytuje právní konstitucionalismus, stále zapotřebí (s. 115). Právní konstitucionalismus by však měl být podle Baroše umírněný, nebot' prosazování některých kontroverzních koncepcí lidských práv může nakonec nahrát populistickým kritikům konstitucionalismu (s. 115). 
Kontroverzní koncepcí lidských práv je v Barošově pojetí taková koncepce, která vychází jednostranně z určité morální či politické tradice, což ilustruje na př́kladu rozhodnutí amerického Nejvyššího soudu Planned Parenthood v. Casey z roku 1992. Toto rozhodnutí zabývající se otázkou potratů zdůrazňuje „právo lidí rozhodovat se samostatně o záležitostech týkajících se nejintimnějších osobních voleb v životě člověka“ (s. 208), což vyvolalo kritiku z řad autorů vycházejících $\mathrm{z}$ aristotelsko-tomistické tradice, která proti voluntaristickému pojetí autonomie jednotlivce staví koncepty odpovědnosti a společného dobra (s. 102). Přesvědčivá koncepce lidských práv by zvláště v soudních rozhodnutích měla podle Baroše „vzniknout jen ze vzájemného dialogu“ různých morálních a politických tradic (s. 115). Pokud tomu tak není, vede to konzervativněji založené autory „do náruče obhájců procedurálnějšího pojetí demokracie a politického konstitucionalismu“ (s. 103).

Na tuto diskusi Jiř́ Baroš navazuje i v kapitole deváté, kde se věnuje dvěma konkurenčním pojetím lidské důstojnosti, a to právě těm vycházejícím na jedné straně z liberální a na straně druhé z aristotelskotomistické tradice. Po prozkoumání různých zdrojů lidské důstojnosti, např́klad autonomie jednotlivce a jeho schopnosti racionální volby v liberální tradici (s. 205) nebo skutečnosti stvoření člověka k Božímu obrazu v teistické tradici (s. 210), se Baroš opět zabývá současnými projevy střetu konkurenčních pojetí lidské důstojnosti v tzv. kulturních válkách. Zásadní neshoda ohledně implikací různých pojetí lidské důstojnosti pro řešení morálních a právních sporů vede podle Baroše „některé zástupce soupeřících tradic k silným a kompromisu bránícím závěrům“. Př́kladem je Barošovi anglikánský teolog John Milbank volající po nahrazení diskurzu práv právě důstojností spjatou s dalšími pojmy jako společné dobro či solidarita (s. 214). Možným východiskem z těchto obtížných normativních debat je tak Barošovi nakonec pohlédnutí na praxi a historickou zkušenost, které nám ukazují existenci minimální shody alespoň na tom, co představuje zásadní narušení lidské důstojnosti (mimosoudní popravy, mučení, systematická diskriminace apod.) (s. 215).

Na kapitolách Jiř́iho Baroše lze dobře vidět jeden ze základních motivi̊, který prostupuje celou knihou, a tím je nutnost opatrného 
přístupu při formulaci základních pilířu liberální demokracie. Opatrnost zde znamená povědomí o důležitosti „vypořádání se s faktem hluboké diverzity v liberálních demokraciích pozdní modernity“, jak uvádí v závěrečné kapitole Pavel Dufek (s. 233). U Barošových příspěvků tak lze jako přínosné vidět nastínění perspektivy aristotelsko-tomistické tradice, která v českém intelektuálním prostředí není př́liš výrazná, nicméně její opomenutí by mohlo „mít za následek, že se část občanů bude v liberálních demokraciích cítit stále méně doma“ (s. 197).

Na místě je však otázka, kterou si v desáté kapitole klade Sylvie Bláhová, a to, zdali by se liberální teorie měla pokoušet být všezahrnujícím domovem pro všechny i za cenu rozvolnění vlastních principů. Podle autorky totiž liberální teorii využívají i ti, kdo její principy popírají, např́klad ti, kdo ve jménu liberálních principů požadují povolení obřízky u malých dívek (s. 230). Rozličným identitárním požadavkům liberalismus nemůže čelit pouze ústupky, tvrdí Bláhová a navrhuje, aby s konceptem identity, kterého se jinak ujaly multikulturalismus a populismus, začal sám liberalismus aktivně pracovat a přešel do „umírněného protiútoku“ (s. 230, 232). I Bláhová však uznává nutnost přizpůsobení se skutečnosti společenské a normativní diverzity. To řeší tím, že odlišuje sféru sociálna a sféru politična. Zatímco sféra sociálna by neměla tvořit jádro liberálního pojetí identity a měla by být „ponechána diverzitě různých morálních doktrín“, ve sféře politična už by měl liberalismus „prosazovat vlastní normativní principy tvořící jádro liberální teorie“ (s. 224, 227). Liberalismus má podle Bláhové tu výhodu, že je jediným systémem schopným „naplnit své principy výhradně v oblasti politična“ (s. 228). V této oblasti by však neměl zůstat neutrálním, přičemž autorka zde zmiňuje například Jonathana Quonga, jenž tvrdí, že „liberalismus nemusí usilovat o ospravedlnění těm, kdo již na samém počátku neakceptují základní liberální ideje“ (s. 227).

Pokud by však liberální demokracie přestala usilovat o všeobecné ospravedlnění, a přesto by u osob, které základní liberální ideje neakceptují, vynucovala dodržování zákonů, nestala by se tak nelegitimní? To je otázka, kterou v českém prostředí nedávno rozpracoval Matěj Gregárek, vycházející ovšem z anglosaské tradice filosofického anarchismu, pro který „i nelegitimní stát je možné dále ospravedlnit (avšak už bez bez- 
podmínečné obligace na straně občanů)“. ${ }^{15}$ Otázku legitimity bere jako zásadní v závěrečné kapitole recenzované publikace také Pavel Dufek, když se snaží přijít na to, ,jak je možno zdůvodnit legitimitu politické moci v situaci hluboké normativní diverzity při zachování respektu ke všem“ (s. 235), a to „aniž bychom se vraceli k chiméře sdílených důvodů či bychom přijali stanovisko filosofického anarchismu“ (s. 240). Dufek vychází z toho, že odkazy k pravdě o morálce a politice nebo idea souhlasu již jako legitimizační strategie v současné pluralitní společnosti nefungují, a uchyluje se tak k teorii veřejného ospravedlnění jakožto „úsilí o vyjasnění důvodů, které mohou být považovány za přijatelné pro všechny“ (s. 235-236). Dufkova koncepce stojí na dvou zásadách. 1) Důvody pro ospravedlnění souboru politických norem nemusí být sdílené. Každý může mít vlastní důvody pro jeho akceptaci, pokud jim druzí dokážou alespoň porozumět. 2) Aby se soubor norem stal závazným, nevyžaduje nicméně nutně souhlas všech jedinců. Není třeba, aby souhlasili ti, kdo vykazují „objektivní kognitivní nedostatečnost“, a ti, jejichž přesvědčení není „kompatibilní s ideou společenské kooperace mezi svobodnými a sobě rovnými jedinci“" (s. 242-243).

Toto široce inkluzivní pojetí veřejného ospravedlnění Dufek pojímá prozatím jako obrys výzkumného programu, což vyznívá jako př́slib dalšího rozpracování. Zve-li takto kniha do konverzace (s. 243), jedním z partnerů do dialogu by se mohla stát některá z pojetí agonistické demokracie, jež stojí na tezi, že jádrem demokratické politiky je konflikt, který, přestože není řešitelný racionálně na základě mimopolitických kritérií, může být v demokracii oživující a konstruktivní. Podle Dufka jsou agonistické prŕstupy sice spíše „prázdným příslibem“ (s. 47), nicméně stejně jako pro teorie veřejného ospravedlnění je pro ně zásadní otázkou to, jak legitimizovat jednotlivé formy regulace ve společnosti charakterizované „faktem pluralismu“, použijeme-li termín Johna Rawlse. Oba proudy vnímají to, že současný pluralismus již není jen pluralismem ve smyslu soupeření ekonomických zájmů, jak s ním pracuje agregativní pojetí demokracie. Jde především o pluralitu kulturních identit a náboženských a morálních hodnot. Jak ukazuje Mark Wenman, agonistická pojetí reakce na tuto pluralitu vycházejí z kritiky

15 Gregárek (2018, s. 17). 
Rawlse a Habermase, jejichž teorie stále pracují s určitým typem moderní racionality, která je údajně schopná přesáhnout partikulární zájmy a kulturní normy a hodnoty jednotlivých společenských skupin. Tato racionalita, jakou je u Habermase například deliberace s pomocí pravidel racionálního diskurzu, by pak měla „sloužit jako legitimní základ regulace současných forem pluralismu“. Jak rawlsovký liberalismus, tak habermasovská deliberace se však podle Wenmana zastáncům agonistických pojetí jeví jako snaha dostat společenské zápolení pod kontrolu legislativní moci rozumu. Zvláště s ohledem na kulturní a hodnotové otázky je tato snaha podle agonistických pojetí vytěsněním prvků vášní a afektů z politického prostoru. ${ }^{16}$ Agonistické varianty bychom tak mohli v souvislosti s debatou mezi realismem a idealismem v politické teorii, které se ve druhé kapitole věnuje Jiří Baroš, zařadit do realistického proudu. Charakteristiky realismu, například to, že „v jádru politiky leží neshoda“, že v politice jsou „vždy ve hře zájmy a city lidí“ a že „V ní není možný racionální konsensus“, a proto je jejím cílem spíše usměrňování konfliktu (s. 60), jsou blízké i zastáncům agonistické demokracie.

Pavel Dufek však u agonistických teorií demokracie spatřuje dva problémy. Prvním problémem je to, že i agonistické koncepce jsou nakonec vylučující, protože nejsou schopny „akomodovat ty přístupy k demokracii, které usilují právě o sémantické uzávěry, finalitu a stabilitu“. Takovým přístupem je podle Dufka i „liberalismus se svým důrazem na ústavně zakotvené limity demokratické moci“ (s. 47). Tato popisovaná neschopnost agonistické teorie demokracie vypořádat se s přístupy, které si dělají nárok na uzavření systému v určitém bodě, by však neměla být chápána tak, že by tento nárok neměl být z její strany umožněn ani jako nárok. Obecnější teorie radikální demokracie, k níž bývají agonistické varianty přriřazovány, si uvědomuje, že politika je zápasem o dosažení určité finality. Podle Ernesta Laclaua je demokratická politika sledem „konečných a partikulárních identit, které se pokoušejí ujmout univerzálních úkolơ“. V partikulárním je př́ítomná totalita, která jej neustále nutí, „aby bylo něčím více než sebou samotným“. Problémem je však to, že univerzální úkoly partikulární identitu vždy převyšují

16 Wenman (2008, s. 158-162). 
a tato vzdálenost mezi úkolem a identitou nemůže být zcela překlenuta. ${ }^{17}$ Dosažená stabilita systému, tak není univerzální a absolutní, ale pouze hegemonická. Jak uvádí Chantal Mouffe, konsensus je v liberálně demokratické společnosti vždy vyjádřením hegemonie a krystalizací mocenských vztahů, nebot’ samotná demokratická logika, která spočívá na pojmech zahrnutí a vyloučení, je překážkou realizace ideální řečové situace vedoucí k dosažení racionálního konsensu. ${ }^{18}$ Jinými slovy řečeno, radikální demokracie uznává, že partikulární identity mají univerzální a systém uzavírající nároky, ale ví, že tyto nároky nemohou být nikdy zcela realizovány. Pokud by se tak stalo, dostali bychom se již mimo oblast demokracie.

Tím se dostáváme ke druhé Dufkově poznámce stran agonistického pojetí demokracie, která říká, že i agonismus se „opírá o určitou představu normativního metakonsensu, a to $\mathrm{v}$ podobě principu (politické) rovnosti umožňující smysluplný konflikt mezi protivníky pohybujícími se ve sféře politična“. Tím pádem se podle Dufka „pod vší radikálně demokratickou rétorikou ukrývá tradiční liberální demokracie“ (s. 48). To je jistě poznámka, se kterou se lze ztotožnit, nebot například Chantal Mouffe zdo̊razňuje, že agonistický proud nesměřuje mimo liberální demokracii, pouze se ji snaží odpoutat od přílišného sepětí s osvícenským racionalismem a ekonomickým liberalismem. Snaží se tak uniknout z falešné dichotomie, kterou Mouffe ilustruje na citátu Richarda Rortyho, který ukazuje, že „můžeme vidět francouzské kritiky Habermase připravené opustit liberální politiku, aby se vyhnuli univerzalistické filosofii, a Habermase pokoušejícího se držet univerzalistické filosofie se všemi jejími problémy, aby podpořil liberální politiku“. ${ }^{19}$ Mouffe jde o to chápat agonistickou demokracii pevně v liberálnědemokratické tradici, což můžeme vidět na tom, že souhlasí s konsensem na základních hodnotách politického společenství, tedy na svobodě a rovnosti pro všechny. Těmto hodnotám však mohou být přisuzovány různé významy, mohou být jinak zaváděny do praxe. ${ }^{20} \mathrm{~A}$ přesně o to se svádí agonistický,

17 Laclau (1992, s. 47).

18 Mouffe (1999, s. 46).

19 Mouffe (2005a, s. 41).

20 Mouffe (2005b, s. 31). 
racionálně nevyřešitelný hegemonický boj. Mimo to, tedy vůči těm, kdo neuznají základní pravidla hry v politickém prostoru vymezeném hodnotami svobody a rovnosti, je již liberální demokracie nikoli ve vztahu agonistickém, nýbrž antagonistickém, nepřátelském. V rámci široké tradice liberální demokracie je však agonistické pojetí svébytné a vymezuje se proti modelům agregativní a deliberativní demokracie. ${ }^{21}$

Promýšlíme-li nastíněné vyloučení těch, kteří popírají hodnoty rovnosti a svobody pro všechny, z demokratického „my“ v pojetí Chantal Mouffe, lze si i zde položit podobnou otázku o legitimitě takového vyloučení, jakou si položil Pavel Dufek v závěrečné kapitole. V rámci agonistických variant demokracie však nepředstavuje varianta Mouffe tu jedinou. Je zde např́klad velice inkluzivní až anarchizující pojetí Williama E. Connollyho, který tematizuje pouze konstruktivní agonistické soupeření jednotlivých identit bez důrazu na vytvoření politické jednoty spojené s neustále př́ítomnou možností antagonismu, což bylo naopak důležité pro Mouffe. Jak ukazuje Wenman, Connollyvyzdvihuje pěstování ctnosti agonistického respektu, který jde za hranice pouhé tolerance a vede $\mathrm{k}$ aktivnímu střetávání různých identit a vytváření pluralismu sítí. Wenman popisuje Connollyho pojetí jako v určitých aspektech podobné agonistickému pojetí konstitucionalismu u Jamese Tullyho. Tully odmítá moderní ideu „lidu“ jako jednotné vůle a namísto toho klade důraz na neustálý mezikulturní dialog mající podobu zápasů o uznání. Rozpuštění tradičního pojetí suverenity do agonistických kulturních výměn v Tullyho přístupu tedy podle Wenmana nevyžaduje zastřešující legitimní autoritu, která by rozhodovala, kdo hraje a kdo nehraje tuto agonistickou hru..$^{22}$ Wenman však ve svém srovnání Connollyho a Tullyho pojetí odmítá z toho důvodu, že agonistický respekt a dialog vedoucí ke vzájemnému uznání sice mohou být vhodnými praktikami na úrovni podústavní politiky, avšak nemohou založit pluralistickou sociální formaci jako celek, pro což je podle Wenmana užitečnější pojetí

21 Tereza Křepelová ve třetí kapitole recenzované publikace řadí Ernesta Laclaua a Chantal Mouffe mezi radikální pluralisty v rámci deliberativní tradice (s. 85). Přesnější by však spíše bylo je z deliberativní tradice úplně vyčlenit a s radikálním pluralismem pracovat spíše v rámci samostatného modelu agonistického.

22 Wenman (2003, s. 172, 178). 
Chantal Mouffe. ${ }^{23}$ Na tomto místě však bylo důležité především ukázat, že i uvnitř proudu agonistické demokracie existuje pnutí mezi co nejširším respektem k jednotlivci či partikulární skupině a nutností v určitém bodě uzavř́t politickou komunitu. Vzhledem k tomu, že agonistické varianty jsou pak obecně citlivé k současnému „faktu pluralismu“ a pracují nejen $\mathrm{s}$ univerzální racionalitou, ale i s vášněmi a zájmy, mohou podnětně vstoupit do debaty s teoriemi veřejného ospravedlnění.

\section{Vnitrodisciplinární pluralita a (ne)směřování teorie demokracie}

Jak ukazuje Pavel Dufek v sedmékapitole, aspektem liberální demokracie, ve kterém se „ústavně-právní fikce jednoty (...) střetává se sociologickým faktem plurality“ (s. 152) snad nejvíce, je politická reprezentace. K tomu je nutno připočíst erozi tradiční reprezentativní linky volič-stranaparlament, jež je zapř́činěna nejen byrokratizací a elitizací politiky a transnacionalizací politických a hospodářských struktur a toků (s. 155), ale též samotným oslabováním reprezentativní funkce politických stran. Ty se vzdalují od společnosti a stávají se existenčně závislými jednak na veřejných financích a jednak na podnikatelsko-politických zájmech svých zakladatelů a sponzorů (s. 160-161). Nastíněná krize reprezentace pak vede politické teoretiky a teoretičky $\mathrm{k}$ mnohým dílčím inovacím v otázkách „KDO reprezentuje KOHO, jaké CHARAKTERISTIKY, jakým ZPŮSOBEM a jak došlo k VÝBĚRU“ (s. 162). Dufek mnohé z těchto inovací představuje a upozorňuje na některá jejich rizika. Kupříkladu u návrhů na posílenízvláštní reprezentacev zájmu zabránění politickému vyloučení či odstranění strukturálních nerovností se ptá, zdali „v zájmu dílčích ,zlepšovákư'“ nedochází k opuštění principu formální rovnosti, „na němž stojí demokracie jako taková a v jehož prospěch tudíž existuje „silná presumpce““ (s. 159). Obecně se pak kriticky staví proti pojmové rozplizlosti, která umožňuje „neomezené teoretické rekonfigurace“ (s. 171). Př́lišná „vnitrodisciplinární pluralita“ má v oblasti teorií politické reprezentace podle Dufka „patologické důsledky“ (s. 165).

Jedním z důležitých témat recenzované publikace je tak to, nakolik se hluboká a nepřekročitelná pluralita ve společnosti odráží také právě

23 Tamtéž, s. 170. 
ve vnitrodisciplinární pluralitě politické teorie. Pavel Dufek si v první kapitole uvědomuje, že „společenskovědní a humanitní obory nenabízí univerzální zákony, jež by bez výjimky vysvětlovaly společenské dění“, a že to $\mathrm{v}$ konečném důsledku mưže vést $\mathrm{k}$ neřešitelnému sporu „mezi hluboce zakořeněnými -ismy“ a „k ideologickému soupeření“ (s. 41-42), nicméně je kritický ke snaze přeložit tuto skutečnost do chlácholivého tvrzení, že jde o pozitivní vnitrodisciplinární pluralitu. Správně pak Dufek poukazuje na to, že chvála vnitrodisciplinární plurality nejde dohromady s tím, že „cílem normativních úvah o demokracii je prosazení vlastního pojetí demokracie a získání intelektuální hegemonie na úkor konkurenčních verzi““ (s. 31).

Václav Bělohradský používá definici ideologie od Slavoje Žižka, když tvrdí, že ideologie dnes „funguje ve fetišistickém módu jako ,ztělesněná lež‘, ke které se lidé upínají, aby překryli nějakou ,nesnesitelnou pravdu““. Tak např́lklad „fetiš transparentnosti nám umožňuje smíruit se $\mathrm{s}$,nesnesitelnou pravdou', že už dávno nemáme žádnou reálnou kompetenci k rozhodování o tom, co se nás týká“ apod. ${ }^{24} \mathrm{~V}$ návaznosti na tuto definici můžeme za fetiš označit právě i vnitrodisciplinární pluralitu, jejíž chvála nás smiřuje s tím, že politická teorie jako celek se nikam příliš neposouvá a že její „teoretická zjištění podepřená sofistikovanými argumenty (...) nenacházejí až na výjimky většího ohlasu nejen mezi širším občanstvem a odpovědnými politiky, ale ani v ostatních akademických disciplínách“ (Dufek, s. 37). To je způsobeno mimo jiné tím, že „kakofonie konfliktních hlasů vycházejících zevnitř disciplíny není pro nespecialisty srozumitelná“ (s. 37). Příznačná je v tomto směru Dufkova citace Russella Hardina, který tvrdí, že „příval domněle novátorských příspěvků má nejlepší předpoklady k tomu, aby byl ignorován nebo otevřeně zavržen“ (s. 37). Dynamika zde je, ale jde spíše o dynamiku houpacího koně, na kterém se sice můžeme houpat rychle, ale ve skutečnosti stále zůstáváme na místě. Je to dokonce nejspíše sama ona př́lišná dynamika a publikační překotnost, která setrvávání na místě zapř́ičiňuje. Vracíme se tak k úvodním poznámkám a vidíme, že i pro politickou teorii by šla použít metafora zběsilé strnulosti.

24 Bělohradský (2016). 
Tázat se pak můžeme ještě dále, jestli za utváření „do sebe uzavřených epistemických komunit“ (s. 39) nemůžeme vinit také to, že byla za špatný konec uchopena idea mezioborového př́istupu. Zmiňovaný JeanFrançois Lyotard viděl na konci sedmdesátých let dvacátého století v ideji interdisciplinarity odraz postmoderní situace. „Vnitřní eroze principu legitimity vědění (...) uvolňuje onu encyklopedickou osnovu, v níž každá věda měla najít svoje místo“, a otevírá tak „cestu k jejich emancipaci“, píše Lyotard. Doplňuje pak, že „namísto spekulativní hierarchie poznání vzniká (...) ,rovinná‘ sít výzkumných směrů, jejichž vzájemné hranice se nepřestávají přesouvat“. 25 To lze chápat jako do značné míry pozitivní závěr a lze samozřejmě uvést spoustu dobrých př́ikladů mezioborového přístupu, nicméně je třeba mít na paměti také určitá rizika. Zvláště je třeba připomenout, že není mezioborovost jako mezioborovost, což ukazuje na příkladu americké právní teorie James R. Hackney, Jr. Z rozhovorů s osobnostmi, které pokládaly základy interdisciplinárních přístupů, jakojsou law and economics nebo law and literature, se Hackney dozvídá, že zatímco v raných fázích existence těchto přístupů spočívala mezioborovost v debatách napříč akademickou sférou s dopadem i na širší veřejnost, s rostoucí specializací došlo k zapouzdření. Vznikají specificky zaměřené podobory, které sice vznikly mezioborovým kř́žením, nicméně poté již bádají na svých úzce vymezených polích. Hackney si pro popis této situace půjčuje spíše př́rodovědnou terminologii Thomase Kuhna a označuje tento stav za výsledek přechodu z období změny paradigmatu k „normální vědě“, která pouze detailně prohlubuje přístupy zakladatelů jednotlivých směrů a mimo svůj podobor již příliš nekomunikuje. ${ }^{26}$

V politické filosofii by šlo pozorovat podobný vývoj, kdy se za zcela zásadní a širokou debatu vyvolávající přelom dá považovat vydání Rawlsovy Teorie spravedlnosti v roce 1971. Toho si všímá ve druhé kapitole Jiří Baroš, když připomíná (zejména $\mathrm{v}$ angloamerickém prostředí) převahu logického pozitivismu ve filosofii a empirických behaviorálních přístupů v politické vědě v padesátých letech, což tehdy vedlo historika Petera Lasletta ke zvolání, že „politická filosofie je mrtvá“ (s. 51). Rawlsova teo-

25 Lyotard (1979, s. 145).

26 Hackney (2012, s. 16). S kuhnovskou terminologií ostatně pracuje i Dufek, když chápe společenskovědní disciplíny jako „multiparadigmatické“ (s. 40). 
rie předkládající principy fungování spravedlivé společnosti znamenala oživující impuls nejen pro liberální politické myšlení, ale také pro konkurenční proudy komunitarismu, republikanismu či radikální demokracie, které v reakci na Rawlse navíc začaly obnovovat zájem o některé ze starších klasiků politického myšlení. Kromě toho Rawlsovo dílo vyvolalo otázku o samotné úloze politické filosofie. Zde jde o Barošem popisovaný spor realismu, podle něhož politická filosofie musí uznat, že „politika se týká především jednání (...) a je vždy historicky situovaná“ (s. 64), a idealismu, který naopak tvrdí, že „lidská přirozenost nemůže a priori omezovat, co politická filosofie může předepisovat či morálně vyžadovat“ (s. 58). Vrátíme-li se však k Hackneyho schématu, po úvodních paradigmatických sporech a velkých debatách, např́iklad mezi rawlsovskými liberály a komunitaristy ohledně kulturně-historické situovanosti jedince, můžeme dnes také v politické filosofii pozorovat příklon k „normální vědě“, kdy jde spíše o detailní rozpracovávání dílčích témat $\mathrm{v}$ rámci paradigmatu.

Proto je tedy čas od času vhodné vzít do ruky přehledové publikace, jakou je právě ta recenzovaná, nebot’ ty nám poskytnou pohled takříkajíc z ptačí perspektivy na velkou část disciplinárního pole, v tomto případě na teorii demokracie. $Z$ této perspektivy pak lze v oblasti, na kterou nahlížíme, vidět pohyb jednotlivých směrů bádání a jejich vzájemnou komunikaci (či její absenci). Zde se sice jedná o práci pětičlenného autorského kolektivu, který si pole teorie demokracie rozdělil, čili nejde o komplexní vidění situace jednou osobou, nicméně jednotlivé kapitoly na sebe často odkazují a komunikují mezi sebou, takže čtenář má nakonec k dispozici poměrně komplexní a propojený obrázek. Navíc i přesto, že Pavel Dufek o autorech a autorkách knihy tvrdí, že „nejsou nutně co do svých preferencí homogenní skupinou“, čímž vysvětluje jistou zdráhavost $\mathrm{v}$ naznačení vodítek správného politického jednání (s. 233), můžemev autorském kolektivu vidět styčné plochy. Kompaktnost autorského kolektivu lze vidět především ve snaze přispět politickofilosofickým úklidem, tedy zvláště vyjasněním pojmových nejasností a poukázáním na rizika některých teoretických inovací, $\mathrm{k}$ podpoře projektu liberální či ústavní demokracie. To lze vysledovat také v tom, že populistické varianty demokracie vidí kniha jako spíše rizikové, a to 
nejen z důvodu, že populismus narušuje tradiční konstitucionalistické principy typu dělby moci (Dufek a Baroš, s. 120), ale také proto, že svým voláním po identitě celku rozporuje hlubokou společenskou diverzitu mnoha současných liberálních demokracií (Dufek, s. 156).

Zajímavé je v tomto směru srovnání recenzované publikace $\mathrm{s}$ jinou českou kolektivní monografí, která vznikla v roce 2014 a rovněž reflektovala krizi liberální demokracie, jmenovitě s knihou Demokracie $v$ postliberální konstelaci Milana Znoje, Jana Bíby a Jany Vargovčíkové. Tato kniha vychází z podobného východiska jako recenzovaná publikace, tedy z toho, že „příčiny současné krize demokracie se najdou též v povaze liberální demokracie samotné“, přičemž se rovněž nesnaží „uvažovat o neliberální demokracii či liberalismu bez demokracie“. Specifikem Demokracie $v$ postliberální konstelaci je však důraznější polemika $\mathrm{s}$ agregativním modelem demokracie, zvláště v její schumpeterovské podobě, která „demokracii redukuje na politickou soutěž elit, vůdců či stran“. Postliberální konstelace je pak „argumentační prostor“, v němž se zdůrazní „schopnosti demokracie jednat kolektivně, veřejně a politicky“, což podle Znoje, Bíby a Vargovčíkové agregativnímu modelu do znatelné míry schází. Jako možné inspirativní alternativy jsou proto představeny neorepublikanismus, deliberativní demokracie, postliberální demokracie a radikální demokracie. ${ }^{27}$ Čtenář tak jistě neprohloupí, bude-li číst Liberální demokraciiv době krize a Demokracii $v$ postliberální konstelaci pospolu, nebot jejich tematický překryv vyjma základního východiska není velký, takže dohromady poskytnou opravdu ucelený obrázek.

Liberální demokracie $v$ době krize pak navíc přináší ještě jeden zajímavý metodologický náhled, který souvisí se zmiňovanou kritikou vnitrodisciplinární plurality. Pavel Dufek naznačuje, že ve snaze vysvobodit disciplínu teorie demokracie z „labyrintu mimoběžných definic a nekompatibilních institucionálních řešení“ (s. 48) by možná bylo vhodné učinit překvapivý krok mimo samotný pojem demokracie. Stručně řečeno jde o to, že by „demokratická teorie položila své základy jinak než prostřednictvím pojmu demokracie“(s.49). Jako problematické totiž Dufek vidí to, že na pojem demokracie vytváří tlak ostatní pojmy

27 Znoj, Bíba \& Vargovčíková (2014, s. 8-9). 
politické teorie a vkládají tak do něj neudržitelné množství morálních a politických ideálo̊. Zároveň však nechce demokracii spoutat čistě proceduralistickou definicí politického režimu, kde se konají „pravidelně svobodné, rovné a všeobecné volby“ (s. 40), čímž by mohl sklouznout do schumpeterovské pasti. Poskytnutí „co možná nejkonsensuálnějšího souboru východisek pro politické teoretizování, z něhož se posléze určitá žádoucí podoba demokracie, vyloupne“"si pak slibuje od teorie veřejného ospravedlnění (Dufek a Baroš, s. 21).

Má-li se však žádoucí podoba demokracie vyloupnout právě z teorie veřejného ospravedlnění, pak by šlo pravděpodobněji o takovou podobu demokracie, jejíž instituce by byly spíše konsensuální, a proto v pluralitní společnosti štíhlé (thin). Jak ukazuje výše zmiňovaný Zijderveld, modernitu charakterizují dva procesy: jednak strukturální diferenciace, představovaná čím dál specializovanější dělbou práce a individualismem, a poté kulturní generalizace, během níž se společenské hodnoty a normy stávají abstraktnějšími a vágnějšími. V návaznosti na Maxe Webera pak ještě dodává, že hodnotová racionalita je nahrazována racionalitou účelovou či funkcionální. ${ }^{28}$ Máme-li na paměti cíl, aby se co nejvíce občanů cítilo v liberální demokracii „doma“, je v souvislosti s faktem pluralismu jistě nabízejícím se řešením př́ílon ke štíhlejším institucím a hodnotám abstraktním do té míry, že je mohou uznat jako přijatelné všichni rozumní jednotlivci. Na druhou stranu však je třeba počítat i s těmi jedinci, kteř́ jsou sice pevně ztotožněni s liberálnědemokratickými hodnotami svobody a rovnosti, avšak liberální demokracii, jejíž instituce již nejsou dostatečně robustní (thick) a naplněné konkrétnější hodnotovou racionalitou, považují za jim spíše odcizenou. Debatu o tom, jestli a nakolik by měl být pojem demokracie zatížen propojením $\mathrm{s}$ dalšími morálními a politickými ideály, tak nelze považovat za ukončenou.

Právě metafora liberální demokracie jako „domova“ může být dalším konceptem, který může vstoupit do diskuse s liberálními teoriemi veřejného ospravedlnění. Ty se totiž do té míry, do jaké odmítají pracovat $\mathrm{s}$ ideou sdílených důvodů pro ospravedlnění závazných politických rozhodnutí a pracují s důvody pouze pochopitelnými, mohou dostat $\mathrm{s}$ tradiční metaforou domova jako sdíleného prostoru do kolize. 
Antonio Rivera se při úvahách nad liberální demokracií jako domovem odkazuje na filosofku Ágnes Heller. Podle té není domovem Demokracie jako abstraktní idea, ale může jím být ta či ona konkrétní demokracie, pokud ji její občané každý den znovuzakládají, tedy pokud dále rozvíjejí demokratické dědictví, které zdědili. Na př́kladu jisté idealizované podoby americké demokracie je pak možno ukázat, že habitatem takové demokracie-domova nejsou abstraktní a univerzální principy spojené $\mathrm{s}$ velkým vyprávěním, ale právě zkušenost jejího každodenního znovuzískávání, přičemž součástí takové zkušenosti není jen souhlas a přitakání tradici, ale též disent a emancipační konflikty. ${ }^{29}$

Vyjdeme-li tedy vstříc vyloupnutí se určité podoby demokracie z teorie veřejného ospravedlnění, nabízí se otázka, zdali bude tato teorie dostatečně naplňovat onen kolektivní a veřejný aspekt demokracie, jak jej vyzdvihují např́ílad Znoj, Bíba a Vargovčíková. Jak ukazuje Rivera na obrazu moderního liberálního města, který podal začátkem dvacátého století sociolog Georg Simmel, je toto prostorem, který je tolerantní a otevřený, a právě tento liberální aspekt zabraňuje tomu, aby se metaforická demokracie-domov stala spíše vězením. Na druhé straně však namísto toho, aby bylo sdíleným útočištěm, je liberální město místem, kde se vytvář́ spíše mnohost jednotlivých uzavřených prostor. ${ }^{30}$ Tyto prostory se sice navzájem tolerují a jednotlivě uznávají přijatá rozhodnutí jakožto pochopitelná, nicméně činí tak z pohledu své vlastní partikulární identity. Pro vyvážení liberální a demokratické složky liberální demokracie se tak jako kritický diskusní partner liberálním teoriím veřejného ospravedlnění nabízí přístupy, které zdůrazňují také nutnost širokého veřejného prostoru, kam jednotlivci vstupují $\mathrm{s}$ identitou občana. Tato identita je důležitá $\mathrm{v}$ tom, že je propojena s ústavou v širším slova smyslu jakožto ohniskem politického společenství a s emancipačními boji o její změny. Jak navíc ukazuje Mouffe, politické společenství může být založeno na nikoli pouze instrumentálním, ale etickém svazku občanů, aniž by však bylo propojeno nějakou konkrétní substantivní ideou společného dobra. Co občany spojuje, je právě samotná „starost o veřejné“ a shoda na podmínkách této starosti, tedy na

29 Rivera (2018, s. 56-57).

30 Tamtéž, s. 58. 
principech svobody a rovnosti, přičemž výklad těchto principů je nicméně předmětem agonistického soupeření, čímž společenství nikdy nezískává definitivní uzavřenou podobu. ${ }^{31}$ Takto pojaté politické společenství je vhodně uzpůsobeno současnému faktu pluralismu, avšak zároveň zachovává určitou jednotu s důrazem na veřejnou identitu občana.

Jedním z alternativních pojmů, ze kterých by se mohla vyloupnout teorie demokracie, by se tak mohl stát i „veřejný prostor“ jakožto pojem, který v sobě nese př́běh společné „starosti o veřejné“. Vedle institucionálních návrhů na zabránění uzurpace moci by totiž ani liberální politická filosofie neměla rezignovat na formulování nosných společenských př́iběhů. Jak uvádí sociolog Daniel Prokop, „slabinou části současných liberálư “ je právě to, že „spoléhají na konsenzuální rétoriku a ideu společnosti, která celkovým směřováním zajištuje zlepšení života všech svých členů, ačkoli oslabili př́iběhy, o něž se tento konsenzus opíral““. ${ }^{2}$ Příběh založený na etické ideji „starosti o veřejné“ by se navíc mohl ukázat jako vhodný právě v dnešní době, kdy v různých částech světa sílí autoritářské tendence. Jak totiž víme od Hannah Arendt, „typickým znakem tyranidy není krutost, nýbrž zničení veřejné politické oblasti, kterou si tyran z ,moudrosti‘ (...) nebo z lačnosti po moci monopolizuje sám pro sebe a trvá na tom, aby se občané starali pouze o své soukromé záležitosti““. ${ }^{33}$ Nástroje politické filosofie by tak měly zdůraznit pohled do veřejného prostoru, o který ostatně přicházíme také kvưli onomu př́lišnému zrychlení, které nám dovoluje veřejným prostorem jen rychle projíždět, př́padně díky dálkovému ovládání do něj vůbec nevycházet, vrátíme-li se $\mathrm{k}$ Viriliově teorii z úvodních poznámek. Konečně z hlediska časovosti je příběh „starosti o veřejné“ něčím, co by mohlo alespoň částečně přispět $\mathrm{k}$ opětovné synchronizaci jednotlivých společenských subsystémů, a také tím, co propojuje minulost, př́tomnost a budoucnost a vymaňuje se tak z postmoderní pasti zběsilé strnulosti.

31 Mouffe (2005, s. 65-68), Wenman (2003, s. 181-182).

32 Prokop (2019, s. 140).

33 Arendt (1960, s. 288). 


\section{Literatura}

Arendt, H. (1960): Vita activa oder Vom tätigen Leben. W. Kohlhammer Verlag, Stuttgart; český překlad (V. Němec) Vita activa neboli O činném životě, OIKOYMENH, Praha, 2007.

Bělohradský, V. (2016): „Demokracie jako hrozba?“ Právo 30. 7. 2016.

Dufek, P., Baroš, J., Bláhová, S., Křepelová, T. \& Taufar, P. (2019):

Liberální demokracie v době krize: Perspektiva politické

filosofie. Sociologické nakladatelství (SLON), Praha.

Gregárek, M. (2018): Stát oběma nohama na zemi: symetrické př́stupy k legitimitě státu. Leges, Praha.

Hackney, J. R. (2012): „Introduction.“ In Legal Intellectuals in Conversation Reflections on the Construction of Contemporary American Legal Theory, J. R. Hackney, New York University Press, New York, 2012, s. 1-18.

Laclau, E. (1992): „Beyond Emancipation.“ In Emancipations, Modern and Postmodern, ed. J. N. Pieterse, Sage, London; český překlad (J. Bíba a J. Fulka) „Mimo emancipaci.“ In Emancipace a radikální demokracie, E. Laclau, Karolinum, Praha, 2013, s. 33-52.

Lyotard, J.-F. (1979): La condition postmoderne. Édition de Minuit, Paris; český překlad (J. Pejchar) „Postmoderní situace.“ In O postmodernismu : Postmoderno vysvětlované dětem : Postmoderní situace, J.-F. Lyotard, Filosofický ústav AV ČR, Praha, 1993, s. 95-202.

Mouffe, Ch. (1999): „Carl Schmitt and the Paradox of Liberal Democracy." In The Challenge of Carl Schmitt, ed. Ch. Mouffe, Verso, London, 1999, s. 38-53.

Mouffe, Ch. (2005a): The Return of the Political. Verso, London.

Mouffe, Ch. (2005b): On the Political. Routledge, London.

Prokop, D. (2019): Slepé skvrny. Host, Brno.

Rivera, A. (2018): „Are We at Home in a Liberal Democracy?

Metaphorology and Political Philosophy." In Ágnes Heller and Hannah Arendt: A Dialogue, eds. Á. Prior \& Á. Rivero, Cambridge Scholars Publishing, Newcastel upon Tyne, 2018, s. 43-59. 
Rosa, H. (2005): Beschleunigung: Die Veränderung der Zeitstrukturen in der Moderne. Suhrkamp, Frankfurt am Main; anglický překlad (J. Trejo-Mathys) Social acceleration: a new theory of modernity, Columbia University Press, New York, 2013.

Scheppele, K. L. (2005): „Democracy by Judiciary. Or, Why Courts Can be More Democratic than Parliaments." In Rethinking the Rule of Law after Communism, eds. A. Czarnota, M. Krygier \& W. Sadurski, Central European University Press, Budapest, 2005, s. $25-60$.

Vargovčíková, J. (2014): „Deliberativní demokracie: Rozpravou za hranice liberální demokracie?" In Demokracie v postliberální konstelaci, M. Znoj, J. Bíba \& J. Vargovčíková, Karolinum, Praha, 2014, s. 89-131.

Virilio, P. (1990): L'Inertie polaire. Christian Bourgois, Paris; anglický překlad (P. Camiller) Polar Inertia, Sage, London, 2000.

Wenman, M. (2003): „Agonistic Pluralism“ and Three Archetypal Forms of Politics.“ Contemporary Political Theory 2 (2): 165186.

Wenman, M. (2008): „William E. Connolly: Pluralism without Transcendence." British Journal of Politics and International Relations 10 (2): 156-170.

Zantvoort, B. (2017): „Political inertia and social acceleration.“ Philosophy and Social Criticism 43 (7): 707-723.

Zijderveld, A. C. (2000): The Intitutional Imperative: The Interface of Institutions and Networks. Amsterdam University Press, Amsterdam.

Znoj, M., Bíba, J. \& Vargovčíková, J. (2014): „Úvod.“ In Demokracie $v$ postliberální konstelaci, M. Znoj, J. Bíba \& J. Vargovčíková, Karolinum, Praha, 2014, s. 7-11. 


\section{Abstract}

Political-philosophical cleaning in times of plurality and frenetic standstill. On the book Liberal Democracy in Times of Crisis: The Perspective of Political Philosophy by Pavel Dufek, Jiří Baroš, Sylvie Bláhová, Tereza Křepelová and Patrik Taufar.

A group of authors from the Department of Political Science at the Faculty of Social Studies in Brno comes up with a publication that aims to introduce contemporary political-theoretical debates over some basic aspects of liberal democracy such as majoritarian decision-making, the idea of human dignity, or the relationship between democracy and human rights. However, the book is not a mere textbook overview, but critically evaluates the investigated conceptions. Numerous contributions in the volume perceive the excessive amount of theoretical innovations rushing to save liberal democracy as a problem. The expansion of theories leads to an incomprehensible cacophony coming from within the discipline of political theory / political philosophy. Thus, the book tries to systematize contemporary debates and to clarify basic concepts. It also addresses the tension between the necessity of taking legitimate and binding collective decisions and the fact of deep diversity in contemporary societies as a fundamental matter. In the last chapter, Pavel Dufek examines the theories of public justification as a potentially suitable inspiration for further inquiries. This review aims to familiarize the reader with the basic structure and arguments of the book. The review also tries to put the debates analyzed in the book in the context of other issues concerning our late modern / postmodern condition, especially those related to social acceleration and transformations of public space.

Key words: political philosophy, liberal democracy, pluralism, frenetic standstill, postmodern condition

Géryk, J. (2020): „Politickofilosofický úklid v čase plurality a zběsilé strnulosti. Nad knihou Pavla Dufka, Jiř́ho Baroše, Sylvie Bláhové, Terezy Křepelové a Patrika Taufara Liberální demokracie v době krize: Perspektiva politické filosofie." Filosofie dnes 12 (2): 62-87. Dostupné z www.filosofiednes.ff.uhk.cz. 


\title{
Covid-19 katastrofa: Nad knihou Richarda Hortona ${ }^{1}$
}

\author{
Daniel D. Novotný \\ Teologická fakulta \\ Jihočeská univerzita $v$ Českých Budějovicích \\ Kněžská 8, 37001 České Budějovice \\ novotnyd@jcu.cz
}

V této recenzní studii se zamýšlím nad knihou Richarda Hortona a jeho tezí, že západní země v odpovědi na současnou epidemii v první polovině roku 2020 až na výjimky selhaly. V pěti sekcích článku se po úvodní modifikaci Hortonovy teze (A) zabývám marginalizačním přístupem Číny (B), mitigačním přístupem Západu (C), epidemií SARS jako klíčové události v oblasti globálního veřejného zdraví (D), př́činami selhání Západu (epistemickými, politickými, etickými, kulturními atd.) (E), a v závěru i dalšś perspektivou (F).

Klíčová slova: etika epidemie, covid-19, veřejné zdraví, zdravotní politika, Západ

\section{A. Úvod}

Epidemie jsou jevem, který výrazně zasahuje do dějin lidstva od samých počátků. ${ }^{2}$ Je proto poměrně překvapivé, že se tomuto jevu filosofové

1 Za cenné komentáře k článku děkuji Dagmaře Dzúrové, Evě Fuchsové, Michalu Janatovi, Filipu Křepelkovi, Kamilu Sedláčkovi, Jakubovi Tomkovi a anonymním recenzentům časopisu Fillosofie dnes. Dále děkuji za podnětné diskuse k tématu článku Václavu Hořejšímu, Jaroslavu Flegrovi, Pavlu Ševčíkovi, Petru Svobodovi, Pavle Doležalové, Pavlu Vachtlovi a dalším členům Iniciativy Sníh (https://www.iniciativa-snih.cz/).

2 Termín,epidemie“ pochází etymologicky z řeckého ṡđí „na“ a $\delta \tilde{\eta} \mu$ os „lid“; pojem je definován jako nadměrný výskyt nemoci v dané populaci (bud' vǔči nulovému či nějakému základnímu, běžnému výskytu endemickému). V lékařském kontextu je termín poprvé doložen u Hippokrata v jeho díle, významově doznal v průběhu dějin proměn, srv. Martin \& Martin-Granel (2006). V tomto širším smyslu se nemusí jednat jen o epidemie infekčních, ale i neinfekčních chorob (Green et al. 2002). K dějinám epidemií, srv. Snowden (2020) a Walter-Toews (2020). Většina nových infekčních epidemií má původ ve zvířecí říši, srv. Quammen (2012). 
doposud věnovali spíše okrajově. ${ }^{3}$ Současná pandemie covid-19 nicméně podněcuje nově i zájem filosofů, především etiků, a lze očekávat, že se mu budou nadále věnovat soustavněji, než tomu bylo doposud. ${ }^{4} \mathrm{~V}$ této recenzní studii bych rád k tomuto oživenému zájmu přispěl zamyšlením nad nevelkou, nicméně pozoruhodnou knihou Richarda Hortona, šéfredaktora prestižního lékařského časopisu The Lancet, s názvem The Covid-19 Catastrophe, která byla publikována v létě 2020.5 Třebaže se jedná o knihu, kterou nenapsal profesionální filosof, obsahuje řadu podnětů, které jsou relevantní i pro filosofy, především pro ty, které zajímají etické, sociálně-politické a sociálně-epistemické souvislosti

3 Zájem je především ze strany etiků: kolektivní monografie The Ethics of Pandemics (Schwartz 2020) je patrně první knihou, která systematicky pokrývá etická témata týkající se etiky epidemií, především s ohledem na covid-19: etika veřejného zdraví, profesní zodpovědnost, spolupráce veřejnosti, alokace vzácných zdrojů, spravedlnost, etika výzkumu, soukromí a sledování, otevření společnosti. O něco méně systematický je jinak souhrnný sborník Epidemics and Ethics, vydaný po epidemii SARS, srv. Balint et al. (2006). K některým dalším etickým tématům (bezpečnost, lidská práva, demokracie atd.) se vyjadřuje i český sborník Vítězové a poražení: Právní a etické problémy současné koronakrize (Šejvl et al. 2020). Dalším významným informačním zdrojem jsou webové stránky Epidemic Ethics (https://epidemicethics.tghn.org/), které spravuje WHO ve spolupráci s dalšími organizacemi. Jedná se o platformu pro prakticky orientované bioetiky a další zájemce o multidisciplinární tematiku veřejného zdraví. Etická témata jsou ad hoc probíraná i v učebnicích epidemiologie, ovšem doposud jsem nezaregistroval, že by se tak dělo systematicky, srv. např. Rothman et al. (2008). Obsáhle se současné epidemii věnuje i speciální číslo Journal of Bioethical Inquiry (17 (4), December 2020, Symposium Title: Social and Ethical Implications of the COVID-19 Pandemic). Obecně vzato je nicméně téma infekčních chorob v bioetice relativně opomíjené. Srv. jednu z mála podrobnějších studií: The Patient as Victim and Vector: Ethics and Infectious Disease (Battin et al. 2009).

O epidemiologii a epidemie se kromě etiků zajímají i odborníci na další filosofické poddisciplíny, především epistemologové: zde se dokonce objevily pokusy o uvedení filosofie epidemie jako speciální poddisciplíny, a to v knize Philosophy of Epidemiology (Broadbent 2013). Autor se zabývá tématy, jako je kauzalita, explanace, predikce, riziko, evidence (a užití v právu), metodická pluralita, atd. Pozoruhodná diskuse k epistemologii epidemiologie se rozvinula mezi stanfordským klinickým epidemiologem Johnem Ioannidisem a harvardským infekčním epidemiologem Markem Lipsitchem a dalšími. Skvělé shrnutí diskuse poskytuje filosof medicíny z Pittsburgu Jonathan Fuller (2020). Užitečné poznámky k Ioannidisově problematickému pojetí epidemie covidu-19, srv. též Kulveit (2021). Filosofické a teologické postřehy kulturního rázu poskytují např. knihy Žižek (2020) či Lennox (2020).

4 Rostoucí bibliografii k tématu filosofie covidu-19 lze nalézt v Delvaux \& Rajan (2020).

5 Richard Horton (nar. 1961) vystudoval medicínu na Univerzitě v Birminghamu. Jako šéfredaktor časopisu The Lancet pracuje od roku 1995. Je čestným profesorem prestižních institucí jako je London School of Hygiene and Tropical Medicine, University College London, či Univerzita v Oslo. Kromě řady odborných článků přispívá i do periodik jako jsou The Times Literary Supplement a The New York Review of Books. Tématům, která jsou blízká filosofii, především etickým, sociálně epistemologickým a sociopolitickým aspektům zdravotnictví, se Horton věnuje dlouhodobě, mimo jiné i ve své knize o kontroverzích v moderní medicíně Second Opinion: Doctors, Diseases and Decisions in Modern Medicine (Horton 2003). 
krize zpo̊sobené současnou pandemií (tzv. koronakrize). Na řadě míst se autor inspiruje pracemi některých současných filosofů, naopak čistě lékařským a epidemiologickým aspektům covidu-19 se Horton téměř nevěnuje. ${ }^{6}$

Hortonova centrální teze a východisko úvah bude patrně pro některé české čtenáře provokativní7: západní svět již během prvního půl roku, tedy v době publikace knihy, selhal v odpovědi na novou epidemii, přičemž př́ičiny tohoto selhání nejsou primárně vnější, způsobené nějakou zahraniční vládou (nap̌̌. ČLR, Čínskou lidovou republikou) nebo mezinárodní institucí (např. WHO, Světovou zdravotnickou organizací), ale vnitřní. Horton svou tezi formuluje takto:
„Odpověd' vlád na covid-19 představuje největší politické selhání západních demokracií od druhé světové války. První odpovědností vlády je její povinnost pečovat o občany. Prvotní nečinnost vlád vedla k tisícům zbytečných úmrtí, kterým bylo možné se vyhnout."8

Otázky, které si Horton klade, zní, proč k tomuto došlo a jak případně podobnému selhání zabránit v budoucnosti. V této recenzní studii bych se rád spolu s Hortonem nad tezí o selhání Západu a jeho prríčinách zamyslel.

6 Z knih, které poskytují základní systematický přehled současného medicínského poznání SARSCoV-2 s odkazy na další odborné časopisecké publikace, lze doporučit Rabadán (2020). Hlubší analýzu podává sociobiolog Nicholas Christakis (2020), působící na Yaleově univerzitě. V češtině čtivým způsobem shrnul základní informace o koronaviru Koubský (2020), který se ovšem naneštěstí některým základním otázkám nevěnuje, především rozdílu mezi mitigací a marginalizací (vysvětleno dále). Dzúrová \& Jarolímek (2020) v březnu publikovali jeden z prvních kvalitních odborných článků o epidemii nového koronaviru v češtině. Pro podrobné zhodnocení z hlediska právního, srv. Křepelka (2020).

7 Např́klad pro ty, kteří nejenže nepovažují nový koronavirus za hrozbu, kterou Západ podcenil, ale naopak za falešný poplach, na který Západ reagoval přiliš razantně. Těm, kteří hrozbu nového koronaviru považují za přeceňovanou, se v Česku přezdívá „chřipečkáři“ pro jejich tendenci považovat zdravotní rizika nového koronaviru za srovnatelné s chřipkou, a tedy neopravňující k výraznějším nefarmakologickým intervencím, jako jsou plošné uzávěry či povinnost nosit roušky (srv. např. Holub 2020). Horton nijak přímo na toto stanovisko nereaguje, v zahraničí má mezi relevantními odborníky mizivou podporu, jak dokládá např. The John Snow Memorandum shrnující vědecký konsenzus (Černý et al. 2020).

8 „The response of governments to COVID-19 represents the greatest political failure of Western democracies since the Second World War. A government's first reponsibility is its duty to care to citizens. Early government inaction led to the avoidable deaths of thousands of those citizens." Horton (2020, s. 84). 
S Hortonovou tezí, v modifikované podobě uvedené níže, se ztotožňuji. Tuto studii lze tedy považovat za její zčásti samostatně postupující obhajobu. Výklad i argumentaci totiž budu strukturovat jinak než Horton, i vzhledem k tomu, že Hortonova kniha je místy nesystematická, argumentace zkratkovitá a terminologicky rozkolísaná, ke stejným otázkám se např. vyjadřuje vícekrát, dokonce i hlavní teze knihy je dle mého nejvýstižněji formulována až v páté kapitole. Poukážu dále na některé problematické aspekty Hortonovy argumentace, doplním mezery v jeho argumentaci a místy zavedu i pojmové distinkce, které Horton užívá jen implicitně. V rozsáhlém poznámkovém aparátu uvedu i odkazy na další literaturu k jednotlivým otázkám. Kategorizuji taktéž Hortonovy nesoustavné poznámky k příčinám selhání Západu, poukážu na některé meze jeho úvah týkající se tohoto tématu a identifikuji otázky, které zaslouží hlubšího zkoumání i do budoucna.

Článek je členěn takto: Nejprve, ve zbytku této úvodní sekce, bych rád pojmově precizoval Hortonovu tezi o selhání Západu, dále poukázal na metodické omezení tohoto článku, objasnil jeho motivaci a poskytl stručný informativní přehled obsahu Hortonovy knihy (A). Ve druhé části si stručně popíšeme a zhodnotíme rozdíly $\mathrm{v}$ přístupech $\mathrm{k}$ řešení epidemie v Číně (B) a následně především na Západě $(\mathrm{C})$, což poslouží jako obhajoba hlavní teze. K tématu příčin selhání Západu se váže sekce o zkušenosti s epidemií SARS (D), kterou ovšem za hlavní vysvětlení úspěchu či selhání, na rozdíl Hortona, nepovažuji. Ostatní příčiny a faktory selhání, které Horton uvádí, rozdělím na epistemické, politické a etické, a stručně je představím a navrhnu doplnění o faktory kulturní v sekci (E). Závěr je věnován výhledu na další zkoumání (F). ${ }^{9}$

Přejděme tedy nejprve k precizaci Hortonovy teze o selhání Západu. K tomuto bych rád připomenul dvojí. Zaprvé, že terminologicky budu rozlišovat mezi dvěma základními, fundamentálně odlišnými strategiemi řešení epidemie, dle cílo̊, které tato řešení sledují. Horton sám tuto terminologii neužívá, i když ji pojmově předpokládá: (1) radikální marginalizace či eliminace (supression) je strategie, jež cílí na zastavení či maximální omezení šíření viru populací; (2) mitigace (mitigation, flatten the curve) je strategie, jež cílí na pouhé zpomalení průchodu

9 V článku budu citovat z Hortonovy knihy in extenso, nebot’ v mnoha případech znějí Hortonova tvrzení týkající se veřejného zdraví a zdravotní politiky Západu poměrně radikálně a nechci je tedy opírat pouze o svou autoritu, ale o autoritu zkušeného šéfredaktora prestižního lékařského časopisu. 
infekce populací, nikoli na zastavení či minimalizaci šíření. ${ }^{10}$ Druhá strategie vede $\mathrm{k}$ výrazně vyšším ztrátám na zdraví a životech populace a nezdá se dle dostupných studií nikterak ekonomicky výhodná, ba právě naopak. ${ }^{11}$ Její zastánci např. poukazují na to, že úkolem společnosti není zachraňovat obyvatele před infekčními chorobami, ale pouze ochránit zdravotní systém před kolapsem. Jiní argumentují tím, že necháme-li projít vir populací, dosáhneme dříve přirozené skupinové imunity (herd immunity), a nebudeme se tak muset spoléhat na vakcíny a zasahovat do běžného životního stylu. S použitím této terminologie můžeme tezi článku formulovat tak, že mitigační strategie Západu selhala, zatímco eliminační strategie Číny uspěla.

Za druhé bych rád modifikoval Hortonovu tezi tím, že posunu definici „Č́ny“ a „Západu“ oproti jeho pojetí.12 Kdykoli Horton mluví o Západu, má na mysli paradigmaticky především Británii a USA, a kdykoli mluví o Číně, má na mysli především Čínskou lidovou republiku. Tento úzus může u některých povrchnějších čtenářů vyvolat klamný dojem, že selhávající přístup Západu je nějak vázán na liberálně demokratický režim, zatímco úspěšný přístup Číny na režim autoritářský. Od počátku epidemie se ovšem ukazuje, že v odpovědi na epidemii je vhodné vést řez nikoli po linii „západní liberální demokracie vs. autoritářský režim

10 Anglická i česká terminologie je rozkolísaná, především i v souvislosti s velkým multioborovým zájmem o pandemii covid-19. Pro vyjasnění terminologie běžně užívané odborníky na infekční choroby před příchodem covid-19, viz Dowdle (1998). Dle Dowdleho znamená „eliminace“ lokální snížení patogenu na nulovou či mizivou hodnotu, s rizikem importu, zatímco „eradikace“ jeho trvalé globální odstranění z populace. V tomto významu i např. Philips (2021) v diskusi o tom, zda lze covid-19 eliminovat či nikoli. Jiní autoři ovšem neváhají mluvit o „lokální eradikaci“ a „globální eradikaci“ (Wayne \& Bolker 2015, s. 21). Během pandemie byla do angličtiny zaváděna i řada nových termínů např. „flatten the curve“ („zploštit křivku“), ,zero COVID“ či „containment“ (např. Priesemann et al. 2020). Podobně i v češtině je termín „marginalizace“ nový ve významu zde užívaném, tj. minimalizace až eliminace přenosu patogenu v populaci. Přebírám jej od René Levínského a Pavla Hroboně, kteří jej zavedli na jaře 2020 (ústní komunikace).

11 Viz webové stránky Our World in Data (https://ourworldindata.org/covid-health-economy). Potvrzují se tak studie z předchozích epidemií, z nichž je patrné, že ochrana zdraví je zároveň i tou nejlepší ochranou ekonomiky. Podobné stanovisko hájí i australský ekonom Joshua Gans (2020). Pro období ekonomické výhody marginalizační strategie v období španělské chřipky srv. např. studii Correia et al (2020). Na námitku, že nelze srovnávat epidemii španělské chřipky s epidemií covid-19 a vyvozovat z tohoto srovnání nějaké závěry, lze doporučit jakýkoli úvod do studia epidemií a dalších fenoménů tzv. „závislých událostí“, např. vynikající Kucharski (2020).

12 Horton nikde nevymezuje pojem Západu, lze se ale z kontextu domnívat, že se pravděpodobně kryje s civilizačním okruhem vymezeným např. Samuelem Huntingtonem (2001), tj. USA, Kanada, tradiční katolické a protestantské části Evropy, Austrálie a Nový Zéland. Hlavní pozornost ovšem Horton věnuje Británii. Zmínka Huntingtonova dělení má v tomto článku čistě heuristický charakter a nijak nenaznačuje můj souhlas s tezemi autora. 
ČLR“, ale právě po výše zmíněné linii „mitigační přístup většiny zemí západního civilizačního okruhu“ a „eliminační přístup východních zemí čínského a budhistického civilizačního okruhu“. Důležité je tedy hned na počátku této studie zdo̊raznit fakt, že východní země zahrnují nejen autoritářské režimy jako je ČLR, ale i plné demokracie jako je Tchajwan. Navíc existují i západní země s marginalizační/eliminační strategií jako je Austrálie a Nový Zéland. ${ }^{13}$

Nyní k metodickým omezením této recenzní studie a jejich důvodům. Za prvé chronologické omezení: podobně jako Horton ve své knize publikované uprostřed léta 2020, se omezím na epidemickou situaci v první polovině roku 2020. Považuji za zásadní prokázat fakt, že Západ selhával při řešení epidemie již v tomto období první vlny, jakkoli daleko zřetelněji se v mnoha (nikoli ve všech) západních zemích projevilo selhání i v druhé polovině roku 2020, při nástupu druhé a v některých zemích dokonce i třetí vlny. ${ }^{14}$ Neschopnost dostatečně chránit veřejné zdraví v druhé polovině 2020 je přitom zřejmější, zároveň ale daleko méně pochopitelná a ospravedlnitelná, nebot’ poznání epidemie a metod jejího řešení se zásadně prohloubilo z hlediska přesnosti i míry jistoty. Toto se týká jak „známých rizik neznámého“ (dlouhodobé následky, reinfekce, mutace), tak „efektivity známého, ale jen provizorně podloženého“ např. globálními zkušenostmi a předběžnými studiemi (roušky, distancování, trasování, lockdowny a další nefarmakologické intervence). Dle Hortona i dle mého vlastního přesvědčení bylo selhávání Západu zřejmé již od počátku, prospektivně, a nikoli pouze nyní, retrospektivně. ${ }^{15}$

13 Horton sám tedy toto dělení neužívá a k zemím z ostatních civilizačních okruhů se příliš nevyjadřuje. Zdá se, že i u ostatních civilizačních okruhů by mohla existovat korelace s volbou mitigační či eliminační/marginalizační strategie: země pravoslavného, latinskoamerického a islámského civilizačního okruhu volí mitigaci, zatímco země subsaharského okruhu radikální marginalizaci. Hinduistické země (Indie, Nepál) se pokoušely od počátku spíše o marginalizaci, ovšem na rozdíl od čínských a budhistických zemí se smíšeným úspěchem. Systematické komparativní zkoumání pro jednotlivé země a kulturní okruhy by navíc muselo vzít v úvahu to, že docházelo ke změnám strategií. (Např. Česko na první vlnu reagovalo jako by cílem bylo epidemii marginalizovat, následně ovšem zvolilo mitigaci).

14 Pojem „vlna“ je vágní, v intuitivním smyslu znamená ohraničenou zvýšenou incidenci infekce či jiné relevantní veličiny, kterou lze v určitém období zřetelně sledovat, např. i vizuálně při pohledu na grafické znázornění. (Které ovšem závisí na zvoleném měřítku, navíc postupem času se např. nějaká vlna může stát téměř mizivou ve srovnání s jinou, větší, či se ukáže, že na ni lze hledět i jen jako na vlnku na jiné větší vlně).

15 Toto dokládají i mé odhady vývoje, publikované v rozhovoru v polovině března 2020 (Kerles 2020a), poukazující na dramatické rozdíly v přístupech západních a asijských zemí, a z července 2020, poukazující na vytvoření „druhé vlny“ (Kerles 2020b). 
Za druhé bych rád z hlediska metodologie poukázal na to, že při studiu našeho tématu by bylo možné postupovat nejen deskriptivně a argumentativně, ale i kvantitativně, např. analýzou statistik úmrtnosti, tj. kumulativních počtů evidovaných covid úmrtí v přepočtu na obyvatele, a to navíc i v globální komparaci pro jednotlivé země či s korelacemi na další parametry, např. ekonomické. ${ }^{16}$ Horton toto nečiní: kvantitativní údaje, které příležitostně uvádí, jsou ilustrativní a nejsou podrobeny hlubším komentářom. Podobně tedy budu postupovat i v této studii, a to především z praktických důvodů, nebot’ přínosný rozbor kvantitativních údajů byvyžadovaljinou studii sjinou metodologií.Zdejen konstatuji,žedle jakkoli zvolených kvantitativních měřítek, zásadní rozdíly v míře úspěchu mezi zeměmi marginalizačními (např. Vietnam či Thajsko) a mitigačními (např. Česko či Belgie) zůstává po celý rok 2020. V úmrtnosti dokonce bylo dosaženo až neuvěřitelných trojciferných řádových rozdílů. ${ }^{17}$

Někteří mohou Hortonovu tezi o selhání západních zemí během současné koronakrize považovat apriorně za dezinformaci. ${ }^{18}$ Důležité je proto porozumět základní Hortonově motivaci k sepsání knihy, jež spočívá $\mathrm{v}$ apelu na to, abychom se do budoucna vyhnuli zbytečným ztrátám na životech i zde na Západě a reformovali své jinak kvalitní vědecké a další liberálně demokratické instituce. Kritická sebereflexe

16 Skvělé globální statistiky poskytuje především Our World in Data (https://ourworldindata.org/ coronavirus). Agregované globální statistiky k novému koronaviru se objevily nejprve na dobrovolnickém anonymním webu Worldometer (https://www.worldometers.info/).

17 Jakkoli v tomto článku neprezentuji kvantitativní aspekty epidemie, je třeba jejich alespoň elementárního předporozumění, které lze získat studiem statistik a znalostí kontextu. Někdo by např. mohl tvrdit, že na vyhodnocení úspěšnosti nějaké strategie je př́liš brzy a že západní země, které se během první vlny „promořily“, tj. podstatná část jejich populace bud’ zemřela, či získala přirozenou imunitu, již nebudou muset čelit významné druhé vlně. A to na rozdíl od dálněvýchodních zemí, které teprve nyní zasahuje druhá vlna, která rozdíly se západními zeměmi „srovná“. Třebaže přirozená imunizace je faktorem pro rychlost šiření epidemie, ukazuje se, že ještě i na jaře 2021 (poslední revize textu tohoto článku) jsou rozdíly v druhých vlnách v západních a dálněvýchodních zemích po kvantitativní stránce dramaticky odlišné. Jinými slovy, dálněvýchodní země, které byly ochotny a schopny epidemii od počátku marginalizovat/eliminovat, měly i při druhé vlně jen mizivé počty nakažených i úmrtí, a to na rozdíl od zemí západních (např. stomiliónový Vietnam evidoval 34 úmrtí, sedmdesátimiliónové Thajsko několik osob; Tchajwan druhou vlnu neměl vůbec).

18 Např. tvrzení „EU není schopná na danou krizi efektivně reagovat“ je označeno za dezinformaci na stránkách Ministerstva vnitra ČR. (Srv: MV ČR (2021): „Koronavirus: Přehled hlavních dezinformačních sdělení. “In Ministerstvo vnitra České republiky [online]. C)2021. Dostupný z: https://www.mvcr.cz/cthh/clanek/koronavirus-prehled-hlavnich-dezinformacnich-sdeleni. aspx.) V uvedeném kontextu na stránkách ministerstva lze s tímto hodnocením patrně souhlasit, problémem se ale stává rutinní snaha označovat za dezinformaci jakoukoli kritiku poukazující na selhávání EU, Česka či jiných západních zemí a institucí. 
je prvním krokem správným směrem. Naopak popření problému či manipulace $\mathrm{s}$ fakty za tím účelem, abychom populisticky vytvořili zdání úspěchu a zakryli selhání jednotlivců i institucí, nás v budoucnu $\mathrm{s}$ vysokou pravděpodobností opět povede k obrovským zbytečným ztrátám zdravotním, hospodářským, morálním, kulturním, sportovním, vzdělanostním, a jiným. ${ }^{19}$

Hortonova kniha je rozdělena do sedmi kapitol. ${ }^{20} \mathrm{~V}$ první kapitole Horton stručně charakterizuje vlastnosti viru (index nakažlivosti, smrtnost atd.), připomíná základní chronologii událostí pro Čínu i některé západní země a podává přehled o stavu epidemie k 25. květnu (celosvětově bylo tehdy evidováno téměř 330 ooo úmrtí). V druhé kapitole se autor věnuje tématům, jako je špatná připravenost Británie na pandemii a rozhodnutí USA ukončit spolupráci s WHO, virus SARS, otázka zodpovědnosti Číny za průběh pandemie v západních zemích, a tzv. infodemie. Ve třetí kapitole Horton rozebírá úspěchy vědy během současné epidemie a paradoxně zároveň obrovské selhání vědecké politiky. Čtvrtá kapitola se krátce a nepř́liš systematicky věnuje postupu různých zemí během epidemie, zmiňuje mj. solidaritu a společnou akci jako základ služby veřejného zdravotnictví. Obzvláště zajímavá je pátá kapitola o politice covidu-19. Zde se nachází ona výše citovaná formulace Hortonovy teze, že odpověd’ západních vlád na covid-19 představuje největši selhání od druhé světové války. Selhání byla mnohá, Horton vypočítává některá $\mathrm{z}$ nich. V šesté kapitole se Horton vyjadřuje $\mathrm{k}$ roli vědy $\mathrm{v}$ (západní) společnosti, k hodnocení rizik, problému svobody a sledování, a obecně ke společenským otázkám. V závěrečné kapitole autor vypočítává změny, které současná krize dle jeho názoru přinese či by měla přinést (poukazuje např. na to, že covid-19 naneštěstí mezinárodní společenství spíše rozdělil, než spojil, očekává posílení i reformu WHO).

19 Horton dle mého zcela správně vidí v současné koronakrizi známky existenčního ohrožení západních demokracií: „... deficiencies in decision-making [that] reflect not only the surprising fragility of modern science-based societies but also something far worse - inherent failures in the mechanics of Western democracies that threaten their very existence." Horton (2020, s. 40). Důležité je zde upozornit, že se nejedná o ohrožení demokracií jako takových, nebot’ robustní asijské demokracie (Tchajwan, Korea, Japonsko, atd.) umí epidemii řešit velmi efektivně marginalizací či dokonce eliminací.

20 Pro úplnost zde uvádím názvy jednotlivých kapitol: 1 . Z Wu-chanu do světa (From Wuhan to the World), 2. Proč jsme nebyli připraveni? (Why Were We Not Prepared?), 3. Věda: paradox úspěchu a selhání (Science: The Paradox of Success and Failure), 4. První linie obrany (First Line of Defence), 5. Politika covidu-19 (The Politics of COVID-19), 6. Nové posouzení společnosti rizik (The Risk Society Revisited), 7. Na cestě k další pandemii (Towards the Next Pandemic). 


\section{B. Čína}

Původ epidemie v Číně je téma, které budí pozornost odborníků i veřejnosti. Má svůj teoretický i bezpečnostní rozměr. Poměrně záhy od vypuknutí epidemie dospěla drtivá většina odborníků $\mathrm{k}$ závěru, že původ SARS-CoV-2 lze vysvětlit zoonózou, tedy přenosem na člověka ze zviŕrete, vzhledem $\mathrm{k}$ vysoké podobnosti, kterou tento vir vykazuje s některými netopýř́mi viry. Řada odborníků dokonce již po dvě desítky let poukazovala na vysokou pravděpodobnost této události $\mathrm{v}$ daném regionu Č́ny a jihovýchodní Asie. ${ }^{21}$ Ovšem vzhledem k tomu, že z podstaty věci není snadné zjistit, kdy přesně a jak k zoonóze došlo, vzniklo záhy i podezření, zda nebyl v př́rodě vzniklý vir zkoumán či dokonce uměle modifikován $\mathrm{v}$ mezinárodní virologické laboratoři ve Wu-chanu (WIV), odkud navzdory tomu, že má nejvyšší bezpečnostní certifikaci BLS4, nějakou neštastnou náhodou unikl. ${ }^{22}$ Třebaže se nezdá být možné s absolutní jistotou vyloučit domněnky o nehodě, mezi relevantními odborníky mají mizivou podporu (jakkoli plánované a probíhající komise organizované WHO a The Lancet zkoumají i tuto možnost). Navíc, i když je otázka původu epidemie zajímavá, odpověd’ na ni není relevantní z hlediska hodnocení Hortonovy teze, je tedy pochopitelné, že se jí náš autor téměř nevěnuje. ${ }^{23}$

Další zajímavou, ovšem obtížnou a pro hlavní tezi tohoto článku nepř́lišs relevantní otázkou, je rekonstrukce rané fáze š́řrení epidemie v ČLR koncem roku 2019. I zde je třeba v mnohém čekat na další šetření a výzkum. Známe přinejmenším základní chronologický rámec pro konec prosince a pro leden: „30. prosince 2019,“ píše Horton, „byly odebrány vzorky pacientovi trpícímu na neznámý typ zápalu plic. Byl

21 Odborníci jako Peter Daszak či Shi Zhengli, kteří se mnoho let zabývají netopýŕím viromem, dlouhodobě poukazují na velkou pravděpodobnost vzniku nových infekčních nemocí typu SARS, vzhledem k obrovské virové biodiverzitě v regionu a ekologickým změnám, které doposud izolovanější živočišné druhy přivádí do blízkých kontaktů s lidmi. Srv. nap̌r. Latinne et al. (2020).

22 Srv. Cyranoski (2020). Jakkoli je známa řada nehod v biologických laboratořích po celém světě, veškeré doposud vzniklé epidemie vznikly přirozeným způsobem: apriorní pravděpodobnost vzniku další epidemie přirozeným přenosem je tedy daleko vyšší než pravděpodobnost vzniku nehodou. Je důležité nezaměňovat dvě zcela odlišné otázky totiž (a) Jaká je pravděpodobnost vzniku pandemie covid-19 únikem viru z WIV? (b) Jaká je pravděpodobnost, že ČLR potvrdí vznik pandemie covid-19 v př́padě, že skutečně vznikl únikem z WIV? Otázky biologických rizik přirozených i umělých, v kontextu obecného pojednání o existenčních rizicích, stručně pojednává Toby Ord. Srv. Ord (2020).

23 Nejnověji ke stavu mezinárodního zkoumání, srv. Mallapaty et al. (2021). 
přijat do nemocnice Jin Yin-tan ve Wu-chanu, v čínské provincii Hubei. Test reverzní transkripční polymerázové řetězové reakce (RT-PCR) potvrdil přítomnost nového typu koronaviru. “24 $\mathrm{Na}$ nebezpečí nemoci, později nazvané ,covid-19‘, kterou tento nový koronavirus způsobuje, mnozí čínští lékaři upozorňovali své kolegy i místní úřady. Zmiňován je především Li Wen-liang, oftalmolog, který na covid-19 zemřel a je dnes považován v ČLR za hrdinu, jemuž bylo na místní policejní stanici pod nátlakem uloženo, aby ohledně nové nemoci „nešířil poplašnou zprávu“. Informace od provinčních lékařuo, jako byl Li, se nicméně přesto dostaly k centrálním zdravotnickým autoritám v Pekingu. Ty kontaktovaly 31. prosince WHO, které následující den ustanovilo vyšetřující komisi. 3. ledna bylo již zaznamenáno 44 případů nové nemoci. Zdráhání ovšem nastalo s potvrzením, že dochází k přenosu z člověka na člověka (mnozí setrvávali u domněnky, že nákaza se přenáší jen z nakažených zvířat). ${ }^{25}$ Během ledna byl genotyp nového viru plně sekvenován týmem z univerzity Fu-tan v Šanghaji, v jehož čele stál Čang Jung-Čen, přičemž bylo zjištěno, že se jedná o vir př́ibuzný SARS, jednomu ze sedmi známých koronavirů, který napadá člověka. Kompletní výsledky byly zveřejněny 12. ledna. Následující den zaregistrovalo Thajsko, jako první země mimo ČLR, svůj první případ. 21. ledna první případ zachytilo USA. 23. ledna byla vyhlášena plošná karanténa ve Wu-chanu. 24. ledna začíná WHO zvažovat vyhlášení mimořádného PHEIC (Public Health Emergency of International Concern), tj. nejzávažnějšího upozornění, které WHO může vydat. ${ }^{26}$ Časopis The Lancet tohoto dne taktéž publikuje několik zásadních studií s informacemi o nové nemoci (srv. odkazy níže). Horton a mnozí další experti doporučují PHEIC vyhlásit, což se 30. ledna děje.

Po počátečním váhání došlo v ČLR někdyv druhé poloviněledna kjasné volbě radikální marginalizační/eliminační strategie. Jednalo se ovšem o mimořádně náročnou intervenci a s propuknutím nákazy zápasilo ČLR i během února. ${ }^{27} \mathrm{~K}$ čínské protiepidemické odpovědi cituje Horton zprávu WHO týmu, který ve dnech 16. až 24. února navštívil ČLR. ${ }^{28}$

\section{Horton (2020, s. 1).}

25 Podrobněji k historii prvních lednových dní, s nejnovějšími informacemi z čínských i amerických zdrojů, srv. Bucley et al. (2020). Srv. též Christakis (2020).

26 To se vydává v případě, kdy jsou splněny dvě podmínky: (1) nemoc ohrožuje veřejné zdraví tím, že se šírí na mezinárodní úrovni; (2) nemoc vyžaduje mezinárodní koordinaci při svém řešení.

27 Horton např́iklad vyzdvihuje stavbu polních nemocnic (s. 67) a odkazuje na Simiao Chen et al. (2020).

28 WHO (2020). 
„Tváří v tvář dříve neznámému viru rozvinula Čína snad historicky nejambicióznější, nejagilnější a nejagresivnější úsilí omezit šíření nemoci v historii ... Dosažení výjimečného sjednocení Číny v dodržování těchto omezujících opatření bylo možné jen díky hlubokému odhodlání obyvatel Číny ke kolektivní akci tváří v tvář tomuto společnému ohrožení ... Odvážný čínský přístup k omezení rychlého šíření tohoto nového respiračního patogenu změnil směr rychle se stupňující a smrtící epidemie. “29

Zpráva mezinárodního týmu WHO byla pozitivní. Podobně dosvědčuje mimořádně kvalitní a obětavou práci při marginalizaci viru i Horton, především co se týče spolupráce čínských odborníků, zdravotníků a obyvatelstva. ${ }^{30}$ Tyto úspěchy stojí v kontrastu s neúspěchy ČLR během epidemie SARS-CoV-2 (jak uvidíme i dále). ${ }^{31}$

Znamená to, že postup ČLR byl od samého počátku ideální, jako se jeví např. postup Tchajwanu a dalších zemí v regionu? To rozhodně nikoli. Dokonce není vyloučena ani možnost, že rychlejší a razantnější počáteční reakce úřadů ČLR mohla zcela zabránit rozšśření epidemie do světa. ${ }^{32}$ Každopádně je třeba vzít v úvahu, jak obtížné je hodnotit míru rizika na samém počátku epidemie, dokud se „nic moc“ neděje, a zvážit i cenu za falešný poplach a potenciální paniku, která hrozí. V některých zemích ještě mnoho měsíců od počátku epidemie existovali lékaři,

29 Tamtéž.

30 „Central to this success was the series of major emergency research program on virus genomics, antivirals, traditional Chinese medicines, clinical trials, vaccines, diagnostics and animal models. China's commitment to rapidly acquiring knowledge about this new virus was a critical factor in enabling the country to contain, suppress and eventually extinguish the epidemic." Horton (2020, s. 45).

31 "The contrast between this impressive response and Chinese pitiful efforts during SARS in 2002-3 illustrates the remarkable scientific renaissance that had taken place in the country in just two decades. Bin Cao's team wasn't only able to gather the state of the art data on these early patients but also encouraged to write up their work, publish it free from censorship in foreign English-language medical journals, and make their findings available to others - all within weeks of the fire reports of the new disease. The culture, as well as the scientific shift that had taken place in China was monumental." Horton (2020, s. 42-43).

32 Jedná se o otázku, kterou není snadné zodpovědět. Srv. skvělý úvod od autorky, která biomedicínskou tematiku sleduje mnoho desítek let MacKenzie (2020). Obecně skeptický přístup k možnostem včasného vyhodnocení potenciálních pandemií vyjadřuje Honigsbaum (2020), na případových studiích deseti nemocí z posledního století. 
novináři a politici, kteř́ ničivost nového viru bagatelizovali a volali po promořovacím laissez faire přístupu. Problematický postup úřadů ČLR v počátcích epidemie by tedy neměl vést ke snižování mimořádné obětavosti čínských lékařo i obyvatelstva, kterou projevili při důsledné aplikaci eliminační strategie od konce ledna:

„Čínská vláda dluží světu podrobnější vysvětlení toho, co se stalo ve Wu-chanu. ... prostě chci vědět, co se stalo. Něco se stalo. Musíme to vědět, abychom měli maximální šanci zabránit tomu, aby se to opakovalo. (...) Ale také - věřím, že to můžeme říci - si čínští vědci a zdravotníci zaslouží naši úctu. Osobně jsem poznal tyto oddané jednotlivce a vím, že neúnavně pracovali na tom, aby pochopili podstatu této pandemie. Považovali za svou povinnost informovat WHO, když si byli jisti, že je důvod signalizovat globální poplach. A při svých jednáních s čínskými vědci a veřejnými činiteli jsem nepozoroval nic jiného než mimořádné odhodlání otevřeně a bezpodmínečně spolupracovat $\mathrm{s}$ cílem porazit tuto nemoc.“ 33

Za zdůraznění zde patrně ještě jednou stojí i skutečnost, že je svým způsobem irelevantní, zda se ČLR umí s epidemií efektivně vyrovnat a poskytuje tedy pravdivé informace, či nikoli a poskytuje informace nepravdivé. Řada dalších zemí či samosprávných území v regionu, některé i s demokratickými či polodemokratickými režimy (např. Macao, Hongkong, Tchaj-wan, Jižní Korea, Thajsko, Singapur apod.), totiž epidemii bez pochybností marginalizovala či eliminovala v první polovině roku 2020 mimořádně efektivně, čímž tyto země ukázaly, že úspěšné intervence ve prospěch veřejného zdraví nejsou vázány na nějaký typ politického režimu. ${ }^{34}$

33 Horton (2020, s. 22). Zajímavá svědectví a reflexe tématu poskytuje Miller (2020), editor sborníku americko-čínské univerzitní iniciativy Duke University ve spolupráci s Wuhan University.

34 Horton sám se k postupu asijských zemí a území mimo ČLR vyjadřuje jen krátce, některé úspěšné země, jako je Vietnam či Thajsko, nezmiňuje vůbec. Jedná se o jistou slabinu Hortonovy knihy, třebaže pochopitelnou vzhledem k jejímu hlavnímu zaměření (selhání Západu, nikoli globální komparace). Spolu s Hortonem mluvím v této studii neutrálně až relativně pozitivně o Číně a opomíjím specifika Tchajwanu. Rád bych jen zdůraznil to, že epidemickou resilienci Tchajwanu považuji za naprosto exemplární, kromě její mimořádné efektivity (celková úmrt- 
Mimo ČLR bylo v době vyhlášení PHEIC koncem ledna zachyceno asi sto sedmdesát nakažených. Svět byl varován a veškeré základní informace o nové nemoci včetně nejčastějšího způsobu jejího přenosu byly známy a poskytnuty světu během ledna. Ve světle dalších šetření se může ukázat, že ČLR zdrželo informace o nové epidemii déle, než je doposud známo. Základním faktem ale zůstává, že nejpozději koncem ledna, často před vlastním zanesením infekce na své území, se mohly západní státy začít připravovat. Na rozdíl od SARS netrvalo vyhodnocení rizika osm měsíců, ale pouhý jeden. Svět byl tedy v mimořádně příznivé situaci, co se týče možnosti, jak efektivně zareagovat a epidemii zastavit jak na vlastním území, tak pomocí kooperace na mezinárodní úrovni.

\section{Západ}

Jak na PHEIC a další informace o přicházející epidemii reagoval západní svět?35 Nejprve je třeba vyzdvihnout vědeckou komunitu, která bezkonkurenčně rychle přispěla k vytvoření spolehlivého základu znalostí pro SARS-CoV-2 a nemoc covid-19. Úspěchy vědců jsou globální, mezinárodní, společné, podíleli se na něm západní i čínští vědci. Jedna z prvních odborných zpráv o nové nemoci na Západě je z 24. ledna: Bin Cao, šéf CDC z Pekingu s doktorátem ve virologii z Oxfordu, publikoval epidemiologická, klinická, laboratorní a radiologická data první skupiny pacientů v časopise The Lancet. Zde je stručný výčet dalších odborných milníků: ${ }^{6}$

nost je násobně nižší než v Číně) je třeba zdůraznit i to, že se jedná o protiepidemický úspěch demokratického režimu, patřící v r. 2020 mezi nejlépe hodnocené plné demokracie na světě. (V „Democracy Index“ časopisu The Economist obsadil Tchajwan 11. místo. Pro srovnání: Česko obsadilo až 31. místo těsně před africkými zeměmi Botswana a Cape Verde a ČLR až jedno z posledních míst, 151.), https://www.eiu.com/n/campaigns/democracy-index-2020).

35 Jak je již zmíněno v úvodu, „západním světem“ Horton myslí především Británii a USA. K ostatním západním zemím se vyjadřuje jen krátce v kapitole 4: uvádí katastrofální postup Španělska a Francie, celkem pochvalně je zmíněno Německo především díky robustnímu trasování a jasné komunikaci kancléřky Merklové (za sebe bych zde ale zdůraznil, že úspěch je to relativní s ohledem na Evropu a USA, nikoli ve srovnání s východní a jihovýchodní Asií), Švédsko označuje za „outlier“, s důrazem na individuální zodpovědnost.

36 Chaolin Huang Clinical features, The Lancet, 24. ledna 2020; Jasper Fuk-Woo Chan et al. A familia cluster of pneumonia ... The Lancet, 24. ledna 2020; Roujian Lu et al. Genomic characterization and epidemiology of 2019 novel coronavirus: implication for virus origins and receptor binding, The Lancet, 29. ledna 2020; Joseph T. Wu et al. Nowcasting and forecasting the potentia domestic and international spread of the 2019-nCov outbreak, The Lancet, 31. ledna 2020; Nanchan Chen et al. Epidemological and clinical characteristics of 99 cases ... The Lancet, 29. 
- 24. ledna: prokázán přenos z člověka na člověka (odborníci z Hongkongu a Šen-čen).

- 29. ledna: publikována genomická sekvence (tým z čínské CDC s prezidentem George Gao).

- 31. ledna: indikována vysoká pravděpodobnost globální epidemie (Gabriel Leunge spolupracující s WHO a Univerzitou v Hongkongu).

- Od konce ledna a během února: doloženo riziko mimořádné rychlosti zahlcení oddělení JIP a také velké ohrožení především starších pacientů.

Zatímco relevantní západní vědecká komunita zareagovala mimořádně rychle, nelze totéž říct o těch, kteří zodpovídají za vědeckou politiku: od konce ledna po celý únor a březen, asi sedm týdnů, vládní lékařští poradci př́chod nového viru zcela ignorovali. 3. března ministerský předseda Johnson doporučil mýt si ruce a tvrdil, že Británie je „extrémně dobře připravená“. 5. března v televizi prohlásil: „Možná bychom to mohli brát méně vážně, v celé populaci, aniž bychom zaváděli nějaká drakonická opatření.“37 Ostentativně si podával ruce se všemi, se kterými se setkal. 12. března vláda přestala trasovat. Graham Medley, jeden z vládních expertů, prohlásil, že je v pořádku nechat velké množství lidí infikovat, aby se vytvořila kolektivní imunita. ${ }^{38}$ Jedná se prý o „hezkou velkou epidemii“ (a nice big epidemic), kdy jde prý pouze o to, aby se nějak uchránila riziková část populace. Sir Patrick Vallance, hlavní poradce, mluvil dokonce na rovinu o cíli infikovat $60 \%$ britské populace. Až v průběhu března se začaly zavírat školy, bary a byl vydán př́íkaz zůstávat doma.

ledna 2020. Huijun Chen et al. Clinical characteristics and intraterine ... The Lancet, 12. února 2020. Xiabo Yang et al. Clinical course and outcomes ... The Lancet Respiratory Medicine, 21. února 2020. Srv. Také Isaac Ghinai et al. First know person-to-person ... in the USA, The Lancet, 12. března 2020.

$37, \ldots .$. Perhaps, you could sort of take it on the chin, take it all in the population without really taking as any draconian measures" Horton (2020, s. 50).

$38 \mathrm{~V}$ Česku tento přístup formulovala a pod vedením prof. Vladimíra Černého implementovala i klinická skupina Ministerstva zdravotnictví ČR. Srv. např. „Opatření vedoucí ke snižování vnímavosti populace vioči onemocnění covid-19 (tzv. přirozená imunizace)“, které stanoví, že „postupné prosazování systémových opatření navrhovaných MZ a vedoucích ke snižování vnímavosti populace vůči onemocnění COVID-19 (tzv. přirozená imunizace) považujeme za odborně správný postup a předpoklad obnovení ekonomiky a normálního života občanů." CSARIM, CSIM. (2020). 
Ještě 21. února, tj. tř̌i týdny po PHEIC, považovala klíčová vládní vědecká rada vir za středně rizikový: „Došlo ke skutečně fatální chybě v úsudku, “ píše Horton. „Vládní tvrzení, že britské zdravotnictví epidemii zvládlo úspěšně, je zavádějící už z toho důvodu, že bylo třeba odložit a radikálně omezit veškerou neakutní péči a zcela soustředit veškerou kapacitu na pacienty covid-19." "39 Nepřipravenost britského zdravotnictví je obtížně zpochybnitelný fakt, doložený již z období před pandemií. ${ }^{40}$

K USA Horton poznamenává:

„Příběh covidu-19 v USA je jedním z nejpodivnějších paradoxů celé pandemie. Žádná jiná země na světě nemá takovou koncentraci vědeckých dovedností, technických znalostí a výrobních kapacit jako USA. Je to vědecká supervelmoc světa jako žádná jiná. Tento vědecký kolos přesto nedokázal úspěšně zúročit své odborné schopnosti a přenést je do politiky ... Za tři měsíce zemřelo v USA na covid-19 více lidí než během celé války ve Vietnamu. (...) První př́ípad covidu-19 byl v USA hlášen 21. ledna ... 30. ledna hlásila americká Centra pro kontrolu a prevenci nemocí první př́ípad přenosu viru z osoby na osobu ... Vláda přesto vyhodnotila riziko pro americkou veřejnost jako ,nízkéc.“41

Je pravdou, že 31. ledna, tj. den po PHEIC, Trump sice vyhlásil „public health emergency“ a zavedl některá omezení, ale Trumpova vláda i nadále postupovala liknavě a spíše slovy než činy; již během února bylo zřejmé, že trasování a testování v USA selhalo. Zároveň se zhoršujícím se postupem epidemie v březnu a dubnu začal Trump a politici jeho typu hledat zástupné viníky: „...národní selhání byla přetavena do meziná-

39 „There was a genuinely fatal error of judgement“ (Horton 2020, s. 54). „The official government narrative was that the UK's national health service had succeeded in coping with the epidemic. Yet that assesment was only true because thousands of planned appointments and elective procedures were cancelled to create the capacity for the succeeding wave of Covid-10 admissions." (Horton 2020, s. 55).

40 Horton zmiňuje cvičení Cygnus z r. 2016, simulaci, která měla prověřit národní zdravotní systém. Výsledkem bylo 200000 mrtvých. Z těchto a podobných varovných signálů nebylo vyvozeno žádné praktické poučení.

41 Horton (2020, s. 46). 
rodních útoků." ${ }^{42}$ Proti komu se politici začali obracet ve své snaze zakrýt svá vlastní selhání? Nejčastěji proti WHO anebo ČLR. Extrémním př́kladem tohoto přístupu je zmíněný americký prezident. Jeho útok vưči WHO dokonce nabyl jakési podoby studené války, jež vedla $k$ naprostému přerušení spolupráce $\mathrm{s}$ touto nezastupitelnou mezinárodní institucí. 43 Tento krok považuje Horton za čin na úrovni „zločinu proti lidskosti“:

„Jsem přesvědčen, že rozhodnutí prezidenta Trumpa zastavit financování WHO uprostřed globální pandemie představovalo zločin proti lidskosti. Je to tvrzení přehnané? Ne, a zde je důvod. WHO existuje za účelem ochrany zdraví a dobrého života (wellbeing) národů světa. Zločin proti lidskosti je vědomý a nelidský útok proti lidem. Prezident Trump tím, že útočí na WHO a oslabuje ho, zatímco tato instituce dělá vše pro to, aby chránila národy v nejzranitelnějších zemích světa, podle mého názoru splňuje kritéria pro násilný čin, který mezinárodní společenství nazývá zločinem proti lidskosti."“4

Podobně jako americká, i britská vláda varovné signály relevantních odborníků na veřejné zdraví svévolně ignorovala. Několik měsíců po PHEIC, po hrůzném množství úmrtí a částečném kolapsu britského zdravotnictví, ministerský předseda Boris Johnson tvrdí, že „účinky [viru] jsme [v dané době] plně nechápali“. Horton neváhá použít i silná slova o tom, že mediálnímu narativu dominuje „mašinérie vládní dezinformace“ a dochází dokonce ke „kremelskému“ zatajování a cenzurování dat, např. o úmrtí. ${ }^{45}$ Skutečnost je tedy taková, že bez ohledu na to, co se stalo či děje v ČLR či WHO, došlo na straně vlád západních zemí k žalostnému selhání při ochraně veřejného zdraví: rizika nového viru byla známa, a přesto nebyly učiněny dostatečné př́ípravy

42 Tamtéž, s. 26.

43 „Globalism, international solidarity and cooperation between states were sacrificed in favour of unilateralism, nationalism and populist self-interest. It was a sad and dissappointing contrast to the unanimity among nations following the SARS outbreak in 2002-3.... The war against WHO was an unexpected twist in the story of COVID-19.“

44 Horton (2020).

45 „Kremlinesque in its audacity ... the machine of government disinformation“ Horton (2020, S. 95-96). 
na to, aby se zabránilo šíření infekce. ${ }^{46}$ Pokud se někdo retrospektivně snaží přenést odpovědnost na mezinárodní instituce či zahraniční vlády, nejedná v dobré víře.

Někdy se lze setkat $\mathrm{s}$ tvrzením, že experti měli zpočátku různé protiřečící si nepřesné modely, nejistota, jaké intervence podniknout, prý byla vysoká. Toto tvrzení nemůže dle Hortona obstát: počet ohrožených životů mohl spočítat „každý gramotný student“.47 Od ledna bylo známo, že covid-19 je smrtící nemoc. (I kdyby smrtnost byla jen dvojnásobkem sezónní chřipky, jak někteří extrémnější autoři tvrdili, jednalo by se při vyšším indexu nakažlivosti o mnohem ničivější nemoc než chřipka.) Bylo zřejmé, že se bliží nebezpečná epidemie, bylo zřejmé, že je třeba monitorovat hranice, testovat a trasovat, podporovat fyzické distancování, hygienu a další nefarmakologické postupy - a přesto se to nedělo. A když už se to začalo dít, dělalo se „příliš málo, příliš pozdě“. ${ }^{48}$ Pokušení přenášet následně zodpovědnost za vlastní selhání na WHO či ČLR je sice velké, ale jedná se o „přepisování historie“. 49

46 „Together, these failure constituted an extreme example of state negligence - a failure of governments to exercise their duty of care by ignoring evidence of possible danger, thereby exposing people to the risk of severe, sometimes fatal, harm. The evidence shows that governments could reasonably have been expected to know the risk posed by this new virus. ... It was within the power of governments to have prevented this human crisis. They failed to prevent. They omitted to save. ... Governments were causally complicit and responsible for these failures." Horton (2020, s. 86).

47 Takto: počet obyvatel krát míra promořenosti pro skupinovou imunitu krát smrtnost. Srv. další poznámku pod čarou s Hortonovým výpočtem pro Británii.“

48 „What is so mysterious is that it didn't need the predictions of scientists at Imperial College London in March to estimate impact ... Any numerate school student could make the calculation. With a mortality of 1 per cent among 60 percent of a UK population of some 66 million people, the UK could expect almost 400,00o deaths. The huge wave of critically ill patients ... would quickly overwhelm the NHS. The UK's best scientits had known since the first report from China in January that COVID-19 was a lethal illness. Yet they too did too little, too late." Horton (2020, S. 52).

49 „This message of gross incompetence is not welcome in Western political, medical or even media circles. It conflicts with a geopolitical narrative that casts China as a negative and destructive influence in international affairs. Instead, the preference has been to blame China and WHO. The claim is that China hid the fact of Covid-19. The claim is that WHO colluded with China in a cover-up of enormous proportions. ... There are many reasons to be critical of contemporary China ... [But] in the case of Covid-19, China's scientists and physicians acted decisively and responsibly to protect the health of the Chinese people ... They warned their government, their government warned WHO, and WHO warned the world. Western democracies failed to listen to those warnings. There are questions for the Chinese government and WHO to answer. But to blame China and WHO for this global pandemic is to rewrite the history of Covid-19 and to marginalize the failings of Western nations.“ (s. 87-88). ... „It is understandable that Western countries would prefer to diminish their own responsibility. Their governments are facing di- 
Západní vlády zprvu na epidemii nereagovaly, čímž již při první vlně došlo ke zbytečně velkým zdravotním i hospodářským ztrátám. Tolik Hortonovo hodnocení první části roku 2020. Došlo ke zlepšení situace v druhé části r. 2020? Zde můžeme retrospektivně říci to, co jsem zmiňoval již v úvodu, totiž že ani po bezprostředním zvládnutí první jarní vlny nedošlo ve většině západních zemí $\mathrm{k}$ rozhodnutí epidemii marginalizovat a radikálněji chránit veřejné zdraví. Až na výjimky tyto země setrvaly i nadále při strategii mitigace, tj. snahy o ochranu zdravotních systémů před kolapsem, navzdory tomu, že bylo zřejmé, že tato strategie povede v dlouhodobé perspektivě $\mathrm{k}$ mohem větším ztrátám na zdraví a životech obyvatel než strategie marginalizační. Tento fakt, myslím, jen dále posiluje tezi tohoto článku, totiž vnitřního selhávání většiny západních zemí. Zatímco v lednu 2020 byla situace pro mnohé odborníky a činitele zodpovědné za veřejné zdraví do jisté míry nejasná a jejich neznalost snad do jisté míry omluvitelná, o několik měsíců později je tato tolerance $\mathrm{k}$ počáteční neznalosti a planým spekulacím nemožná. Přesto se mnohá selhání z první poloviny roku opakovala i v polovině druhé a důvody jsou tedy hlubší než jen pomalé zpracování vědeckých poznatků či různé biasy, kterými jsou i odborníci zatíženi. ${ }^{50}$

\section{SARS}

Jaké jsou př́íčiny selhání západních zemí? Klíčové vysvětlení by mohlo dle Hortona spočívat v tom, že ČLR a další asijské země měly již zkušenost $\mathrm{s}$ vysoce smrtným SARS, kdežto západní země pouze s méně nebezpečnými epidemiemi sezónní chřipky. Než se v závěru této sekce

fficult question about what they knew and when they knew it. ... Placing responsibility for the pandemic on a country already distrusted by many citizens and an international agency that most people had barely heard of were easy diversions. It seems to work. Anti-China sentiment grew." Horton (2020, s. 89).

50 Ani selhávání při ochraně veřejného zdraví při první vlně není ovšem zcela omluvitelné v tom smyslu, „že se jednalo o legitimní pohled na věc“. Mnozí např. na jaře vydávali Švédsko s mitigační strategií za vzor s tím, že i když má třeba ve srovnání se sousedním Norskem či Finskem mnohonásobně menší úmrtnost, na podzim bude situace jistě opačná. Je tedy prý třeba „počkat do konce roku“. Nejenže se empiricky tato predikce ukázala jako mylná, nebot druhá vlna ve Švédsku menší nebyla a očekávaná, tř̌ebaže prý nezáměrná, kolektivní imunita nenastala, ale od počátku lze argumentovat proti švédskému přístupu takto: $V$ případě nejistoty, zda nějaká intervence na ochranu veřejného zdraví bude efektivní či nikoli, je morálně správné zvolit „pokus o ochranu s rizikem selhání“ před „rezignovat, protože ostatním se to možná dřive či později také nepovede“. 
vrátím k otázce, zda toto vysvětlení obstojí, připomeňme si základní data ohledně epidemie SARS a zhodnot’me si její význam.

SARS byl poprvé zachycen v listopadu 2002 jako případ „neobvyklého zápalu plic“ ve městě Fo-šan, které se nachází v provincii Kuang-tung, asi tisíc kilometrů jižně od Wu-chanu. Kvůli oslavám lunárního nového roku bylo ovšem šíření tohoto zápalu plic vesměs ignorováno. Teprve 31. ledna, kdy bylo dle údaju ČLR již infikováno 305 lidí a zaznamenáno 5 úmrtí, se zpráva o nové nemoci dostává k WHO. Další fáze nastává 21. února, kdy se na pokoji 911 hotelu Metropol v Hongkongu ubytoval infikovaný lékař z Kuang-tung. Následných 8000 doložených případů je vytrasováno právě $\mathrm{k}$ tomuto superpřenašeči z hotelu Metropol. PHEIC bylo vyhlášeno až 13. března, ovšem země světa na něj zareagovaly rychle, koordinovaně a efektivně, takže se nemoc podařilo zastavit a virus byl v květnu 2003 eradikován.

Propuknutí epidemie SARS bylo tedy poměrně krátké a omezené jen na malý počet zemí. Dopady této epidemie byly ovšem obrovské až epochální. Horton poukazuje na několik věcí, kterých si lze na událostech kolem SARS povšimnout: ${ }^{1}$

- ČLR do velké míry selhala: projevil se slabý zdravotní systém a potlačování evidence a kooperace vedlo k mezinárodní ostudě; dokonce i zdrženlivá WHO otevřeně kritizovala přístup ČLR (nový prezident Hu Jintao následně odvolal ministra zdravotnictví i pekingského starostu, došlo k masivním investicím do zdravotnictví a k rozhodnutí, že ČLR již nikdy nebude takto pokořena).

- Mezinárodní komunita si sice s novou nemocí poradila tentokrát dobře, nicméně se zřetelně potvrdilo varování, že v globalizovaném světě budou podobné epidemické události četnější a př́prava na ně by měla být jednou z národních priorit. ${ }^{2}$

- Mnohé epidemie nelze řešit jen lokálně, zásadně důležitá je kooperace a koordinovaný postup na mezinárodní úrovni.

- Nezvládnuté epidemie přinášejí obrovské ekonomické náklady; posílení připravenosti na zdravotní rizika je navíc i otázkou národní bezpečnosti.

51 Horton (2020, s. 30).

52 Knobler et al. (2004). 
- Dříve než jsou vyvinuta účinná farmakologická řešení (léky či vakcíny), což může trvat i značnou dobu, je třeba rychlých, nejlépe preventivních protiepidemických nefarmakologických intervencí: „sledování, raná detekce, izolace, trasování kontaktů, karantény, navýšení kapacity zdravotních systémů ... efektivní komunikace s veřejností."53

Horton dokonce souhlasně cituje tezi Davida Fidlera, že SARS patří mezi klíčové geopolitické události počínajícího století, protože se jedná o „první post-vestfálský patogen“:

„Od roku 1648 do roku 2002-3 bylo možné infekční nemoci - vlastně všechny nemoci - do značné míry zvládnout v rámci státních hranic. Po více než tři století byly mezinárodní vztahy utvářeny třemi principy: principem národní svrchovanosti, neintervenováním do záležitostí svrchovaných států a mezinárodním právem založeném na konsenzu ... ...pandemie vládní všemohoucnost narušila. ...SARS zahájil novou éru post-vestfálského veřejného zdraví - zdraví, které přesahuje státní hranice a národní suverenity. A sama tato éra byla slavnostně inaugurována spektakulárním úspěchem: „Globální kampaň proti SARS dosáhla vítězství, které se dostane do análů veřejného zdraví a mezinárodních vztahů." 54

Kromě SARS jsme navíc měli i následně další dvě významné epidemie nových patogenů, totiž ebolu (2013-14) a ziku (2015-16). Je tedy zřejmé, že se SARS opravdu nastává nová éra, kdy epidemie budou i nadále výrazně ovlivňovat nejen oblast globálního zdraví, ale spoluurčovat i socioekonomické a geopolitické trendy na naší planetě. 55

53 „The public health response that was needed was also clear - surveillance, early detection, isolation, contact tracing, quarantine, accumulating surge capacity within the health system ... and effective communication to the public." Horton (2020, s. 31).

54 Horton (2020, s. 32-33) a Fidler (2004). Dle mého názoru zde Horton s Fidlerem kladou globální spolupráci do př́liš silného kontrastu k národní suverenitě. Problematické je i tvrzení, že SARS je první post-vestfálský patogen; tento status by mohl připadnout i španělské chřipce.

55 Další z nových nemocí, totiž MERS se obtížně přenáší z člověka na člověka, tj. jeho nebezpečí není tak výrazné; z dřívějších nových infekčních nemocí stojí za zmínku: Hendra (1994), Nipah (1998). Odborníci již více než dvě desetiletí poukazují na rostoucí počet nových patogenů a uvádí ho do souvislosti s environmentálními změnami a zvýšenou mobilitou (Jones et al. 2008). 
Jakkoli lze souhlasit s Hortonovým hodnocením významu SARS jako takovým, otázkou je, zda zkušenost se SARS obstojí jako hlavní vysvětlení reakcí zemí na SARS-CoV-2. Celkem byl SARS zaregistrován v 29 zemích a teritoriích (počet případů 8096 a počet úmrtí 774). Patří mezi ně nejen ty, které si se současnou epidemií poradily úspěšně (ČLR, Hongkong, Tchajwan, Macao, Singapur, Vietnam, Thajsko, Mongolsko, Austrálie, Nový Zéland, atd.), ale i mnohé země, které patří mezi nejneúspěšnější (USA, Británie, Francie, Itálie, Brazílie, Švédsko, Kanada, atd.). Nezdá se tedy, že by zkušenost se SARS jako taková byla dostatečným vysvětlením, proč západní země během současné pandemie selhaly: je třeba i následného správného vyhodnocení, uchování a předávání zkušenosti s epidemiemi a budování efektivních proti-epidemických struktur na ochranu zdraví populace.

\section{E. Příčiny selhání}

Pokud nelze jednoznačně identifikovat chybějící zkušenosti se SARS jako hlavní příčinu selhání západních zemí, o jakých dalších př́ičinách lze uvažovat? Horton se k tématu vyjadřuje opakovaně, nesystematicky a na vícero místech knihy. Domnívám se, že příčiny a slabiny současného přístupu západních zemí, o nichž Horton mluví, lze rozdělit do tří skupin: epistemické, politické a morální.

Za epistemické prríčiny selhání lze považovat následující:

- ignorování nových dat a jejich pomalé hodnocení bez proaktivní snahy zjistit více; 56

- vyloučení některých relevantních disciplín a odborníků $\mathrm{z}$ diskuse; ${ }^{57}$

- neschopnost práce s nejistotou a pravděpodobností, v jejímž rámci je třeba se rozhodovat; 58

- fragmentace disciplín a odborností: „nadměrně specializo-

$56, \ldots$ UK's SAGE ... did not consider research published at the end of January which set out the magnitude of the threat ... did not reach out to those with first-hand experience of what was taking place in China." Horton (2020, s. 102).

57 „What constitutes knowledge about a risk, the assumptions we make about that risk, which evidence is ruled in and out of scope for consideration, who is invited to the table to discuss risks, and what type of science is used to shape advice to politicians." Horton (2020, s. 102).

58 Horton (2020, s. 112). 
vaná dělba práce ... zdrženlivá k praxi“;;59

- absence kritického diskurzu: umlčování kritiků vládního postupu, pokud se např. snažili poukázat na úspěšnější postupy jiných zemí; ${ }^{\circ}$

- falešný optimismus: jakkoli je i zdrojem pozitivní síly, nesmí vést $\mathrm{k}$ bagatelizaci reálných rizik. ${ }^{61}$

Epistemický problém, kterému věnuje Horton největší pozornost, je tzv. infodemie, tedy „nadmíra informací, at’ už pravdivých či nepravdivých, které zabraňují efektivní odpovědi na epidemii. Komu v této záplavě věřit?“ ${ }^{62}$ Infodemii, jejímž nejvýraznějším projevem je šíření misinformací, tj. nepravdivých informací, či dokonce dezinformací, tj. nepravdivých informací s úmyslem klamat, Horton rozděluje do čtyř oblastí: ${ }^{63}$

- pưvodu (např. nepodložená domněnka, že epidemie vznikla záměrně či zatajením nehody, jak tvrdil např. Trump, či že vznikla v souvislosti se sítěmi $5 \mathrm{G}$ );

- symptomů a přenosu (např. někteří hinduističtí nacionalis-

59 Horton zde souhlasně cituje z knihy Ulricha Becka z r. 1986 Riziková společnost, dle níž hrozbou není jen „ignorance“ ale i (nadmíra) „knowledge“: „overspecialized division of labor, their concentration on methodology and theory, their externally determined abstinence from practice - the sciences are entirely incapable of reacting adequately to civilizational risks" Beck (2004, s. 183) in Horton (2020, s. 101).

60 Horton (2020, s. 113 a 115).

$61, \ldots$ can also blind us, imbue with a sense of power and overconfidence, and mask real dangers that to be embraced, understood and addressed with humility and care. Human beings are condemned to suffer from optimism bias. We tend to overestimate the likelihood that good things will happen in life. ... An appeal for greater pessimism in our dealings with the world may not feel like an inspiring call to arms to avert the next pandemic. But if the scientists and politicians who gave advice and took decision on our behalf had adopted a little more pessimism in their predictions and policies, the deaths of hundreds of thousands of their fellow citizens around the world would have been avoided. ... We can protect and, indeed, intensify our hope through a perspective that does not mask the works that can happen to us." Horton (2020, s. 117).

62 Horton (2020, s. 38).

63 Horton (2020, s. 38-9). Vhodnější by bylo patrně rozdělení kategorie „symptomů a přenosu“ na dvě; pochybovat lze i o vhodnosti některých příkladů, které Horton uvádí. Infodemie je komplexní téma, které je třeba zkoumat i s ohledem na širší kontext: historická komparace s dezinformováním o epidemii HIV/AIDS, morální aspekty cenzury, role médií při ochraně veřejného zdraví atd. Zdroje současné infodemie jsou různorodé od státních aktérů až po dobrovolné nadšence. Významnou dezinformační roli hrají i někteří politici: „... based on a total sample of over 38 million articles published in English-language ... We found that media mentions of US President Donald Trump within the context of COVID-19 misinformation made up by far the largest share of the infodemic. Trump mentions comprised $37,9 \%$ of the overall misinformation conversation, well ahead of any other topics." (Evanega et al. 2020). 
té obvinili muslimy z korona-džihádu; xenofobii a rasismus šíril i Trump tím, že vir v kontextu rostoucího anti-asijského resentimentu nazýval v rozporu s mezinárodními pravidly „čínský vir“) 64 ;

- léčby (např. pomocí vitamínu C či koloidním stř́ibrem; dle Trumpa potenciálně vnitřním užitím dezinfekce či ozařováním);

- významu (často docházelo k bagatelizaci, např. dle Trumpa se jedná o nemoc nebezpečnou stejně jako sezónní chřipka).

Je zřejmé, že v situaci, kdy je třeba rychle a správně zhodnotit informace, na nichž závisejí zdraví a životy mnohých, je důležité postupovat zodpovědně, interdisciplinárně, konsenzuálně, ovšem zároveň velmi rychle. V mnohých zemích k podobnému postupu nedošlo, což poškodilo důvěru populace v odborníky a erodovalo možnost efektivního a rychlého protiepidemického postupu. ${ }^{65}$

Globální vědecká komunita bezkonkurenčně rychle přispěla k vytvoření spolehlivého základu znalostí o viru SARS-CoV-2 a onemocnění

64 Někdo by mohl říci, že běžně mluvíme o „španělské chřipce“ či „britské mutaci“, aniž bychom tento diskurz brali jako xenofobní. Domnívám se, že je důležité vnímat emotivní aspekt terminologie v jejím kulturním kontextu: výše uvedená označení v západních společnostech k předsudkům a násilí nepodněcují. Jinak tomu je s termínem „čínský virus“. V USA došlo během roku 2020 k prudkému nárůstu násilí proti Číňanům a obecně Asiatům, včetně vražd, při nichž hrála nepochybně motivační roli „odplata za čínský virus“. Podobně by bylo jistě nevhodné v nějaké africké či asijské společnosti označovat nějakou nemoc jako „západní“ v př́ípadě, že by mohlo docházet k nárůstu násilí proti bělochům. A naopak v rámci čínské společnosti nemusí mít např. termín „wuchanský virus“ nebezpečné negativní konotace.

65 V samotné Británii a USA poměrně záhy došlo mezi odborníky na veřejné zdraví a epidemiology ke konsenzu ohledně výhod marginalizační strategie. Naneštěstí ale v oblasti rozhodování zvítězili obhájci krátkodobých politických a ekonomických zájmů, kteří prosazovali jiná řešení navzdory předvídatelným ničivým dlouhodobým dopadům. Zbytečné a destruktivní zmatky také nastaly v prvních měsících při medializaci některých spekulativních a nepodložených názorů odborníků, srv. pronikavá analýza Yong (2020). V Česku na rozdíl od zahraničí ke konsenzu mezi odborníky nedošlo, resp. se zdá, že relevantní odborníci MZ ČR podpořili „přirozenou imunizaci“, neboli promoření (srv. poznámka 37). Hledání důvodů by patrně vyžadovalo samostatné zkoumání, zde bych rád alespoň zmínil následující vysvětlení: Integrativní, interdisciplinární obor veřejné/globální zdraví v Česku neexistuje. Za experta na epidemie se považuje jakýkoli lékař, i kdyby byla jeho vlastní specializace od tematiky epidemie a veřejného zdraví sebevzdálenější (např. stomatologie, onkologie, anesteziologie, atd.). Schopnost porozumět epidemiím přitom vykazují daleko více např. matematici, datoví vědci a ekonomové než lékaři. Lékařské vzdělání je totiž většinou zaměřeno spíše klinicky, nemoc z tohoto hlediska je sledována abstrahovaně jako nezávislý jev. Pro porozumění epidemii je přitom zásadní právě závislostní charakter přenosu nemocí, což je aspekt nemoci, pro který většina lékařů nemusí mít dostatečnou intelektuální průpravu. 
covid-19. „A přesto řešení covid-19,“ píše Horton, „představovalo v mnoha zemích největší selhání vědní politiky (science policy) této generace. Co se stalo?"66 Horton mluví o několikerých selháních současných režimů západních zemí, a zde lze mluvit o politických př́ičinách:

- zneužití moci: doložené mj. naprostou absencí proaktivního ověření si varovných signálů, které přicházely z WHO a dalších zdrojů; ${ }^{67}$

- komplicita: především při zakrývání vlastního selhání a vyvolávání klamného zdání, že země v porovnání s ostatními zeměmi zvládá epidemii dobře ${ }^{68}$

- nekomunikativnost: osvěta byla nedostatečná a opožděná. ${ }^{69}$

Obzvláště důležitým faktem, který indikuje selhání západních politiků, je jejich podíl na dezinformování a lhaní:

„Už jsem hovořil o ... infodemii ..., která se objevila během krize covid-19. Ještě překvapivější a neočekávanější bylo, že samotné vlády se uchýlily k politickým dezinformačním kampaním, aby obhájily svou vlastní roli, kterou sehrály při zvládání epidemie. Tyto snahy o přepsání příběhu covid-19je důležité zdokumentovat. Stejně jako došlo k boji o potlačení epidemie, existuje také boj o kontrolu nad veřejným pohledem na vládní zvládání epidemie. Britští politici například tvrdí, že [ani] na počátku epidemie se nepokoušeli

66 Horton (2020, s. 41).

67 „It was an abuse of power because the system of science policy formation failed to act on clear and unambiguous signals from China that culminated in a PHEIC from WHO on 30 January. When a PHEIC was called, government scientific advisory committees ... should have urgently started asking questions. They should have contacted their counterparts in China and Hong Kong - Bin Cao, George Gao, George Leung - to seek first-hand testimony about what was happening. They should have called WHO country office in Beijing to understand their assesment of the situation in Wuhan. If they had done so, our most senior scientific advisors would have heard the same messages so starkly reported in their published papers from January - a pandemic of a bitterly toxic virus on its way to Europe. The fact that they apparently took none of these actions is what constitutes the abuse of entrusted power." Horton (2020, s. 58).

$68, \ldots$ scientists and politicians agreed to act together in order to protect the government, to give the illusion that the UK was an ,international exemplar' in preparedness and made the right desicions at the right time, based upon the science." Horton (2020, s. 55).

$69, \ldots$ the messages delivered to the public were often too little, too late“ Horton (2020, s. 86). 
o politiku skupinové imunity. Prohlášení jich samých i jejich vědeckých poradců jasně dokazují opak.“70

Je zřejmé, že věda a zdravotnictví je i záležitostí politickou. ${ }^{71}$ To ovšem neznamená, že politikové mají či mohou zasahovat do procesů kritické diskuse ve vědecké komunitě jinak, než vedeni zájmem o ochranu veřejného zdraví a dalších důležitých hodnot společnosti. Je možné, že jisté aspekty „intenzivního kapitalismu“ a západních politických institucí bude třeba přehodnotit a to i po právní stránce, zdá se totiž, že sociální předivo mezi lidmi bylo narušeno a lidé jsou bráni jako pouhý nástroj. ${ }^{72}$

V souvislosti se lhaním se dostáváme i k tématu morálních prríčin selhání. Horton si je vědom zásadní role, kterou hraje etika v souvislosti s koronakrizí: „Covid-19 není jen krizí zdravotní, je něčím daleko horším ... je krizí samotného života ... virus ukázal na hybris našeho lidského druhu a jeho vlivu na tuto planetu." ${ }^{73} \mathrm{Na}$ jiném místě mluví Horton přímo o nové příležitosti promyslet „etické základy naší společnosti“ a o důležitosti „uctít ztracené životy tím, že budeme žít jinak“.74 Nicméně navzdory morálnímu zaujetí, které se knihou vine jako červená nit, se Horton systematicky etickému selhávání v užším smyslu slova věnuje daleko nejméně. Otázky, které je třeba dle mého názoru v souvislosti s koronakrizí klást a jež si Horton přímo neklade, se týkají specificky západních morálních intuicí: Jaká hodnota je přisuzována životu starších lidí v západních společnostech? Jak velký význam má mezigenerační rodina? Plánujeme život spíše z hlediska dlouhodobého, či je důraz kladen na krátkodobé instantní uspokojení? Nebyla vlažná reakce západních zemí a razantní reakce východních zemí zapříčiněna

70 Horton (2020, s. 92).

71 „The risks we faced, and continue to face, are not only from the new virus. Those risks are also embedded in the system we have created and put in place to review and adjudicate on the threat of pandemic - the regime of science policymaking." Horton (2020, s. 101).

72 „Capitalism has many virtues. But the intense version of capitalism that has emerged over the past forty years has weakened something essential in the social fabric of our societies. Those weaknesses contributed to the tragic toll of deaths. After covid-19 it is no longer acceptable to see people as means rather than ends." Horton (2020, s. 126).

73 Horton (2020, s. 96). Horton zde vychází z prací francouzského antropologa a sociologa Didiera Fassina (2018), dle něhož nemoc není jen biologická záležitost, ale má svůj sociální a politický aspekt (Horton 2020, s. 98).

74 „COVID-19 has provided us with an opportunity to rethink the ethical basis of our society. The virus took so many lives. We can't allow ourselves to return to our old worlds ... To honor the lives lost we have to live differently." Horton (2020, s. 126). 
i tím, že covid-19 zabíjí výrazně častěji především starší lidi? Změnila by se reakce, kdyby zabíjel spíše mladé lidi, jako tomu bylo u španělské chřipky?75

Lze považovat příčiny či faktory vysvětlující selhání některých zemí za kompletní? Domnívám se, že nikoli. Jakkoli lze jen obtížně nesouhlasit s faktory, které identifikuje Horton, je zde i řada dalších vlivů, především faktor př́tomnosti či absence dlouhodobého strategického myšlenív dané společnosti. (Epidemii zvládají lépe země, které na počátku porozuměli tomu, že se jedná o poměrně dlouhodobé riziko v řádu minimálně dvou let a s touto perspektivou hledaly i prostředky $\mathrm{k}$ jejímu zvládnutí; hůře pak země, které uvažují o problémech pouze $\mathrm{v}$ krátkodobém horizontu momentálního zisku a ztráty.) ${ }^{76}$

Horton ani neuvažuje o pojetí, které, zdá se, je vlivné mezi některými českými lékaři, totiž, že průběh epidemie covid-19 je dán primárně biologicky, $\mathrm{v}$ rámci různých společností probíhá téměř shodně, maximálně s časovým posunem, a efektivní dlouhodobá intervence na ochranu populace před patogenem SARS-CoV-2 je nemožná. Ve své naivní podobě se jedná o natolik absurdní stanovisko z hlediska elementárních principů disciplín, jako jsou epidemiologie a veřejné/ globální zdraví, že by je Horton patrně ani nepovažoval za hodné odpovědi. $\mathrm{V}$ revidované podobě, totiž že nefarmakologické intervence jako jsou RRR (ruce, roušky, rozestupy), lockdowny, či TTI (test, trace, isolate) přináší společnosti v nejlepším př́ípadě jen okrajové a dočasné výhody, ovšem daleko větší nevýhody, by se patrně bylo možné tímto stanoviskem zabývat, nicméně Horton tak nečiní. Adekvátní vyvrácení tohoto revidovaného stanoviska přesahuje zaměření tohoto článku, zde pouze konstatuji, že jak v naivní, tak $\mathrm{v}$ revidované podobě je toto stanovisko $\mathrm{v}$ rozporu s vědeckým konsenzem a existuje bohatá odborná literatura, z níž vyplývá jeho neudržitelnost.77

75 To, že západní, na rozdíl od východních společností, reagovaly vlažně na nemoc zabíjející převážně starší osoby, uvádím do souvislosti s důrazem na dưstojnost stáří a mezigeneračních vazeb v čínských (konfuciánských) a budhistických kulturách (Kerles 2020a). Při použití současných experimentálních metod se nicméně zatím tato domněnka př́liš nepotvrzuje, srv. Löckenhoff et al (2015), jakkoli náznaky v její prospěch existují, nejnověji např. v oblasti výzkumu morálních intuicí v oblasti autonomních vozidel, srv. Awad et al (2018).

76 K tomu můj rozhovor, srv. Horák (2020).

$77 \mathrm{~K}$ vědeckému konsenzu srv. Černý et al. (2020) s dalšími odkazy. Teze o primárně biologických faktorech průběhu epidemie je zcela v rozporu s čímkoli, co o epidemiích víme, srv. např. Saracci (2010). Poměrně výstižně charakterizuje epidemii Koubský (2020): „Epidemie rovná se patogen 
Kromě faktorů, které Horton nějakým způsobem identifikuje či rozebírá a které jsem rozčlenil do tř́i skupin (epistemické, politické, etické), je zde i celá doména faktorů, které Horton nezvažuje vưbec, resp. okrajově (např. mluví-li o solidaritě). Tyto faktory lze nazvat jako kulturní, kandidáty by pak mohlo být náboženství, „životní filosofie“, interpretace zdraví a nemoci, apod. ${ }^{78}$ Precizněji zachytit kulturní faktory není snadné, jeden z kulturních faktorů zkoumal tým americké behaviorální psycholožky Michele Gelfandové, totiž přísnost/volnost kultur (tightness/loosness) a jejich zvyklostí. Podařilo se ukázat na zajímavou korelaci, při níž společnosti s vysokou mírou volnosti vykazovaly ve sledovaném období pětinásobné množství případů covid-19. Je ovšem třeba i poukázat na to, že společnosti se srovnatelnou mírou přísnosti/volnosti, např. Švédsko a Thajsko se často výrazně liší z hlediska odpovědi na covid-19, např. co do úmrtnosti pro zmiňované země tisíc dvěstěkrát. To indikuje daleko zásadnější roli dalších faktorů, at již kulturních či jiných. ${ }^{79}$

Zkoumání příčin/faktorů vysvětlujících míru úspěšnosti při ochraně veřejného zdraví té které země či toho kterého civilizačního okruhu, bude patrně živé téma i do budoucnosti. V tomto článku jsem identifikoval tři

(v tomto případě koronavirus SARS-CoV-2) plus chování jednotlivce (péče o vlastní zdraví, hygiena, počet kontaktů...) plus chování a pravidla společnosti (zákazy, omezení, lockdown, ale také převládající životní styl, míra bohatství, politické zřízení, převažující společenská filosofie...). Můžete přičíst ještě čtvrtý člen, prostředí (klima, znečištění...), anebo ho můžete zahrnout do pravidel a fungování společnosti.“ Kromě chování jednotlivce je třeba doplnit ke Koubského charakterizaci i biologické vlastnosti organismu a jeho imunitního systému (v mladší a zdravější populaci může mít epidemie mírnější průběh). V Česku zdůrazňují čistě př́írodní charakter průběhu epidemie covid-19 a nemožnost efektivní intervence na ochranu populace před patogenem SARS-CoV-2 prof. Vladimír Černý a prof. Ladislav Dušek. Pro odkazy na mediální vystoupení prof. Černého, srv. Jedlička (2021).

78 Srv. příspěvky, na kterých jsem se podílel: Mutemwa, M., Zvánovcová, V., Helová, A. \& Novotný, D. D. (2021, v recenzním řízení): „Role of religion, philosophy of life, traditional medicine, and past experiences in Covid-19 pandemic resilience: Zambia case study.“. A dále: Kerles (2020a), Kerles (2020b), Horák (2020).

79 Další kategorie faktorů, které Horton neuvažuje, jsou př́rodního rázu, především klima ageografie. Jakkoli teplé klima i ostrovanství patrně přináší nějaké výhody, nelze je přeceňovat, a je i otázkou, zda by se při pečlivějším globálním komparativním zkoumání nějaká korelace vůbec nalezla. Koronavirus se sice snadněji šiří v chladnějším klimatu, bez problémů ovšem zvládne i šíření v teplém klimatu. Navíc je v zemích s vysokými denními teplotami rozšířena umělá klimatizace, která riziko šíření viru zvyšuje. Podobně i ostrovanství přináší možné výhody při monitoringu hranic před importem nových nákaz, ale i ostrovy jsou lodní a leteckou dopravou často natolik propojeny s jinými zeměmi, že bez cílené zdravotní politiky zabránit importům infekce (např. požadavkem dvoutýdenní karantény) ostrovanství žádné podstatné výhody nepřináší. 
typy důvodů, kterými se alespoň stručně zabývá ve své knize Horton, a poukázal jsem na význam kulturních faktorů, které nijak nezmiňuje. Ani kulturní faktory ovšem nepovažuji za naprosto centrální. Konečné vysvětlení úspěchu některých zemí a selhání jiných bude mít jistě „kompozitní" charakter, tj. žádný jednotlivý faktor či typ faktorů nebude sám o sobě dostačujícím vysvětlením, daný faktor bude ovlivňovat jen do jisté míry. Jeden faktor nicméně považuji za zcela klíčový a domnívám se, že implicitně je prrítomen i v Hortonově přístupu, jak jsem se snažil ukázat i v tomto svém článku. A tím je schopnost rychlého zhodnocení dostupné evidence a volba strategie marginalizace/eliminace. Jen tato strategie totiž může radikálně ochránit zdraví dané populace před devastací novým patogenem s parametry jako je SARS-CoV-2.

Odkud pramení schopnost/neschopnost správné a včasné volby marginalizační strategie? Jedním z důvodů dle mého názoru bude existence kvalitních interdisciplinárních studií veřejného/globálního zdraví v dané zemi a robustnost místních struktur, které vzdělávání v této oblasti předpokládá a spoluvytváří. Bez důvěryhodné epistemické autority v oblasti veřejného/globálního zdraví je totiž vysoce nepravděpodobné, že daná země a její populace bude schopna porozumět fenoménu nové infekční choroby a včas na něj adekvátně reagovat. Kvalitní pandemické plány sice do jisté míry mohou připravit zemi na novou hrozbu, ale tyto plány bez dobrých odborníků, právního zakotvení, nácviku pandemických situací a spolupráce napřrič všemi společenskými vrstvami, zůstanou v krizové situaci jen na papíře.

\section{F. Výhled}

V závěrečných kapitolách Horton stručně podává podněty a návrhy, částečně inspirované i některými filosofy, které by mohly vést ke zlepšení současné situace, a to nejen v západních zemích. Patří mezi ně např̀:

- $\quad$ rozvoj solidarity a sociálního zdraví, při němž jde o celkové zdraví populace; ${ }^{80}$

80 Horton mluví o konceptu ,jednoho zdraví“ (One Health), při němž je zřejmá sounáležitost zdraví jednotlivce a celé populace: solidarity ... mutual respect, mutual concern ... My health depends on your heath. Your health depends on my health. We cannot excape on another. The 
- $\quad$ rozvoj dlouhodobé bdělosti vưči epidemickým rizikům; ${ }^{81}$

- rozvoj „planetárního zdraví; 82

- $\quad$ integrace vědeckého výzkumu a klinické praxe; ${ }^{83}$

- vyvážení svobody slova s adekvátní odpovědí na infodemii;

- harmonizace sledování se svobodou a soukromím. ${ }^{84}$

Především poslední témata, totiž svoboda a ochrana soukromí, je v současném západním diskurzu o koronaviru hojně diskutované. Jak jsem již zmínil v úvodu, existuje rozšířený dojem, že úspěchu při marginalizaci viru dosahují především autoritářské země (ČLR), které na svobodu a soukromí nehledí, zatímco režimy respektující tyto hodnoty jsou neúspěšné. Horton je nicméně přesvědčen, že faktor režimu není zásadní, že např. sledování je možné uvést v soulad i s liberální společností, budou-li zachovány principy jako jsou rovnost, transparentnost, atd. ${ }^{85} \mathrm{~S}$ Hortonovým názorem se ztotožňuji, třebaže jsem si vědom, že téma soukromí a svobody vs. epidemické bezpečnosti

liberties that we prize so highy depend on the health of all of us. ... We are social being. We are political beings. Covid-19 has taught us that we are mutual beings too. ... Covid-19 will change publics: Public will no longer view disease as a pathology of the body. We will see disease as a pathology of society. People will deman stronger systems of health/social protection" Horton (2020, s. 127), srv. také Horton (2020, s. 122) a poznámku č. 82 níže..

81 „Eternal vigilance truly is the price of freedom. We cannot afford to repeat the cycle of crisis, harm, action, complacency, neglect and subsequent vulnerability that followed SARS in 20023." (Horton 2020, s. 110).

$82, \ldots$ the threat this pandemic posed will emphasize the importance of protecting and strenghteing the health of civilizations as well as communities - what we might call our planetary health.“ ... The concept of One health: „health of humans and the health of animals are intricately connected“ Horton (2020, s. 120). Zde by bylo možné doložit výzkumy ohledně ekologických kořenů této epidemie, srv. (Latinne et al. 2020).

83 „Covid-19 will change science: Speedy integration of research into clinical practice, equity and transparency (e.g. in vaccine)..." Horton (2020, s. 122).

84 „How do we reconcile the need for greater surveillance to diminish risks of future pandemic the biopolitical disciplinary society - with a demand to protect the freedoms ... ? Does greater surveillance stand in opposition to our right to privacy?" Horton (2020, s. 108).

85 „I don't fear greater state intrusion into our lives - the panopticonization of society - provided that we insist that this intrusion is guided by some agreed principles, standards and values“ (s. 109). (Horton zde cituje Foucaultovu knihu Biopolitics). Následně Horton stručně vypočítává i morální a právní principy, které je třeba při sledování zachovat: „(1) universality and inalienability - privacy protection must be afforded by everyone, without exception; (2) indivisibility, our rights are interdependent, it is not for the state to determine which rights it will and will not guarantee; (3) equality and non-discriminatory - all human beings are equal in their dignity; (4) transparency - governments must be open about information and their decision-making“" Horton (2020, s. 109). 
je třeba zpracovat daleko podrobněji. Dle některých předběžných studií např. neexistuje korelace mezi demokratičností režimu a úmrtností. ${ }^{86}$ Dokonce bych si dovolil tvrdit opak: dobře fungující země, kde populace spolupracuje $s$ důvěryhodnými odborníky a politiky při ochraně veřejného zdraví, má výhodu oproti zemím s problémovým politickým zřízením. Autoritářské země sice mohou mít dočasné krátkodobé výhody, např. s rychlou organizací uzávěry či s dohledem (surveillance), nicméně z dlouhodobého hlediska je třeba získat k upřímné spolupráci většinu populace, což může být pro autoritářské země problémem.

Hortonovy podněty bude jistě vhodné dále přezkoumat, rozpracovat a případně $\mathrm{v}$ rámci disciplín jako je veřejné/globální zdraví, integrálně začlenit do vzdělávání zdravotníků, nejrůznějších odborníků, politiků, ale $\mathrm{v}$ neposlední řadě $\mathrm{i}$ řadových občanů. $\mathrm{V}$ některých zemích schází porozumění principům ochrany veřejného zdraví nejen politikům či řadovým občanům, ale navíc došlo i $\mathrm{k}$ selhání lékařské profese při vyhodnocení dostupné evidence; i zde bude třeba podniknout nápravu. ${ }^{87}$

Horton vyjadřuje své obavy, že současná koronakrize nepovede k hlubší reformě slabých míst západních společností a že př́ležitosti a hrozby koronakrize zůstanou ležet ladem. ${ }^{88}$ Řešení mnohých dalších globálních problémů (chudoba, hlad, klima, atd.) se zpomalí, USA se i nadále bude stahovat z mezinárodního společenství, dojde k „odmítání Č́ny“", bez níž, navzdory jakýmkoli výhradám, nelze globální problémy

86 Např. dle studie australského libertariánského think-tanku Lowy Institute: Lowy Institute (2021): Covid Performance Index [online]. Dostupný z: https://interactives.lowyinstitute.org/ features/covid-performance/.

87 Bez ohledu na sporné úzké vymezení pojmu „evidence“, které se, jak se zdá, prosadilo v hnutí tzv. „evidence-based medicine“ (srv. Fuller 2020), je zřejmé, že základem medicíny nemá být kvazi-božská autorita člověka (at’ už má sebevětší počet titulů), ale právě evidence (v širokém smyslu slova, tj. zahrnující i potenciální rizika a hrozby). Mnozí lékaři by měli i po padesáti letech vzít vážně výzvu skotského epidemiologa A. L. Cochrana: „In 1972, Professor Archie Leman Cochrane, a Scottish epidemiologist published his book Effectiveness and Efficiency: Random Reflections on Health Services (1972) where he advocated the return to the basic concepts behind evidence-based practice, first formulated by Aristotle (Fig. 10). He criticized the medical profession for much of its practices based on experience rather than evidence ... In many specialties, evidence-based guidelines are continuously being formulated by these bodies and are continuously being updated as new evidence emerges ... It is therefore only appropriate, at this point in time, to remember that evidence-based medicine is in fact a revival of a concept formulated twenty four centuries ago by the great philosopher Aristotle, father of logic." (Sallam 2010).

88 „Along with outbreaks, a recurring pattern of societal amnesia has prevailed. Each microbial challenge has been followed by a period of frenetic activity at every level, internationally and nationally but has concluded with a lapse into forgettfullnes." (Snowden 2020, předmluva k brožované verzi). 
řešit, a v neposlední řadě ztratíme schopnost být šokováni: zvykneme si na umírající lidi, nekompetenci vlád a zneužití moci. Západní společnost se bude organizovat spíše na principu strachu než spolupráce. ${ }^{89}$ Tváŕí v tvář traumatizující zkušenosti zvolíme zapomnění. ${ }^{\circ}$ Zde je třeba říct, že to, jak se dále bude situace vyvíjet, není snadné predikovat, koneckonců historii predikovat nelze, záleží i na našich rozhodnutích. Zde pouze uvádím, že obavy s Hortonem sdílím, přinejmenším pro řadu západních zemí, včetně České republiky. Na druhou stranu je povzbudivé sledovat řadu nezápadních zemí, které naopak řeší epidemii racionálně a v souladu s lidskou důstojností, včetně mnoha zemí asijských a některých afrických.

Hortonova kniha se zabývá protiepidemickou odpovědí západních zemí v první polovině roku 2020. A podobně, jak jsem již zmínil v úvodu, je metodicky zúžena na toto období i tato studie. Změnila se situace vpolovinědruhé, tedy poté, co byla Hortonova kniha publikována? Mnohé západní země sice podnikly některé kroky správným směrem, ovšem převažující strategií i nadále zůstala mitigace, se všemi dlouhodobými nevýhodami zdravotními i hospodářskými, které s sebou tato strategie nese. Rozdíl mezi úspěšnou marginalizační strategií asijských a austrooceánských zemí a neúspěšnou mitigační strategií zemí západních se v druhé polovině roku 2020 jen prohloubil. Ani na konci roku 2020 nedošlo v mnoha západních zemích k jasnému vyhlášení marginalizační strategie, navzdory vědeckému konsenzu, že se jedná o jediný zpo̊sob, jak radikálně chránit veřejné zdraví, ekonomiku i další společenské hodnoty. ${ }^{91}$

89 Horton zde cituje Lars Svendsena, patrně jako varování, totiž že strach je základní organizační princip společností. (Svendsen 2008).

90 „And I worry that we will forget - forget the facts and lessions of COVID-19, just as we forgot the facts and lessons of SARS in 2002-3. Over 300,000 deaths worldwide surely counts as a significant event. In the human story. We should at least consider whether we have an obligation to remember. ... Do we as a global community have an obligation to remember ... as a shared family? I believe we do, partly because this shared memory is what we owe to those who died and partly because we need to remind ourselves what we must do to prevent this avoidable tragedy from repeating itself.“ Zde cituje (Margalit 2002), že „a proper community of memory may help shape a nation“ (Horton, s. 126). K tématu též brilantní komentátor celé koronakrize a jeho závěrečná loňská esej „Where Year Two of the Pandemic Will Take Us As vaccines roll out, the U.S. will face a choice about what to learn and what to forget“ (Yong 2020b).

91 Změnit tuto situaci se snaží pro Evropu např. výzva Priesemann et al. (2020). Srv. taktéž zmiňované The John Snow Memorandum a dokument od The Lancet COVID-19 Commissioners (2020). V ČR think-tank a občanská Inicitiva Sníh (https://www.iniciativa-snih.cz/). 
Bezprecedentně rychlý vývoj účinných vakcín staví země světa koncem roku 2020 do mnohem lepší pozice, jak současnou epidemii řešit. Staví nás ovšem i před nové výzvy. Vakcíny proti onemocnění covid-19 jsou vzácným zdrojem, který je potřeba distribuovat v souladu s uznávanými etickými principy, především spravedlností a transparentností, a současně tak, aby byla alokace tohoto zdroje co nejefektivnější. Jednou $\mathrm{z}$ povinností státu je ochrana veřejného zdraví a sociálního a ekonomického blahobytu a program vakcinace je nedílnou součástí plnění této povinnosti. Vzniká zde tedy celá řada otázek ohledně incentiv na podporu vakcinace a prioritizace při očkování, což jsou vše otázky, které zasahují i do oblasti sociální etiky, politické filosofie a etiky veřejného zdraví. Podaří se včas zajistit náročný proces produkce a distribuce vakcín, aby se život v zemích s aktivními ložisky infekce začal opět podobat životu před epidemií? Podaří se přesvědčit lidi zavalené misinformacemi a dezinformacemi, zvyklé na politické šarvátky i uprostřed boje o život, že očkování je nezbytné?

Hortonova kniha se mnohými otázkami, např. etikou vakcinace, nezabývá. Podobně i některými dalšími důležitými tématy jako je svoboda, které jsem zmiňoval např. v předchozí sekci, se Horton zabývá jen stručně. V souvislosti s hlavní tezí je zde ovšem jedna klíčová otázka, kterou si Horton explicitně neklade, třebaže k jejímu položení text jakoby přímo vybízí, totiž Schuldfrage, tj. otázka zodpovědnosti za selhání. ${ }^{92}$ Kdo je zodpovědný za úspěch či neúspěch při ochraně zdraví obyvatel před pandemií? Společnost jako celek? Stát? Konkrétní osoby? Jedná se o zodpovědnost morální či taktéž právní? Dalších dílčích otázek, které čekají na prozkoumání v souvislosti se Schuldfrage je mnoho. I samotná Hortonova analýza rané fáze koronakrize v západních zemích bude jistě časem doplněna, upřesněna, poopravena. Přesto se domnívám, že zůstane cenným svědectvím jednoho z prvních morálních a věcných pohledů na fenomén epidemie nového koronaviru.

Doufám tedy, že tato recenzní studie je spíše jen jednou z prvních filosofických reflexí koronakrize a další budou následovat. ${ }^{93} \mathrm{Na}$ mnoha

92 Přesněji řečeno, klade si tuto otázku jen okrajově a rétoricky, aby mohl vyvrátit simplistický, dezinformační narativ, že za selhání Západu je primárně zodpovědná ČLR či WHO, srv. např. „So who was responsible for a pandemic that infected 5 milions people and killed over 300,000? China? National goevernments? WHO? Some of the anwers, I think, lie in the lessons from the last outbreak of a SARS virus in 2002-5“ Horton (2020, s. 28).

93 Hortonova kniha byla přijata příznivě, recenze, spíše informačního než polemického rázu, jsem 
místech jsem nechával promluvit autora knihy at’ už přímými citacemi v hlavním textu či v poznámkách pod čarou. I na závěr bych rád ocitoval jednu z výmluvných a výstižných pasáží Hortonovy knihy, které ukazují na potřebu po bolestných zkušenostech s pandemií nepodlehnout pokušení amnézie a naopak tomuto tématu věnovat pozornost i nadále:

„Covid-19 odhalil úžasnou křehkost našich společností, naši sdílenou zranitelnost. Odhalil naši neschopnost spolupracovat, koordinovat a jednat společně. Možná koneckonců nemůžeme ovládat přírodní svět. Možná nejsme tak dominantní, jak jsme si kdysi mysleli. Pokud naplní covid-19 lidskou existenci určitou pokorou, je možné, že budeme nakonec vstřícní vůči lekcím tohoto smrtícího viru. V opačném případě upadneme zpět do naší kultury samolibé výjimečnosti v čekání na další mor, který jistě dorazí.“94

\section{Literatura}

Alwan, N. A. et al. (2020): „Scientific consensus on the COVID-19 pandemic: we need to act now." The Lancet 396 (10260): e71-e72, 31. 10. 2020 DOI: https://doi.org/10.1016/So140-6736(20)32153-X. Úvod a český překlad „Memorandum Johna Snowa: jak na úspěšný boj s Covid-19.“ In Centrum Karla Čapka [online] v sekci Etika epidemie. Dostupné z: https://www.etikaepidemie.cz/clanky/45-memorandum-johna-snowa-jak-na-uspesny-boj-s-covid-19.

Awad, E. et al. (2018): „The Moral Machine Experiment.“ Nature (563): 59-64. Dostupný z: https://www.nature.com/articles/ s41586-018-0637-6.

zaregistroval v časopisech, jako je European Journal of Public Health, Indian Journal of Medical Ethics, Public Understanding of Science, Finantial Times, a Nature. Z obsáhlejších recenzí je třeba zmínit Knight (2020) a Hurley (2020). V době příprav tohoto článku do tisku vyšlo druhé, revidované vydání Hortonovy knihy. Toto vydání jsem zatím neměl k dispozici.“

94 „COVID-19 has revealed the astonishing fragility of our societies, our shared vulnerability. It has revealed our inability to cooperate, to coordinate and to act together. Perhaps we cannot control the natural world after all. Perhaps we are not quite as dominant as we once thought. If COVID-19 eventually imbues human beings with some humility, then possible we will, after all, be receptive to the lessons of this lethal virus. Or perhaps we will sink back into our culture of complacent exceptionalism and await the next plague that will surely arrive." Horton (2020, s. 56-57). 
Balint, J., Strosberg, M., Philpott, S., Baker, R. \& Strosberg, M., eds. (2006): Ethics and Epidemics. Emerald Group Publishing Limited, Bingley.

Battin, M. P. \& Francis, L.P. \& Jacobson, J.A. \& Smith, Ch. B. (2009) The Patient as Victim and Vector: Ethics and Infectious Disease. Oxford: Oxford University Press.

Beck, U. (2004): Riziková společnost: na cestě kjiné moderně. Sociologické nakladatelství, Praha.

Broadbent, A. (2013): Philosophy of Epidemiology. Palgrave Macmillan, London.

Buckley, Ch., Kirkpatrick, D. D., Qin, A. \& Hernández, J. C. (2020): „25 Days That Changed the World: How Covid-19 Slipped China's Grasp." The New York Times [online]. 30. 12. 2020 [cit. 30. 12. 2020]. Dostupné z: https://www.nytimes. com/2020/12/30/world/asia/china-coronavirus.html.

Correia, S., Luck, S. \& Verner, E. (2020): „Pandemics Depress the Economy, Public Health Interventions Do Not: Evidence from the 1918 Flu. " DOI: http://dx.doi.org/10.2139/ssrn.3561560.

CSARIM, CSIM. (2020): Opatření vedoucí ke snižování vnímavosti populace vůči onemocnění covid-19 (tzv. přirozená imunizace)."In Česká společnost intenzivní medicíny [online]. 13. 4. 2020 [cit. 31. 12. 2020]. Dostupné z: https://csim.cz/wp-content/uploads/2020_PP_07_CSARIM_CSIM_COVID_pasivni_imunizace_final_120420_oprava-1.pdf.

Cyranoski, D. (2020): „The biggest mystery: what it will take to trace the coronavirus source." Nature, 5. 5. 2020. Dostupný z: https://www.nature.com/articles/d41586-020-01541-z.

Černý, D., Novotný, D. \& Jedlička, P. (2020): „Jak na úspěšný boj s koronavirem: Memorandum Johna Snowa: vědecký konsensus k pandemii covid-19." Tempus medicorum 29 (12): 8-9.

Delvaux, J. \& Rajan, S. (2020): „Covid-19 \& Philosophy: Towards a Bibliography." [online]. Dostupný z: https://docs.google.com/document/d/15YkfraGX4wNRUmg3M4WHCyZjLxcbnCmLtZ-YggcKTXY/edit [cit. 30. 12. 2020]. 
Dowdle, W. R. (1998): „The principles of disease elimination and eradication." Bulletin of the World Health Organization 76 (Suppl. 2): 22-25. Dostupný z: https://www.ncbi.nlm.nih.gov/pmc/articles/ PMC2305684/.

Dzúrová, D. \& Jarolímek, J. (2020): Šíření pandemie COVID-19 např́č geografickými i sociálními hranicemi: dokážeme mu čelit? Geografie 125 (1): 1-20. DOI: https://doi.org/10.37040/geografie2020125010001.

Evanega, S., Lynas, M., Adams, J. \& Smolenyak, K. (2020): „Coronavirus misinformation: quantifying sources and themes in the COVID-19 ,infodemic'." (Preprint). Dostupný z: https://www.uncommonthought.com/mtblog/wp-content/uploads/2020/12/Evanega-et-al-Coronavirus-misinformation-submitted_07_23_20-1.pdf.

Fassine, D. (2018): Life. A Critical User's Manual. Polity Press, Cambridge, UK, Medford, MA.

Fidler, D. (2004): SARS, Governance and the Globalization od Disease. Palgrave Macmillan, Basingstoke.

Fuller, J. (2020): „Modely versus evidence.“ In Centrum Karla Čapka [online]. Článek převzat z Boston Review, 20. 5. 2020, český překlad Martin Zach. [cit. 31. 12. 2020]. Dostupný z: https://www. etikaepidemie.cz/clanky/46-modely-versus-evidence.

Gans, J. (2020): The Pandemic Information Gap: The Brutal Economics of COVID-19. MIT Press, Cambridge, MA.

Gelfand, M., Jackson, J. C., Pan, X., Nau, D., Pieper, D., Denison, E., Dagher, M., Van Lange, P., Chiu, Ch. \& Wang, M. (2021): „The relationship between cultural tightness-looseness and COVID-19 cases and deaths: a global Analysis." The Lancet Planetary Health 5 (3). DOI: https://doi.org/10.1016/S2542-5196(20)30301-6. Green, M. S., Swartz, T., Mayshar, E., Lev, B., Leventhal, A., Slater, P. E. \& Shemer, J. (2002): „When is an epidemic an epidemic?“ The Israel Medical Association Journal 4 (1): 3-6.

Holub, P. (2020): Koronavirus: Falešný poplach. Echo media, Praha. Horák, O. (2020): „Filozof o korone: Reagujeme len na momentálne riziko, Európe chýba dlhodobý plán.“ Rozhovor s D. D. Novotným. 
Deník N [online]. 7. 11. 2020. [cit 8. 11. 2020]. Dostupný z: https://dennikn.sk/2125708/filozof-o-korone-reagujeme-len-na-momentalne-riziko-europe-chyba-dlhodoby-plan/.

Horton, R. (2003): Second Opinion: doctors, diseases and decisions in modern medicine. Granta Books, London.

Horton, R. (2020): The Covid-19 Catastrophe: What's Gone Wrong and How to Stop it Happening Again. Polity, Cambridge.

Honigsbaum, M. (2020): The Pandemic Century. A History of Global Contagion from the Spanish Flu to Covid-19. Penguin, Cambridge, MA.

Huntington, S. (2001): Střet civilizací, boj kultur a proměna světového řádu. Rybka publishers, Praha.

Hurley, Z. (2020): „Review of Richard Horton (2020): The Covid-19 Catastrophe: What's Gone Wrong and How to Stop it Happening Again." Postdigital Science and Education 2 (3): 1015-1019, 27. 7. 2020. DOI: 10.1007/s42438-020-00171-y.

Christakis, N. (2020): Apollo's Arrow: The Profound and Enduring Impact of Coronavirus on the Way We Live. Little Brown Spark, New York.

Jedlička, P. (2021): „Personální okénko: Vladimír Černý, architekt ,českého řešení، "In Facebook - Petr Jedlička [online]. 27. 2. 2021 [cit. 2. 3. 2021]. Dostupné z: https://www.facebook.com/login/?next=https\%3A\%2F\%2Fwww.facebook.com\%2Fpetrjedlicka100\%2Fposts\%2F10225845478423207.

Jones, K., Patel, N., Levy, M., Storeygard, A., Balk, D., Gittleman J. L. \& Daszak, P. (2008): „Global trends in emerging infectious diseases." Nature 451: 990-993. DOI: https://doi.org/10.1038/natureo6536.

Kerles, M. (2020a): „Jsme svědky experimentu s lidmi. Jeho dosah si mnozí nedovedou ani představit, rríká Novotný." Info.cz [online]. Rozhovor s D. D. Novotným. 18. 03. 2020. Dostupný z: https://www.info.cz/cesko/jsme-svedky-experimentu-s-lidmi-jeho-dosah-si-mnozi-nedovedou-ani-predstavit-rika-novotny-44614. html.

Kerles, M. (202ob): „Druhou vlnu covidu si vyrábíme sami, ř́ká filozof Novotný.“ Info.cz [online]. Rozhovor s D. D. Novotným. 24. 07. 
2020. Dostupný z: https://www.info.cz/zpravodajstvi/cesko/covid19-rozhovor-novotny.

Kerles, M. (2020c): „Západ v boji s koronavirem zvolil horší taktiku. A zbytečně obětoval tisíce životů, říká filozof Novotný." Info. cz [online]. Rozhovor s D. D. Novotným. 21. 10. 2020. Dostupný z: https://www.info.cz/zpravodajstvi/cesko/zapad-v-boji-s-koronavirem-zvolil-horsi-taktiku-a-zbytecne-obetoval-tisice-zivotu-rika-filozof-novotny.

Knobler, S., Mahmoud, A., Lemon, S., Mack, A., Sivitz, L. \& Oberholtzer, K., eds. (2004): Learning from SARS: Preparing for the Next Disease Outbreak. National Academic Press, Washington. Knight, S. (2020): „The Lancet editor's wild ride through the coronavirus pandemic." The New Yorker [online]. 27. 6. 2020 [cit. 8. 11. 2020]. Dostupný z: https://www.newyorker.com/news/letter-from-the-uk/the-lancet-editors-wild-ride-through-the-coronavirus-pandemic.

Koubský, P. (2020): „Rok covidu očima Petra Koubského: Můžeme si lehnout a rozplakat se. Lepší je ale vstát, číst a pochopit.“ Deník $N$ [online]. 22. 12. 2020 [cit. 25. 12. 2020]. Dostupný z: https://denikn.cz/521923/muzeme-si-lehnout-a-rozplakat-se-lepsi-je-ale-vstat-cist-a-pochopit-rok-covidu-ocima-petra-koubskeho/.

Křepelka, F. (2020): „Právo pandemie covidu-19: náčrt celkového obrazu. " Časopis zdravotnického práva a bioetiky 10 (2): 1-70.

Kulveit, J. (2021): „Debata v Česku je i obětí vědeckých omylů. A o joaniditech." [online] [cit. 27. 2. 2020]. Dostupný z: https://boundedlyrational.substack.com/p/debata-v-esku-je-i-obt-vdeckch-omyl.

Kucharski, A. (2020): The Rules of Contagion. Why Things Spread and Why They Stop. Baci Books, New York.

Latinne, A., Hu, B., Olival, K. J. et al. (2020): „Origin and cross-species transmission of bat coronaviruses in China." Nature Communications 11. DOI: https://doi.org/10.1038/s41467-020-17687-3. Lennox, J. (2020): Where Is God in a Coronavirus World? Epsom, UK, Good Book Company. 
Löckenhoff, C., Lee, D., Buckner, K., Moreira, R., Martinez, S. \& Sun, M. (2015): „Cross-Cultural Differences in Attitudes About Aging: Moving Beyond the East-West Dichotomy." In Successful Aging: Asian Perspectives, eds. Cheng, S-T., Chi, I., Fung, H., Li, L., \& Woo, J., Springer, Dordrecht, s. 321-337. DOI: 10.1007/97894-017-9331-5_19.

MacKenzie, D. (2020): Covid-19: The Pandemic that Never Should Have Happened, and How to Stop the Next One. Hachette Books, New York.

Mallapaty, S., Maxmen, A. \& Callaway, E. (2021): „Major stones unturned': COVID origin search must continue after WHO report, say scientists.“ Nature 590: 371-372. DOI: https://doi. org/10.1038/d41586-021-00375-7.

Margalit, A. (2002): The Ethics of Memory. Harvard University Press, Cambridge, MA.

Martin, P. M. \& Martin-Granel, E. (2006): „2,500-year evolution of the term epidemic." Emerging Infectious Diseases 12 (6): 976-980. DOI: doi:10.3201/eid1206.051263.

Miller, J. ed. (2020): The Coronavirus: Human, Social and Political Implications. (C) 2020, Palgrave MacMillan, Singapore.

Ord, T. (2020): The Precipice: Existential Risk and the Future of Humanity. Hachette Books, New York.

Philips, N. (2021): „The coronavirus is here to stay - here's what that means." Nature 590: 382-384, 16. 2. 2021. DOI:

https://doi.org/10.1038/d41586-021-00396-2.

Priesemann, V. et al. (2021): „Calling for pan-European commitment for rapid and sustained reduction in SARS-CoV-2 infections." The lancet 397 (10269): 92-93, 9. 1. 2021, publikováno 18. 12. 2020. DOI: https://doi.org/10.1016/So140-6736(20)32625-8.

Quammen, D. (2012): Spillover: Animal infections and the next human pandemic. W. W. Norton \& Company, New York.

Rabadán, R. (2020): Understanding Coronavirus. Cambridge University Press, Cambridge.

Rothman, K. J., Greenland, S. \& Lash, T. L. (2008): Modern Epidemiology. Third Edition. Lippincott Williams \& Wilkins, Philadelphia. 
Sallam, H. N. (2010): „Aristotle, godfather of evidence-based medicine." Facts, views \& vision in ObGyn 2 (1): 11-19.

Saracci, R. (2010): Epidemiology: A Very Short Introduction. Oxford University Press, Oxford.

Schwartz, M. C., ed. (2020): The Ethics of Pandemics. Broadview Press, Peterborough, ON.

Simiao, Ch. et al. (2020): „Fangcan shelter hospitals: a novel concept for responding to public health emergencies." The Lancet 395 (10232): 1305-1314. 18. 4. 2020, elektronicky 2. 4 2020. DOI: 10.1016/So140-6736(20)30919-3.

Snowden, F. M. (2019): Epidemics and Societies: From the Black Death to the Present. Yale University Press, New Haven; brožované vydání s novou předmluvou Yale University Press, New Haven, 2020.

Svendsen, L. (2008): A Philosophy of Fear. Reaktion Books, London.

Šejvl, M., Agha, P., Sobek, T., Kokešová, J. \& Černý, D. (2020): Vítězove a poraženi': Práuni' a etické problémy současne' koronakrize. Ústav státu a práva AV ČR, Praha.

The Lancet COVID-19 Commissioners (2020): „Lancet COVID-19 Commission Statement on the occasion of the 75th session of the UN General Assembly." The Lancet 396 (10257): 1102-1124, 10.10. 2020, elektronicky 14. 8. 2020. Dostupný z: https://www.thelancet.com/journals/lancet/article/PIISo140-6736(20)31927-9/fulltext.

Walter-Toews, D. (2020): On Pandemics: Deadly Diseases from Bubonic Plague to Coronavirus New Edition. Greystone Books, Vacouver.

Wayne, M. L. \& Bolker, B. B. (2015): Infection Disease: A Very Short Introduction. OUP, Oxford.

WHO (2020): Report of the WHO-China Joint Mission on Coronavirus Disease 2019 (COVID-19) In World Health Organization. [online]. 16.-24. 2. 2020. Dostupný z: https://www.who.int/docs/ default-source/coronaviruse/who-china-joint-mission-on-covid-19-final-report.pdf.

Yong, E. (2020a): „Why the Coronavirus Is So Confusing: A guide to making sense of a problem that is now too big for any one per- 
son to fully comprehend." The Atlantic [online]. 29. 4. 2020. Dostupný z: https://www.theatlantic.com/health/archive/2020/04/ pandemic-confusing-uncertainty/610819/.

Yong, E. (2020b): „Where Year Two of the Pandemic Will Take Us As vaccines roll out, the U.S. will face a choice about what to learn and what to forget." The Atlantic [online]. 29. 12. 2020. Dostupný z: https://www.theatlantic.com/health/archive/2020/12/pandemic-year-two/617528/.

Žižek, S. (2020): Pandemic! Covid-19 Shakes the World. OR Books, New York.

\section{Abstract}

\section{The Covid-19 Catastrophe: On the book of Richard Horton}

In this review study, I reflect on Richard Horton's book and his thesis that Western countries failed in their response to the current epidemic in the first half of 2020, with a few exceptions. In the five sections of the paper, after an initial modification of Horton's thesis (A), I discuss briefly: suppression approach in China (B), mitigation approach in the West (C), the SARS epidemic as the key global public health event (D), the causes of West failure (epistemic, political, ethical, cultural, etc.) (E), and final envoi (F).

Key word: epidemic ethics, covid-19, public health, health policy, West

Novotný, D. D. (2020): „Covid-19 katastrofa: Nad knihou Richarda Hortona.“ Filosofie dnes 12 (2): 88-127. Dostupné z www.filosofiednes.ff.uhk.cz 


\section{ČASOPIS}

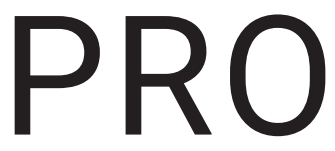

SOUČASNOU

FILOSOFII 